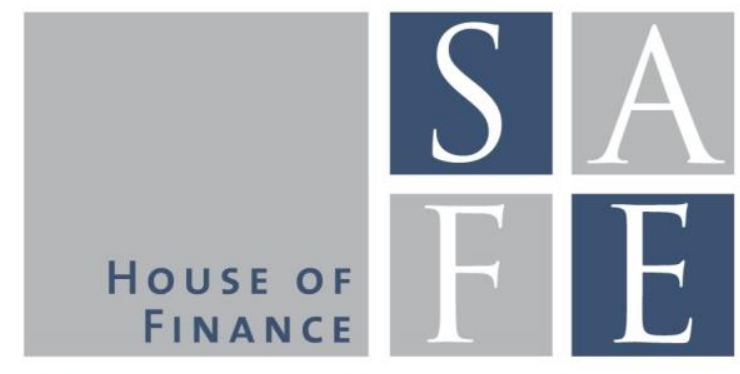

WORKING PAPER SERIES

Steffen Meyer - Linda Urban - Sophie Ahlswede

\title{
Does feedback on personal investment success help?
}

SAFE Working Paper No. 157

SAFE I Sustainable Architecture for Finance in Europe A cooperation of the Center for Financial Studies and Goethe University Frankfurt 


\section{Non-Technical Summary}

Private investors make costly investment mistakes. Cronqvist and Siegel (2014) show that genetic predispositions can explain up to $45 \%$ of investment mistakes. The remaining $55 \%$ can be attributed to factors, such as experience, circumstances, or events. This finding implies that the behavior of investors is not deterministic and may in principle be affected by training or information, due to which in turn investors may learn how to avoid their mistakes.

Research has tested several potential solutions in order to devise remedies for investment mistakes. Studies of these remedies show mixed to disappointing outcomes in terms of improved investment decisions. Examples include studies providing simplified information on investment products and studies based on providing financial advice, such as in Beshears et al. (2009), Bhattacharya et al. (2012) or Hackethal et al. (2012). While these strands of research have been studied extensively, the provision of feedback on investment performance, trading costs and diversification has not received much attention yet.

Most banks do not provide private investors with feedback on their investment decisions or use of banks' brokerage services. A survey conducted in Germany shows that only 1 out of 120 banks regularly informed a small group of their customers about the risk, return and costs of their portfolios over the previous year, see Stiftung Warentest (2013). All other financial services providers fulfill only their statutory duties and provide information on holdings, volumes, current market-prices, the position value and in some case the purchase price of the position. There is no information on the portfolio except for its current total value.

We test in a field experiment if feedback on risk, return, costs, and portfolio diversification contributes to improving investment decisions. We design four different one-page reports by drawing on findings from research on decision-making and behavioral economics and randomly assign clients to the different report designs. Over an eighteen-month period we provide more than 1,500 investors with feed back on the development of their securities account, their returns, trading costs and risk-levels as well as their level of diversification.

Our results in this field experiment support the view that providing investors with "postcontractual" feedback on their portfolio helps them improve investment decisions. We use investors' real investment accounts and a difference-in-differences setting using a propensity score matched sample to test the impact of our reports on their investment activity. We find that, after receiving reports, investors trade less, diversify more and have a higher risk-adjusted performance relative to the control group. These effects become stronger over time. Results are robust to potential outliers and are not driven by information overload. The results are neither driven by attrition nor by the time when investors register for receiving reports.

We find that effects do not differ much between the different report designs. It seems that it is more important to provide investors with relevant feedback, rather than a specific format in which it is delivered. The reports containing peer information do not seem to be particularly useful to investors. This finding also suggests that the reports induce the change but are likely not the only source of investors' improved decisions. 
One may conclude that all our reports do is raise investors' attention. If the reports simply raised attention, the existing literature suggests that trading should increase and performance deteriorate, see Barber and Odean (2008) and Gerhardt and Meyer (2013). However, we observe the opposite. Furthermore, awareness and attention would not explain why results become stronger over time. Hence, at least part of the results seems to be induced by the reports themselves rather than only by directing investors' attention towards their account.

Our study shows that the introduction of a regular securities account reporting helps online brokerage customers. Can we infer that it may also help the average stock market participant? As our results do not change if we focus on the very literate investors only, we believe this might be the case. To test whether the reports would benefit also less sophisticated and less active investors, we separate our sample into two subgroups according to investors' likelihood to subscribe to our report. We find that both subgroups would equally benefit from the reports. Therefore, if shrouding was present in household investing and an implicit wealth transfer from sophisticated to less sophisticated investors took place, this study suggests that feedback could be part of a solution. There is no incentive in the market to overcome shrouding and our results suggest that it may not be in the broker's interest to provide feedback to investors as they ultimately start trading less. In any case, the provision of this kind of feedback is costly and difficult to gather and edit, not only for the investor herself but also for any third party. Therefore, it might be worth considering a policy intervention. 


\title{
Does feedback on personal investment success help?
}

\author{
Steffen Meyer, Linda Urban, Sophie Ahlswede*
}

\begin{abstract}
In a field study with more than 1.500 customers of an online-broker we test what happens when investors receive repeated feedback on their investment success in a monthly securities account report. The reports show investors' last year's returns, costs, their current level of risk and their portfolio diversification. We find that receiving a report results in investors trading less, diversifying more and having higher risk-adjusted returns. Results are robust to controlling for potential play money accounts and changes in report designs. We also find that investors who are less likely to subscribe equally benefit from the report.
\end{abstract}

JEL classification: D14, G11, G28

Keywords: household finance, field study, individual investors, reporting, investment mistakes, regulation

\footnotetext{
* Meyer (meyer@gif.uni-hannover.de) is affiliated with Leibniz Universität Hannover, Urban and Ahlswede are affiliated with Goethe University Frankfurt am Main. Sophie Ahlswede is now employed by the European Securities and Markets Authority and Linda Urban is employed by Fidor Bank. For helpful comments we thank Roman Inderst, Joachim Weber, Andreas Hackethal, Helmut Gründl and participants at the European Retail Investment Conference 2015 in Stuttgart.
}

This research would not have been possible without the collaboration of a German bank. Goethe University Frankfurt gratefully acknowledges financial support and provision of data from this bank. We thank this bank and all its employees who helped us.

We gratefully acknowledge research support from the Research Center SAFE, funded by the State of Hessen initiative for research LOEWE

The views expressed in this paper are those of the authors and do not necessarily reflect the views of the European Securities and Markets Authority or Fidor Bank. 


\section{Introduction}

Private investors make costly investment mistakes ${ }^{1}$ and their ability to learn from past mistakes seems limited (Brad M. Barber, Terrance Odean, and Lu Zheng 2005). Where research documents learning of investors, it is mainly driven by attrition (Amit Seru, Tyler Shumway, and Noah Stoffman 2010) or by the presence of information which is made salient to investors, e.g. front-end loads (Barber, Odean, and Zheng 2005) or overdraft fees (Victor Stango and Jonathan Zinman 2014). Henrik Cronqvist and Stephan Siegel (2014) show that genetic predispositions can explain up to $45 \%$ of investment mistakes. The remaining $55 \%$ or more can be attributed to experience, circumstances, events and other factors. This finding implies that the behavior of investors is not deterministic and may in principle be affected by training or information.

Research has tested several potential solutions in order to devise remedies for investment mistakes as demanded by John Y. Campbell (2006). Studies of these remedies show mixed to disappointing outcomes in terms of improved investment decisions. Examples include studies providing simplified information on investment products (e.g. John Beshears et al. 2009), and studies based on providing financial advice (e.g. Utpal Bhattacharya et al. 2012; Andreas Hackethal, Michael Haliassos, and Tullio Jappelli 2012). While these strands of research have been studied extensively, the provision of feedback on investment performance, trading costs and diversification has not received much attention yet.

Most banks do not provide private investors with feedback on their investment decisions or use of banks' brokerage services. A survey conducted in Germany shows that only one in 120 banks regularly informs a small group of their customers about the risk, return and costs of their portfolios over the previous year (Stiftung Warentest (Ed.) 2013). All other financial services providers fulfill only their statutory duties and provide information on holdings, volumes, current market-prices, the position value and in some case the purchase price of the position. There is no information on the portfolio except for its current total value. In theory,

\footnotetext{
1 There is an extensive body of literature with respect to investment mistakes. Therefore, we highlight a few examples. Among these are overconfidence (Nicholas Barberis, Andrej Shleifer, and Robert W. Vishny (1998); Kent Daniel, David Hirshleifer, and Avanidhar Subrahmanyam (1998); Terrance Odean (1998, 1999), Brad M. Barber and Terrance Odean (2000, 2001)), underdiversification (Marshall Blume and Irwin Friend (1975); Daniel Dorn and Gur Huberman (2005); John Y. Campbell (2006); Laurent E. Calvet, John Y. Campbell, and Paolo Sodini (2007); William N. Goetzmann and Alok Kumar (2008)), loss aversion (Shlomo Benartzi and Richard H. Thaler (1995); Nicholas Barberis and Ming Huang (2001)), the disposition effect (Terrance Odean (1998); Hersh Shefrin and Meir Statman (1985); Martin Weber and Colin F. Camerer (1998)), and local and home bias (Kenneth R. French and James Poterba (1991); Karen K. Lewis (1999); Zoran Ivkovic and Scott Weisbenner (2005)).
} 
investors could at least partly calculate their portfolio performance and costs from this feedback they receive from their bank. However, the costs of doing so are relatively high for the individual. John Y. Campbell et al. (2011) note that providing consumers with the necessary information represents a coordination problem that may be most efficiently solved by requiring financial services providers to provide that information to their clients.

We test in a field experiment whether feedback on risk, return, and costs as well as portfolio diversification contributes to improving investment decisions. Our findings are as follows: After receiving reports investors trade less, diversify more and have a higher riskadjusted performance relative to the control group. We use investors' real investment accounts. Investors receive individual reports every month and we study the effect for the data available after 18 months. We design four different one-page reports by drawing on findings from research on decision-making and behavioral economics and randomly assign clients to the different report designs. All reports contain information on performance, costs, risk levels and diversification. Some reports contain peer information of other investors' portfolios in the same risk category as the respective investor.

We evaluate the effects of receiving a securities account report in a difference-indifferences (DiD) setting using a propensity score matching. We test the effects after 12 and 18 months and find that effects become stronger over time. Results are robust to potential outliers and are not driven by information overload, as the effects do not depend on the very financially literate investors only. The results are neither driven by attrition nor by the time when investors register for receiving reports. We also find that investors who receive a report and trade within 5 days show slightly stronger effects.

We find that effects do not differ much between the different report designs. It seems that it is more important to provide investors with relevant feedback, rather than a specific format in which it is delivered. The reports containing peer information do not seem to be particularly useful to investors. This is in line with recent research of John Beshears et al. (2011b) who find differences in the way peer effects work depending on subjects' relative characteristics. This finding also suggests that the reports induce the change but are likely not the only source of investors' improved decisions. One may conclude that all our reports do is raise investors' attention. If the reports simply raised attention, the existing literature suggests that trading should increase and performance deteriorate (Brad M. Barber and Terrance Odean 2008; Ralf Gerhardt and Steffen Meyer 2013). However, we observe the opposite. Furthermore, awareness and attention would not explain why results become stronger over time. Hence, at 
least part of the results seem to be induced by the reports themselves rather than only by directing investors' attention towards their account.

Our study shows that the introduction of a regular securities account reporting helps online brokerage customers. Can we infer that it may also help the average stock market participant? We believe it might. First, our results do not change if we focus on the very literate investors only. ${ }^{2}$ Second, our reports could help regular stock market participants, who often do not know their costs, diversification and performance (Markus Glaser and Martin Weber 2007). The reports would send a salient signal on investors' own or their advisors trading skills and potentially reduce the profitability of misselling (Roman Inderst and Marco Ottaviani 2009). In order to test whether the reports would benefit also less sophisticated and less active investors, we separate our sample into two subgroups according to investors' likelihood to subscribe to our report. We find that report receivers that are less likely to subscribe and less financially literate show similar improvements in their investment behavior as those who are more likely to subscribe.

In terms of empirical studies we are aware of two related studies. The first one examines the influence of peer information on participation in capital markets (Beshears et al. 2011b), and the second one studies how a one-time feedback on the previous month's performance affects investors decisions (Bhattacharya et al. 2012; Gerhardt and Meyer 2013). John Beshears et al. (2011b) find that the usefulness of peer-information depends on investor characteristics, that reports are generally read and that investors trade after receiving them. In their setting they do not find any changes in behavior. In contrast, a model from microeconomic theory by Emir Kamenica, Sendhil Mullainathan, and Richard Thaler (2011) shows that providing customers with information on their use of services would allow them to optimize their decision-making.

The structure of this paper is as follows: We describe the field study in chapter II. Chapter III elaborates on the data and in chapter IV we discuss the identification strategy to measure the impact of the reports on investor behavior as well as key metrics. Chapter V presents and discusses the results and chapter VI concludes.

\footnotetext{
${ }^{2}$ Unfortunately, our sample is relatively homogeneous in terms of financial literacy and there are not enough less literate investors to explicitly test effects for those investors.
} 


\section{The Field Study}

\section{II.I. Experimental set-up of the field study}

We carry out our experiment with a German online broker that serves more than 100,000 clients and is not authorized to offer advisory services to clients.

In order to retain existing customers and attract new ones, the broker set out to introduce a personalized securities account reporting to clients. The reports are not available in real-time, but are made available to customers around the $15^{\text {th }}$ day of the following month, incorporating all information available until the end of the preceding month. For example, the report made available on 15 July 2014 takes into account all information available until 30 June 2014.

To attract subscribers to the securities account reporting service the broker put up banner ads on its website. These ads were clearly visible to anyone accessing the website. By clicking on the banner ad clients were routed to a landing page, which provided them with details on the offer. Clients were informed that the service was perpetual and free of charge. Additionally, they learned that Goethe University's House of Finance provided academic expertise and advice on the development of the report. However, they were not aware they were part of an experiment. Therefore, our study qualifies as a "natural field experiment" following Glenn W. Harrison and John A. List (2004).

From the landing page, interested clients could log in to take part in a survey. The reason for this pre-report survey was to obtain investors' consent to use their account data and obtain legal permission to send them the report. ${ }^{3}$ In addition, we also collected information on investor demographics, investment goals and risk-capacity. This approach of creating a sample of reportreceivers may create self-selection issues which we address later when we discuss the identification strategy.

From January 2013 until the first report was sent in August 2013678 investors with a total of 783 securities accounts registered as participants. The survey remained online for further registration after the experiment had gone live. Figure 1 provides an overview of the number of new investment accounts being registered for receiving reports.

[INSERT FIGURE 1 ABOUT HERE]

Finally, the broker provided us with anonymized securities account data including all

\footnotetext{
${ }^{3}$ Without such permission, sending out the reports would have been considered unsolicited commercial material. To increase the number of subscribers we offered a lottery among those who sign up. The five winners of the lottery were drawn in July 2013 before the first report was made available and received a gold bar worth $200 €$ at the time of the lottery.
} 
transactions at the single investor level for three years prior to the start of the field experiment for all customers that signed up for the report as well as for a random sample of approximately 35,000 customers whose (aggregated) data is used for computing the peer-group information.

\section{II.II. Report design}

Characteristics of the investor, the recipient of information, determine how that information is perceived: The ability to process information increases with the investor's knowledge in the respective area (Joseph W. Alba and J. W. Hutchinson 1987) or the ease with which the investor acquires information (J. E. Russo et al. 1986). At the same time, the number of different informational items that an investor can process at once is limited (George A. Miller 1956). More information potentially leads to poorer quality decisions (Mark I. Hwang and Jerry W. Lin 1999). On the other hand, it can be dangerous to present an incomplete set of information: Any information that is not part of the report may be considered irrelevant or not considered at all for subsequent investment decisions (Nicholas H. Lurie and Charlotte H. Mason 2007). Therefore, the following three questions must be addressed: 1 . What information to convey to customers? (content) 2. How to convey this information to customers? (format) and 3. How often to provide the information? (frequency).

\section{i. Report content}

In order to determine the content we prioritize the most costly investment mistakes identified by existing literature. We pick two investment mistakes, which have been shown to impede the efficiency of private investor portfolios: underdiversification and overtrading. In relation to underdiversification, the literature indicates that investors hold portfolios with high idiosyncratic variance shares (Laurent E. Calvet, John Y. Campbell, and Paolo Sodini 2007) or have a home and/or local bias (Kenneth R. French and James Poterba 1991; Karen K. Lewis 1999; Zoran Ivkovic and Scott Weisbenner 2005). William N. Goetzmann and Alok Kumar (2008) argue that underdiversification is associated with a return loss of $2 \%$. In relation to overtrading, the literature argues that private investors are overconfident, and buy and sell stocks too frequently and consequently do not benefit from their trading (Odean 1998, 1999; Barber and Odean 2001). Brad M. Barber and Terrance Odean (2000) report a return loss of 5\% for net returns. Joachim Weber et al. (2014) study a large sample of German investors and show that the identified costs of underdiversification and overtrading were within the same range in that country. 
For our study, the reports show portfolio-level information rather than individual positions because asset allocation contributes to investment success more than stock selection (Gary P. Brinson, L. R. Hood, and Gilbert L. Beebower 1986) and most of the investment biases can only be recognized at the portfolio level.

\section{ii. Report format}

Regarding the format, we consider findings from different relevant research areas, including behavioral economics, neuro-finance, (financial) decision making, feedback and learning, risk perception, and information disclosure. To arrive at the final design of the reports we follow a three-step process. We first design potential graphical displays, then discuss these potential displays with two focus groups and decide on final reports based on these discussions. All reports contain information on risk, return and transaction costs. Reports 2-4 also contain information on asset allocation and diversification. The main differences between the four reports are: The first report design resembles the one used by Ralf Gerhardt and Steffen Meyer (2013) but instead of the last month it shows information on performance and risks for the previous twelve months. As already outlined above we exclusively focus on the portfolio perspective and do not provide information on single securities. Reports 2-4 contain the same basic information on the investor's portfolio but the graphical displays differ from Report 1 . While Report 1 shows the number of trades per month during the last year, Reports 2-4 show trading costs over the last year. The information is equivalent since the broker has a flat fee for most securities. Report 1 shows risk in a volatility-return scatter plot comparing the investors' portfolio to different indices. Reports 2-4 all use three ways to show risk: a) with a fan chart showing the volatility of the portfolio development, b) with a stacked bar chart showing diversification across nine asset classes and c) a pie chart showing the share of unsystematic risk relative to systematic risk. Report 2 compares the performance of investors with the performance of the index MSCI World. Report 3 additionally contains peer information, i.e. information on outcomes of other investors with the same risk level as the respective investor that receives the report. Report 4 also contains peer information and an additional executive summary text.

\section{iii. Report frequency}

Regarding frequency previous research by Uri Gneezy and Jan Potters (1997) shows that too frequent information may increase risk aversion. In contrast, John Beshears et al. 
(2011a) show that the frequency of information does not systematically bias investors if decision environments are close to reality. As we are working with real portfolios we believe that their finding applies to our study. We therefore opt for a monthly frequency to send reports covering the respective previous year. Our choice of frequency is also based on two other reasons: First, investors in Germany are used to receiving invoices and information on the usage of services on a monthly basis. For example, current account statements, telephone bills, credit card bills as well as rent payments are normally subject to a monthly frequency. Second, the focus groups also favored receiving reports once a month. More information on the detailed motivation for different content, formats and frequencies are summarized in the appendix to this paper.

Data

The broker provides account holdings for each end-of-month, transactions during the month, as well as the investors' cash holdings, together with demographic information collected in the account opening process. We complement the investor data with market data for the more than 350,000 different securities traded by the investors over the time horizon of the experiment. These daily market data are from Thomson Reuters Datastream and cover 78\% (value weighted) of the required universe. If a security is missing in Datastream we use month-end values as well as intra-month trading prices to interpolate a time series.

The broker provides the data for three years prior to the start of the field experiment for the participants as well as for a random sample of approximately 35,000 investors whose data is used to calculate peer group data. From the information provided by the broker we calculate for each investor their total portfolio size, portfolio return, turnover, age and sector of employment.

For those who register to receive a report and answer our survey we gain responses to 32 questions on additional demographics, investment goals, investment behavior, and performance. The information from the survey is used to categorize investors into a risk category, which is shown to them during the survey. The categorization is based on European Commission Regulation No 583/2010. However, instead of seven risk categories we group investors into ten categories. Category one is for the most risk-averse and 10 for the least riskaverse investors. Investors may overrule the risk category we suggest to them based on their answers. If investors do not finish the questionnaire a risk category of five is set by default. The investor can change this risk category at any time via a link incorporated in every securities account report. This actually barely happens. 
In total, from January 2013 until the first report was sent in August 2013, 678 customers of the broker with a total of 783 securities trading accounts filled in the survey. The survey remained online for further participation after August 2013 when the experiment went live. Until the end of January 2015 investors with 1,612 securities accounts answered the questionnaire and started receiving securities account reports.

Table 1 contains an overview of the average characteristics of subscribers and nonsubscribers. The reference date for the computation of all time-varying variables is July $31^{\text {st }}$, 2013. This date is used because it is unaffected by the reports as the subscribers received the first report in August 2013. The investors who subscribe to the securities account report are on average 45.8 years old, are predominantly male and own an average investment portfolio of 94,000 Euros. In comparison to non-subscribers, subscribers are almost 3 years younger, more likely to be male and own larger portfolios.

All investors in our sample trade quite heavily with an average annual turnover of well above $100 \%$. The turnover of the median investor in the sample is much lower and amounts to 98\%. This indicates that some investors in our sample qualify as heavy traders. In comparison, those who subscribe to the securities account report trade less. The average excess returns as measured by alpha (1-factor and 4-factor) of both subscribers and non-subscribers are negative. However, independent of whether we consider means or medians subscribers have better alphas before we start sending reports. Comparing subscribers and non-subscribers in terms of portfolio diversification, we find that subscribers generally have a more diversified portfolio indicated by a lower Herfindahl-Hirschman-Index ${ }^{4}$ (HHI) (0.24 vs. 0.34) and a lower unsystematic variance share (0.35 vs. 0.46). All previously reported differences between subscribers and non-subscribers are statistically different as t-tests on the mean reveal. This result raises concerns on a potential selection bias which may affect our results. In the section on identification, we discuss how we plan to address this issue.

Our sample of investors seems to be representative of the average German retail investor. In comparison to the average securities account held in Germany (ca. 29.500 Euros in 2013) (Deutsche Bundesbank (Ed.) 2015b, 2015a), the averages in our sample are in the same order of magnitude (ca. 24,400 Euros). The same applies for other characteristics such as turnover, HHI, age and gender (Daniel Dorn and Gur Huberman 2005).

[INSERT TABLE 1 ABOUT HERE]

\footnotetext{
${ }^{4}$ Please see section IV.III Key metrics for a definition of the HHI in this context.
} 
The questionnaire subscribers complete when registering for the securities account report allows for further interesting insights. The information is displayed in Table 2. From the answers, we conclude that the investors are financially literate. The financial literacy questions are based on Maarten van Rooij, Annamaria Lusardi, and Rob Alessie 2011. Moreover, the questionnaire answers show that subscribers do not use their account as "play money accounts": $72 \%$ of subscribers state that this is their main securities account and only $3 \%$ state they had a short-term investment horizon.

\section{[INSERT TABLE 2 ABOUT HERE]}

\section{III.Methodology}

\section{III.I. Difference-in-Differences Analysis}

We conjecture that our reports decrease information costs and make relevant information salient to investors. This enables them to make better investment decisions. In particular, we test whether receiving a securities account report results in an increase in diversification, lower trading (costs), an increase in capital market exposure and ultimately in a better portfolio performance.

The starting point of such an investigation is a simple difference-in-differences approach used in economics and household finance to model the effects of a policy change or a product or service innovation (e.g., Bhattacharya et al. 2012). Such a model is given by (1)

$$
\mathrm{Y}_{\mathrm{i}, \mathrm{t}}-Y_{i, t-1}=\alpha_{\mathrm{i}}+\beta_{1} d_{\text {report }}+\beta_{2} X+\varepsilon_{\mathrm{i}}
$$

Where $Y_{i, t}-Y_{i, t-1}$ represents the change in any key metric for portfolio $i$ measured before and after the securities account reports are sent. $\alpha_{\mathrm{i}}$ displays the constant; $d_{\text {report }}$ is set to one for subscribers and zero otherwise; $X$ is a vector of control variables to account for heterogeneity between households. The effect we are interested in is measured by $\beta_{1}$. The null hypothesis is that the effect of reports on diversification, trading, performance or investment is zero.

Besides exploring the overall effect of report provision on the investment decisions of investors, we also seek to test whether differences in report designs lead to heterogeneity in outcomes. For example, Reports 2-4 show costs and diversification in a more salient way than Report 1. Reports 3 and 4 also show peer group information. Report 4 contains a short and concise executive summary which should make the interpretation of the report even easier. We therefore conjecture that investors should gradually improve more with each report, i.e. the ones 
receiving Report 1 improving least and investors receiving Report 4 improving most. For this test, we exploit the random assignment of the four securities account report designs to investors and test this hypothesis.

The advantage of the DiD setup is that trends that affect both the treatment and the control group are eliminated as long as receiving reports is exogenous. However, we are legally obliged to let investors choose whether to participate in the survey and subscribe to the securities account reports. The data section already indicated that subscribing to reports is not independent of observable investor characteristics, which may lead to self-selection and hence biased results. Thus, running the regression implied by equation (1) using OLS yields the biased effect of the reports on investment behavior.

\section{III.II. Propensity Score Matching}

To deal with the problem of a potential selection bias we implement a propensity score matching initially introduced by Paul R. Rosenbaum and Donald B. Rubin (1983). We estimate the propensity score using a logit specification. ${ }^{5} \mathrm{We}$ choose a rather simple matching estimator as we match for each subscriber one non-subscriber that minimizes the difference in propensity score. The downside of propensity score matching is, however, that many observations are discarded from the analysis. ${ }^{6}$ We match without replacement to avoid a loss in precision. The potential drawback is that we risk being unable to find non-subscribers that best resemble subscribers.

We use investor and portfolio characteristics as well as information on the investors' profession, which is clustered ${ }^{7}$ into five groups to estimate the probability of investors ordering a securities account report. To ensure that the variables are unaffected by receiving securities account reports all independent variables are measured at the end of July 2013 (or over the course of the twelve months prior to July 2013). Beyond including level effects, we also included changes between January 2013 and July 2013.

The logit-regression results displayed in Table 3 reveal that investors that subscribe to

\footnotetext{
${ }^{5}$ In unreported tests, we also try probit specifications. The results do not depend on the specification we choose.

${ }^{6} \mathrm{We}$ also estimated eq. (1) without any matching estimator in place. Results are slightly stronger than without matching. The relevant tables are available upon request.

${ }^{7}$ The groups are split to reflect the differences in education as well as domain specific jobs. Job class 1 refers to finance-related occupations which require university education. Job class 2 refers to finance related jobs which only require apprenticeships. Job class 3 refers to jobs for which attending university is obligatory, but which have no connection to finance. Job class 4 comprises people with jobs unrelated to finance and not requiring university attendance, finally, job class 5 contains other jobs as well as unemployed.
} 
receive securities account reports tend to have a higher $\mathrm{WpHG}^{8}$ risk class. Moreover, they are better diversified (using HHI and unsystematic variance share), they perform better (higher alphas) and trade less (lower turnover). Overall, investors who subscribe seem to be more sophisticated. This finding is in line with previous literature in household finance (cf. Utpal Bhattacharya et al. 2012). We tested the variables for potential multicollinearity issues using an OLS-framework and found no evidence for problems.

\section{[INSERT TABLE 3 ABOUT HERE]}

For matching subscribers and non-subscribers we use model (6) of Table 3. James Heckman and Salvador Navarro-Lozano (2004) show that there is no justification for using goodness-of-fit statistics for selecting variables for matching. Therefore, it is crucial to ensure the validity of the match. We firstly test if there is common support for the subscribers and nonsubscribers. Figure 2 depicts kernel densities for estimated propensity scores and indicates that there is indeed common support.

\section{[INSERT FIGURE 2 ABOUT HERE]}

As the matching is supposed to eliminate differences in observable variables between subscribers and non-subscribers we run t-tests to test for differences between means for subscribers and non-subscribers. Each t-test examines whether the means are different for subscribers and matched non-subscribers. The t-tests are reported in Table 4 and provide no evidence for any remaining differences between the two groups.

\section{[INSERT TABLE 4 ABOUT HERE]}

The assumption that both groups are indeed comparable can be further tested by comparing changes in the portfolio performance, trading behavior, diversification and the investment decisions at any date prior to the introduction of the reports. In our case, we assume the reports would have been introduced any time between January and end of July 2013. Under the null hypothesis that the matching works well we expect no significant differences in behavior between the two groups. Performing such a test is in the spirit of James J. Heckman and V. J. Hotz (1989). For this test, we use the key metrics described in the following section. Table 5 summarizes the results of this test. We find no differences between subscribers and non-subscribers for most variables. In rare occasions (fees and turnover) we find that the effects are in the opposite direction to what we would expect them to be. In unreported tests, we also

\footnotetext{
${ }^{8} \mathrm{WpHG}=$ Wertpapierhandelsgesetz, the German securities investment law which requires a categorization of clients into so-called risk classes.
} 
verify that the results hold if we do not use the changes in variables in the match.

\section{[INSERT TABLE 5 ABOUT HERE]}

Overall, these three tests do not reject the null that the two groups are comparable. Hence, we conclude that our matching works well and use the results to evaluate the effects of the securities account reports on the investment decisions of investors.

Furthermore, the setup of the study allows for testing the robustness of our findings and for further exploring how the securities account reports affect trading decisions of investors.

\section{III.III. Key Metrics}

The securities account reports seek to minimize investors' information costs regarding their portfolio performance. In particular, the aim is to make relevant information salient to investors in order to enable learning from past investment mistakes, e.g. excessive trading and underdiversification. Ultimately, the reports should help clients to make better investment decisions which should also figure in higher risk-adjusted net returns.

To measure the change in trading activity we calculate the portfolio turnover and the fees paid. The computation of the turnovers follows Barber and Odean (2001). In unreported analyses we also use the number of trades. Results are not different from the ones reported in this paper.

The Herfindahl-Hirschmann-Index (HHI) is a commonly used measure of diversification in the literature (Zoran Ivkovic, James Poterba, and Scott J. Weisbenner 2005; Daniel Dorn, Gur Huberman, and Paul Sengmueller 2008; Zoran Ivković, Clemens Sialm, and Scott Weisbenner 2008). It is calculated as the mean of the average absolute squared weights of the single investments in a portfolio on a given day in the observation period over the total portfolio value. Lower values of the measure indicate a higher degree of diversification. Following Daniel Dorn, Gur Huberman, and Paul Sengmueller (2008) we count investment funds as 100 different securities. This is supposed to reflect the idea of naïve diversification and goes beyond the simple count of securities in a portfolio otherwise used (Todd Mitton and Keith Vorkink 2007; Victor DeMiguel, Lorenzo Garlappi, and Raman Uppal 2009). In addition, we compute the idiosyncratic variance share of each portfolio using a 4-factor model (Mark M. Carhart 1997) with the German CDAX Index as the applicable market as well as SMB, HML and MOM factors computed for stocks listed in the CDAX. In this respect, we follow Utpal Bhattacharya et al. (2012). 
As performance measures we use gross and net returns, 1- and 4-factor alphas on net returns as well as the Sharpe-Ratio. For computing the alphas we again apply the factors used for computing the unsystematic variance share.

Finally, we assess percentage change in Euros invested in the portfolio (portfolio value).

\section{IV.Results}

\section{IV.I. Reaction to reports and robustness checks}

We investigate whether the reports affect trading, diversification and performance based on the eighteen months ranging from August 2013 to January 2015.

Results are summarized in Table 6. We first focus on changes in trading activity (column (6) and (7)). Turnover measures trading activity in relation to total portfolio value while fees are an absolute measure of trading activity. We find that the provision of reports reduces the two measures. In unreported tests, we also compute how absolute values of turnover change. We find that turnover is constant for report receivers, whereas it increases for non-subscribers. For fees the value increases for both groups, however, to a smaller extent for subscribers. Hence, the change in fees paid and turnover is just relatively lower for those investors who receive the report. In our regression in Table 6 only the effect on turnover turns out to be statistically significant at the $1 \%$-level.

Focusing on diversification we find that receiving a securities account report seems to help investors in diversifying their portfolio relatively better. For the HHI and the unsystematic variance share we find a negative coefficient for the report dummy. The effect is statistically significant at the $5 \%$ and $1 \%$-level respectively.

Finally, when we assess the change in performance upon receiving reports we find that it affects the performance of investors positively. The annualized 4-factor alpha before transaction costs increases by more than 9 percentage points p.a. $(0.000363 * 252$ trading days $)$ relative to the one of investors in our control group. Expressed in absolute terms (unreported) the performance still increases by 5 percentage points. The effect is statistically significant at the 5\%-level. Using the gross alpha shows that the increase in performance is not driven by savings in transaction costs, but by improved investment decisions of report subscribers. All the above results hold even without the matching.

\section{[INSERT TABLE 6 ABOUT HERE]}

It is possible that outliers bias the results reported in Table 6. In order to mitigate 
potential biases we run a quantile regression on the median as a robustness test. ${ }^{9}$ The results are depicted in Table 7. The effects for trading, diversification and investment remain unaltered. While the coefficients also hold for performance their economic magnitude is smaller. The relative improvement in gross alpha reduces to 2.8 percentage points. However, all results remain statistically significant on at least the $5 \%$-level.

\section{[INSERT TABLE 7 ABOUT HERE]}

The study by Victor Stango and Jonathan Zinman (2014) shows that awareness caused by a survey in some cases leads to better investment decisions. In a further robustness test, we try to test whether awareness drives our results. If it was only awareness, results should not become stronger over time. To test the robustness of our results we check the effects after a period of 12 months. Table 8 summarizes the results. After the reception of 12 reports we find that the effects are in the same direction as presented in Table 6. In contrast to Table 6 the effects are smaller, but still significant, albeit at lower confidence levels. The results allow for two interpretations. First, they underline the robustness of our results after 18 months of report provision, and secondly they show that the effects may increase over time as investors get better at interpreting information in the reports.

\section{[INSERT TABLE 8 ABOUT HERE]}

In Table 9, we focus on those investors who trade within 5 days after having received a report. This is a robustness check and is supposed to capture the effects on investors who most likely read the report. Investors are made aware of the availability of a new report via e-mail and can directly click to read the report. Additionally, they receive a notification once they log in to their account. About $10 \%$ of subscribers to the security account reports do not trade within this time period ever. We conjecture that the remaining $90 \%$ of investors are more likely to have read the reports and assume that trading after the reception of the report is at least partially influenced by the report. Overall, the results remain qualitatively unaltered, however, the effects increase. This result is in line with our expectation.

\section{[INSERT TABLE 9 ABOUT HERE]}

A further robustness test focusses on whether a "need for change" drives investor's reaction to the reports. The reports reveal the fees paid over the last twelve months by investors. We conjecture that those investors with above average fees will benefit more from the report

\footnotetext{
${ }^{9}$ If we use robust regression instead of quantile regressions, the effects remain qualitatively unaltered. Significances on turnover and diversification are unaffected, but the significances for the performance measures weakens and are just above the $10 \%$-level for gross 4 -factor alpha.
} 
as they should notice their overtrading and adapt their behavior. To test if the "need for change" is an important driver we compute median fees paid in the sample and split the sample at this value. We then repeat our analysis for investors with above median fees. The results are depicted in Table 10. Whereas all effects remain qualitatively unaltered we do not find that a larger need for change particularly drives results. The economic magnitude but not the statistical significance increases for the two proxies for trading intensity.

\section{[INSERT TABLE 10 ABOUT HERE]}

The reports do contain a lot of information. Therefore, it may be the case that subscribers suffer from information overload. If the reports were too complicated and too difficult to understand, we would expect that reactions for those investors who are more financially literate are larger and potentially statistically more significant. To test this we use the financial literacy answers from the survey and keep only those investors and their matches in the sample whose literacy is above 3 (i.e., above average). Table 11 shows that results are qualitatively unaltered for more financially literate investors. If information overload was a problem we would have expected effects to be particularly strong for financially literate investors. As this does not seem to be the case, this argument seems less plausible given the overall supportive evidence for the benefit of a securities account report we are presenting here.

\section{[INSERT TABLE 11 ABOUT HERE]}

In the literature on learning Amit Seru, Tyler Shumway, and Noah Stoffman (2010) show that the learning of private investors in investment matters is mainly driven by attrition. Investors who learn about their inferior investment skills stop trading. Against this background, it is important to check whether the results we presented above are also driven by attrition. In our sample, all investors from the group of subscribers as well as from the group of nonsubscribers are equally present and active throughout the entire sample period. However, in the banking industry it is well documented that investors do not close their accounts but rather stop trading and/or reduce their account to small balances (Stephanie Coyles and Timothy C. Gokey 2002; Rex Y. Du, Wagner A. Kamakura, and Carl F. Mela 2007). This effect is usually known as "silent-attrition". In order to check whether silent attrition is driving our results we perform two robustness checks. First, we restrict the sample to those investors whose turnover is equal or above $25 \%$ of the turnover they had before the reception of the first report and the second one is whether the portfolio value was still at least $25 \%$ of the value they had before receiving the first report. Because the results are qualitatively unaltered, we use the first test here. Looking at Table 12 we find that results are unaltered. Thus attrition does not seem to drive our results. 


\section{[INSERT TABLE 12 ABOUT HERE]}

As shown above (III. Data) the accounts of subscribers to the reporting service do not qualify as play-money accounts. Still, we test whether results are different once investors report to have their main account with the broker. The results are summarized in Table 13 and are found to be fully in line with those in Table 6 .

\section{[INSERT TABLE 13 ABOUT HERE]}

Finally, Table 14 shows results for the four different report designs we test. Results from Table 14 show that there is no dominant report design. It seems that it is more important to provide investors with feedback, rather than a specific format in which it is delivered. This suggests that the reports create awareness but are likely not the only source of investors' improved decisions.

\section{[INSERT TABLE 14 ABOUT HERE]}

\section{IV.II. Are the reports also help the average investor?}

We further analyze an important public policy question: do our reports benefit the investors that need feedback most? Or is it only the already sophisticated investors that subscribe and improve? Put differently: Is there evidence that a report could also improve financial decision making for the average investor, who is less financially literate and less active on financial markets.

We found that more (less) active and better (worse) performing investors are more (less) likely to subscribe to the reports (see III. Data). For this test, we use the estimates from the logit regression in Table 3, column 6 to determine the matches and explore who subscribes for the reporting service. We use the estimates from the regression to predict the $25 \%$ of clients (758 investors) with the highest probability of accepting the advice. ${ }^{10} \mathrm{We}$ define those $25 \%$ as "expected to subscribe". Thus, we can test whether investors predicted to subscribe to the reports are the ones who benefit most from the feedback. In fact, we test whether there is a difference in improvement for the 1,137 investors who were not expected to subscribe but subscribed and the 379 investors who were expected to subscribe and really did.

We run the same regression that generated the results in Table 6 for both subgroups. In

\footnotetext{
${ }^{10}$ The methodology follows Bhattacharya et al (2012). However, they use a threshold of five percent. Our conclusions and results remain unaltered using this threshold. Results are also qualitatively unaltered using different cut off points, including $10 \%$, or even $50 \%$.
} 
panel A, we set the dummy to 1 for the 379 subscribers within the group of expected subscribers. For all others the report dummy is set to zero. In panel B, we set the report dummy to 1 for those that subscribed in the subgroup that was not predicted to subscribe. Table 15 reports the results.

\section{[INSERT TABLE 15 ABOUT HERE]}

Panel A summarizes the coefficient estimates of the report dummy for those investors who are expected to subscribe to the reporting service. The coefficients on the "report" variable are qualitatively comparable to the ones in Table 6. Investors improve on investment decisions and coefficients remain significant. These results need to be compared to those of investors who were not expected to subscribe but did in panel B. The coefficients for those investors also indicate that their investment decisions improve. Interestingly, improvements on the Sharpe Ratio, HHI and turnover are even slightly larger for investors who were not predicted to subscribe. In contrast, coefficients on the unsystematic variance share and the Alphas are slightly smaller and less significant. To test for differences between the coefficients in panel A and panel B we apply seemingly unrelated regressions. We only find significant differences for $\mathrm{HHI}$ and unsystematic variance share, albeit only at $10 \%$-level. This result is robust to using a regression specification which uses an interaction term between prediction and the report dummy instead of the sample split.

In another robustness test we focus our attention only to those investors that receive reports and not their matches. As all these investors receive reports we now estimate the regression from Table 6 using a dummy for those investors we expected to subscribe to the reports. The results in Table 16 support the notion that there are hardly any differences between those who were expected to subscribe and those who were not. The only difference being the HHI, which improves ${ }^{11}$ less for those who were expected to subscribe.

\section{[INSERT TABLE 16 ABOUT HERE]}

Since we run this analysis on report subscribers only, we can also control for information we retrieve from our survey. We thus incorporate information on financial literacy, whether investors devote more than an hour per month to investment decisions, whether they trust other people and whether they consider themselves a long-term investor. Additionally, we follow Manju Puri and David T. Robinson 2007 and construct a measure of optimism from the life

\footnotetext{
${ }^{11}$ Recall that a higher HHI shows less diversification and a lower HHI shows more diversification. The HHI is described in IV.III Key Metrics.
} 
expectancy stated by investors. The results from this test are displayed in Table 17.

\section{[INSERT TABLE 17 ABOUT HERE]}

The important result here is that there are hardly any different effects of reports between those who were expected to subscribe and those who were not. In some instances, the coefficient estimates are even larger for investors that were not expected to subscribe. This leads to the conclusion: those less likely to subscribe (and less financially literate) would equally benefit from the reports.

\section{V.Conclusions}

We use a field study to test whether feedback on securities account performance helps investors to learn and improve financial decision-making with respect to their securities account. We conjecture that decreasing information costs for investors and making relevant information salient to them improves outcomes in terms of lower costs and better diversification resulting in higher risk-adjusted returns.

Based on the current literature we develop four different securities account report designs. Over an eighteen-month period we provide more than 1,500 investors with feedback on the development of their securities account, their returns, trading costs and risk-levels as well as their level of diversification. To assess the impact of the reports we apply a DiD analysis in which we compare the trading behavior of report receivers to a control group of investors who did not receive the reports. The control group is defined using a propensity score matching to minimize issues of self-selection and endogeneity. This setup allows us to identify changes in investment behavior resulting from receiving a report.

Our results in this field experiment support the view that providing investors with "postcontractual" feedback on their portfolio helps them improve investment decisions. Overall, we find that our reports help investors improve on trading costs, diversification and performance. The results complement theoretical studies on microeconomic theory like Emir Kamenica, Sendhil Mullainathan, and Richard Thaler (2011). Even if we focus on investors with higher financial sophistication who are more likely to understand the information provided, or investors exhibiting a larger gap between the average fees paid and their own fees, or leave out investors who do not trade within a five-day period after having received a report, we still find that our results hold.

We also find that differences in report designs do not seem to result in different effects in our case. It seems more important that investors receive relevant feedback on their portfolio 
performance rather than receiving it in a specific format. One explanation could be that reports create awareness, but investors then also consider other sources that enable them to make better decisions. Given our results, this seems to benefit investors. This conclusion is also supported by the missing differentiation in effects between Report 1 and Reports 2-4. We would have expected a stronger impact of Reports 2-4 on diversification and cost measures given that Report 1 contains this information in a less salient way than Reports 2-4. However, this expectation is not confirmed in the results. Hence, we have to conclude that the reports increase awareness and may give investors the necessary clues to get relevant advice on what to do somewhere else. Part of our results could also be driven by the awareness created by the survey (Stango and Zinman 2014). However, this would not explain why results become stronger over time. Hence, at least part of the positive results seems to be driven by the reports themselves.

Another explanation for the missing difference in results is that we are looking at average effects. It could be that some investors react to a specific report design in one way and others in the exact opposite way depending on investor characteristics. In future research it might be interesting to explore whether the usefulness of particular report designs varies with investor characteristics. Against the background of the results of John Beshears et al. (2011b) this would seem likely. Although exploring these combinations would in principle be possible with our dataset, it is out of the scope of this study. Another future contribution would be to disentangle the effect and attribute the improvement to the information and their display format and to other information sources.

In order to test to what extent our results may be relevant for less sophisticated investors, we separate our sample into two subgroups of investors according to their likelihood to subscribe to our report. We find that report receivers that are less likely to subscribe and less financially literate show similar improvements in their investment behavior as those who are more likely to subscribe. This leads to the conclusion: those less likely to subscribe (and less financially literate) would equally benefit from the reports. Therefore, if shrouding (in the spirit of Xavier Gabaix and David Laibson 2006) was present in household investing and an implicit wealth transfer from sophisticated to less sophisticated investors (cf. Brad M. Barber et al. 2008 for evidence from Thailand) took place, this study suggests that feedback could be part of a solution. There is no incentive in the market to overcome shrouding and our results suggest that it may not be in the broker's interest to provide feedback to investors as they ultimately start trading less. In any case, the provision of this kind of feedback is costly and difficult to gather and edit, not only for the investor herself but also for any third party. Therefore, it might be worth considering a policy intervention. 


\section{References}

Alba, Joseph W. and J. W. Hutchinson. 1987. "Dimensions of consumer expertise.” Journal of Consumer Research, 13(3): 411-54.

Asbury, Jo-Ellen. 1995. "Overview of focus group research." Qualitative health research, 5(4): 414-20.

Atkins, Paul W. B., Robert E. Wood, and Philip J. Rutgers. 2002. "The effects of feedback format on dynamic decision making." Organizational Behavior and Human Decision Processes, 88(2): 587-604.

Balzer, William K., Michael E. Doherty, and Raymond O'Connor. 1989. "Effects of cognitive feedback on performance.” Psychological Bulletin, 106(3): 410-33.

Balzer, William K., Leslie B. Hammer, Kenneth E. Sumner, Todd R. Birchenough, Sandra P. Martens, and Patrick H. Raymark. 1994. "Effects of cognitive feedback components, display format, and elaboration on performance." Organizational Behavior and Human Decision Processes, 58(3): 369-85.

Barber, Brad M., Chip Heath, and Terrance Odean. 2003. "Good Reasons Sell. ReasonBased Choice Among Group and Individual Investors in the Stock Market." Management Science, 49(12): 1636-52.

Barber, Brad M., Yi-Tsung Lee, Yu-Jane Liu, and Terrance Odean. 2008. “Just How Much Do Individual Investors Lose by Trading?” Review of Financial Studies, 22(2): 609-32.

Barber, Brad M. and Terrance Odean. 2000. "Trading is Hazardous to Your Wealth. The Common Stock Investment Performance of Individual Investors.” The Journal of Finance, 55(2): 773-806.

Barber, Brad M. and Terrance Odean. 2001. "Boys will be Boys. Gender, Overconfidence and Common Stock Investment.” The Quarterly Journal of Economics, 116(1): 261-92.

Barber, Brad M. and Terrance Odean. 2008. "All that glitters. The effect of attention and news on the buying behavior of individual and institutional investors." Review of Financial Studies, 21(2): 785-818.

Barber, Brad M., Terrance Odean, and Lu Zheng. 2005. "Out of Sight, Out of Mind. The Effects of Expenses on Mutual Fund Flows.” Journal of Business, 78(6): 2095-119.

Barberis, Nicholas and Ming Huang. 2001. "Mental accounting, loss aversion, and individual stock returns." The Journal of Finance, 56(4): 1247-92.

Barberis, Nicholas, Ming Huang, and Tano Santos. "Prospect theory and asset prices." The 
Quarterly Journal of Economics.

Barberis, Nicholas, Andrej Shleifer, and Robert W. Vishny. 1998. "A model of investor sentiment." Journal of Financial Economics, 49(3): 307-43.

Benartzi, Shlomo and Richard H. Thaler. 1995. "Myopic loss aversion and the equity premium puzzle." The Quarterly Journal of Economics, 110(1): 73-92.

Beshears, John, James J. Choi, David Laibson, and Brigitte C. Madrian. 2009. "How Does Simplified Disclosure Affect Individuals' Mutual Fund Choices?" National Bureau of Economic Research Working Paper Series, No. 14859.

Beshears, John, James J. Choi, David Laibson, and Brigitte C. Madrian. 2011a. "Does Aggregated Returns Disclosure Increase Portfolio Risk-Taking?" National Bureau of Economic Research Working Paper Series, No. 16868. http://www.nber.org/papers/w16868.

Beshears, John, James J. Choi, David Laibson, Brigitte C. Madrian, and Katherine L. Milkman. 2011b. "The Effect of Providing Peer Information on Retirement Savings Decisions." National Bureau of Economic Research Working Paper Series, No. 17345. http://www.nber.org/papers/w17345.

Bhattacharya, Utpal, Andreas Hackethal, Simon Kaesler, Benjamin Loos, and Steffen Meyer. 2012. "Is unbiased financial advice to retail investors sufficient? Answers from a large field study." Review of Financial Studies, 25(4): 975-1032.

Blume, Marshall and Irwin Friend. 1975. "The Allocation of Wealth to Risky Assets - The Asset Structure of Individual Portfolios and some Implications for Utility Functions." The Journal of Finance, 30(2): 585-603.

Brinson, Gary P., L. R. Hood, and Gilbert L. Beebower. 1986. "Determinants of Portfolio Performance." Financial Analysts Journal, 42(4): 39-44.

Calvet, Laurent E., John Y. Campbell, and Paolo Sodini. 2007. “Down or Out. Assessing the Welfare Costs of Household Investment Mistakes." Journal of Political Economy, 115(5): 707-47.

Campbell, John Y. 2006. "Household Finance.” The Journal of Finance, 61(4): 1553-604.

Campbell, John Y., Howell E. Jackson, Brigitte C. Madrian, and Peter Tufano. 2011. “Consumer Financial Protection.” The Journal of Economic Perspectives, 25(1): 91-114.

Carhart, Mark M. 1997. “On Persistence in Mutual Fund Performance.” The Journal of Finance, 52(1): 57-82.

Chua, Hannah F., J. F. Yates, and Priti Shah. 2006. "Risk avoidance: Graphs versus 
numbers." Memory \& Cognition, 34(2): 399-410.

Coyles, Stephanie and Timothy C. Gokey. 2002. "Customer retention is not enough." The McKinsey Quarterly, 2(2): 81-89.

Cronqvist, Henrik and Stephan Siegel. 2014. "The genetics of investment biases." Journal of Financial Economics, 113(2): 215-34.

Daniel, Kent, David Hirshleifer, and Avanidhar Subrahmanyam. 1998. "Investor Psychology and Security Market under- and Overreactions." The Journal of Finance, 53(6): 1839-85.

Daniel G. Goldstein, Eric J. Johnson, and William F. Sharpe. 2008. "Choosing Outcomes versus Choosing Products: Consumer-Focused Retirement Investment Advice." Journal of Consumer Research, 35(3): 440-56.

DeMiguel, Victor, Lorenzo Garlappi, and Raman Uppal. 2009. "Optimal versus Naive Diversification. How Inefficient is the 1/N Portfolio Strategy?" Review of Financial Studies, 22(5): 1915-53.

Deutsche Bundesbank (Ed.). 2015a. "Statistik über Wertpapierinvestments."(März). http://www.bundesbank.de/Redaktion/DE/Downloads/Statistiken/Geld_Und_Kapitalmaerkt e/Wertpapierbestaende/statistik_ueber_wertpapierinvestments.pdf?_blob=publicationFile.

Deutsche Bundesbank (Ed.). 2015b. "Wertpapierhalterstatistiken zur Analyse des Wertpapierbesitzes in Deutschland und Europa: Methodik und Ergebnisse." Monatsbericht(März): 101-14.

http://www.bundesbank.de/Redaktion/DE/Downloads/Veroeffentlichungen/Monatsberichtsa ufsaetze/2015/2015_03_wertpapierbesitz.pdf?_blob=publicationFile.

Dorn, Daniel and Gur Huberman. 2005. "Talk and Action. What Individual Investors Say and What They Do." Review of Finance, 9(4): 437-81.

Dorn, Daniel, Gur Huberman, and Paul Sengmueller. 2008. "Correlated trading and returns." The Journal of Finance, 63(2): 885-920.

Du, Rex Y., Wagner A. Kamakura, and Carl F. Mela. 2007. "Size and Share of Customer Wallet." Journal of Marketing, 71(2): 94-113.

Duflo, Esther and Emmanuel Saez. 2002. "Participation and investment decisions in a retirement plan. The influence of colleagues' choices." Journal of Public Economics, 85(1): $121-48$.

Fama, Eugene F. and Kenneth R. French. 1993. "Common Risk Factors in the Returns on 
Stocks and Bonds.” Journal of Financial Economics, 33(1): 3-56.

French, Kenneth R. and James Poterba. 1991. "Investor Diversification and International Equity Markets.” American Economic Review, 81(2): 222-26.

Gabaix, Xavier and David Laibson. 2006. "Shrouded Attributes, Consumer Myopia, and Information Suppression in Competitive Markets." The Quarterly Journal of Economics, 121(2): 505-40.

Gerhardt, Ralf and Steffen Meyer. 2013. "The effect of personal portfolio reporting on private investors." Financial Markets and Portfolio Management, 27(3): 257-273.

Glaser, Markus and Martin Weber. 2007. "Why inexperienced investors do not learn. They do not know their past portfolio performance." Finance Research Letters, 4(4): 203-16.

Glenzer, Franca, Helmut Gründl, and Christian Wilde. 2014. "'And Lead Us Not into Temptation': Presentation Formats and the Choice of Risky Alternatives." Available at SSRN.

Gneezy, Uri and Jan Potters. 1997. “An experiment on risk taking and evaluation periods.” The Quarterly Journal of Economics, 112(2): 631-45.

Goetzmann, William N. and Alok Kumar. 2008. "Equity Portfolio Diversification.” Review of Finance, 12(3): 433-63.

Goldstein, Daniel G., Eric J. Johnson, and William Sharpe. 2008. "Choosing Outcomes versus Choosing Products. Consumer-Focused Retirement Investment Advice." Journal of Consumer Research: An Interdisciplinary Quarterly, 35(3): 440-56.

Hackethal, Andreas, Michael Haliassos, and Tullio Jappelli. 2012. "Financial advisors: A case of babysitters?" Journal of Banking \& Finance, 36(2): 509-24.

Harrison, Glenn W. and John A. List. 2004. "Field experiments." Journal of Economic Literature, 42(4): 1009-55.

Heckman, James and Salvador Navarro-Lozano. 2004. "Using matching, instrumental variables, and control functions to estimate economic choice models." The Review of Economics and Statistics, 86(1): 30-57.

Heckman, James J. and V. J. Hotz. 1989. "Choosing among alternative nonexperimental methods for estimating the impact of social programs: The case of manpower training." Journal of the American statistical Association, 84(408): 862-74.

Hoffman, Paul J., Timothy C. Earle, and Paul Slovic. 1981. "Multidimensional functional learning (MFL) and some new conceptions of feedback." Organizational Behavior and Human Performance, 27(1): 75-102. 
Hollands, J. G. and Ian Spence. 1998. "Judging proportion with graphs: The summation model.” Applied Cognitive Psychology, 12(2): 173-90.

Hollands, Justin G. and Ian Spence. 1992. "Judgments of change and proportion in graphical perception." Human Factors: The Journal of the Human Factors and Ergonomics Society, 34(3): $313-34$

Hwang, Mark I. and Jerry W. Lin. 1999. "Information dimension, information overload and decision quality." Journal of Information Science.

Inderst, Roman and Marco Ottaviani. 2009. "Misselling through Agents." American Economic Review, 99(3): 883-908.

Ivkovic, Zoran, James Poterba, and Scott J. Weisbenner. 2005. "Tax-motivated trading by individual investors." American Economic Review, 95(5): 1605-30.

Ivkovic, Zoran and Scott Weisbenner. 2005. "Local Does As Local Is. Information Content of the Geography of Individual Investors' Common Stock Investments." The Journal of Finance, 60(1): 267-306.

Ivković, Zoran, Clemens Sialm, and Scott Weisbenner. 2008. "Portfolio concentration and the performance of individual investors." Journal of Financial \& Quantitative Analysis, 43(3): $613-55$.

Kamenica, Emir, Sendhil Mullainathan, and Richard Thaler. 2011. "Helping consumers know themselves." American Economic Review, 101(3): 417-22.

Kaufmann, Christine, Martin Weber, and Emily Haisley. 2013. "The Role of Experience Sampling and Graphical Displays on One's Investment Risk Appetite." Management Science, 59(2): $323-40$.

Keller, Carmen, Michael Siegrist, and Vivianne Visschers. 2009. "Effect of Risk Ladder Format on Risk Perception in High-and Low-Numerate Individuals." Risk Analysis, 29(9): 1255-64.

Kling, Jeffrey R., Sendhil Mullainathan, Eldar Shafir, Lee Vermeulen, and Marian V. Wrobel. 2008. "Misperception in choosing Medicare drug plans." Unpublished manuscript.

Legge, Gordon E., Yuanchao Gu, and Andrew Luebker. 1989. "Efficiency of graphical perception." Perception \& Psychophysics, 46(4): 365-74.

Lewis, Karen K. 1999. “Trying to Explain Home Bias in Equities and Consumption.” Journal of Economic Literature, 37(2): 571-608.

Lipkus, Isaac M. and J. G. Hollands. 1999. "The visual communication of risk." JNCI 
monographs, 1999(25): 149-63.

Lurie, Nicholas H. and Charlotte H. Mason. 2007. "Visual Representation: Implications for Decision Making." Journal of Marketing, 71(1): 160-77.

Merton, Robert C. 1987. "A simple model of capital market equilibrium with incomplete information." The Journal of Finance, 42: 483-510.

Miller, George A. 1956. "The magical number seven, plus or minus two: some limits on our capacity for processing information.” Psychological Review, 63(2): 81-97.

Mitton, Todd and Keith Vorkink. 2007. "Equilibrium underdiversification and the preference for skewness." Review of Financial Studies, 20(4): 1255-88.

Odean, Terrance. 1998. “Are Investors Reluctant to Realize Their Losses?” The Journal of Finance, 53(5): 1775-98.

Odean, Terrance. 1999. "Do Investors Trade Too Much?” American Economic Review, 89(5): 1278-98.

Puri, Manju and David T. Robinson. 2007. "Optimism and economic choice." Journal of Financial Economics, 86(1): 71-99.

Rosenbaum, Paul R. and Donald B. Rubin. 1983. "The Central Role of the Propensity Score in Observational Studies for Causal Effects." Biometrika, 70(1): 41-55.

Russo, J. E., Richard Staelin, Catherine A. Nolan, Gary J. Russell, and Barbara L. Metcalf. 1986. "Nutrition Information in the Supermarket." Journal of Consumer Research, 13(1): 48-70.

Ryvkin, Dmitry, Marian Krajč, and Andreas Ortmann. 2012. "Are the unskilled doomed to remain unaware?" Journal of Economic Psychology: Research in Economic Psychology and Behavioral Economics, 33(5): 1012-31.

Seru, Amit, Tyler Shumway, and Noah Stoffman. 2010. "Learning by Trading." Review of Financial Studies, 23(2): 705-39.

Sharpe, William F. 1992. "Asset allocation: Management style and performance measurement." The Journal of Portfolio Management, 18(2): 7-19.

Shefrin, Hersh and Meir Statman. 1985. "The Disposition to Sell Winners Too Early and Ride Losers Too Long. Theory and Evidence." The Journal of Finance, 40(3): 777-90.

Sieck, Winston R. and Hal R. Arkes. 2005. "The recalcitrance of overconfidence and its contribution to decision aid neglect." Journal of Behavioral Decision Making, 18(1): 29-53.

Stango, Victor and Jonathan Zinman. 2014. "Limited and varying consumer attention 
evidence from shocks to the salience of bank overdraft fees." Review of Financial Studies: hhu008.

Stiftung Warentest (Ed.), ed. 2013, Was die Bank nicht sagt.

Tan, Joseph K. H. and Izak Benbasat. 1993. "The Effectiveness of Graphical Presentation for Information Extraction: A Cumulative Experimental Approach.” Decision Sciences, 24(1): 167-91.

van Rooij, Maarten, Annamaria Lusardi, and Rob Alessie. 2011. "Financial literacy and stock market participation.” Journal of Financial Economics, 101(2): 449-72.

Vekiri, Ioanna. 2002. "What is the value of graphical displays in learning?" Educational Psychology Review, 14(3): 261-312.

Weber, Joachim, Steffen Meyer, Benjamin Loos, and Andreas Hackethal. 2014. "Which Investment Behaviors Really Matter for Individual Investors?” Available at SSRN.

Weber, Martin and Colin F. Camerer. 1998. "The disposition effect in securities trading. An experimental analysis.” Journal of Economic Behavior \& Organisation, 33: 167-84. 


\section{Figures and Tables}

Figure 1: Number of new subscribers by month

This bar chart shows the number of subscribers over the sample period. The dark grey bar shows the number of portfolios for which reports are computed, whereas the lighter grey bar shows the corresponding number of clients.

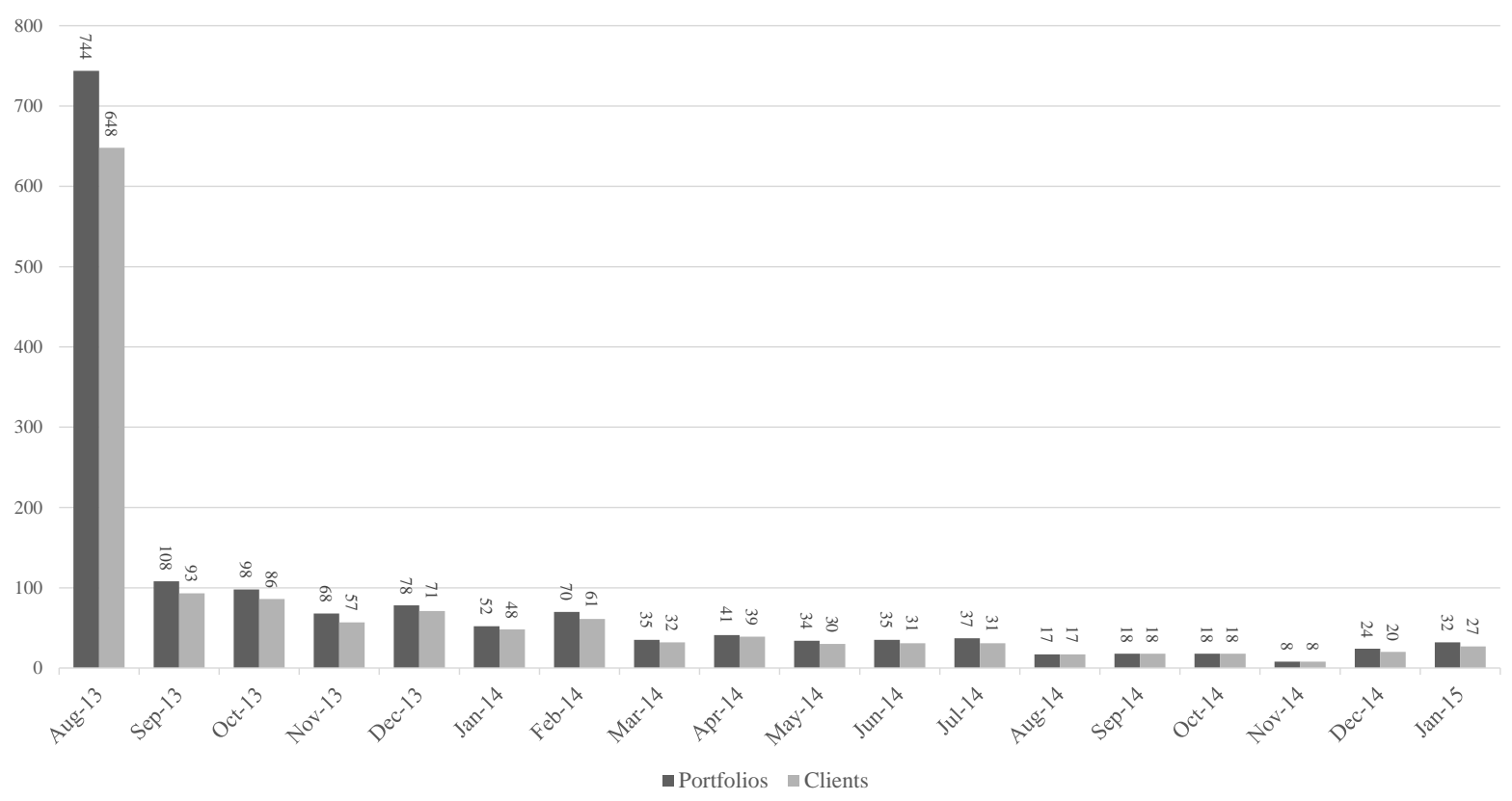

Figure 2: Kernel Densities of Propensity Scores for Subscribers and Nonsubscribers

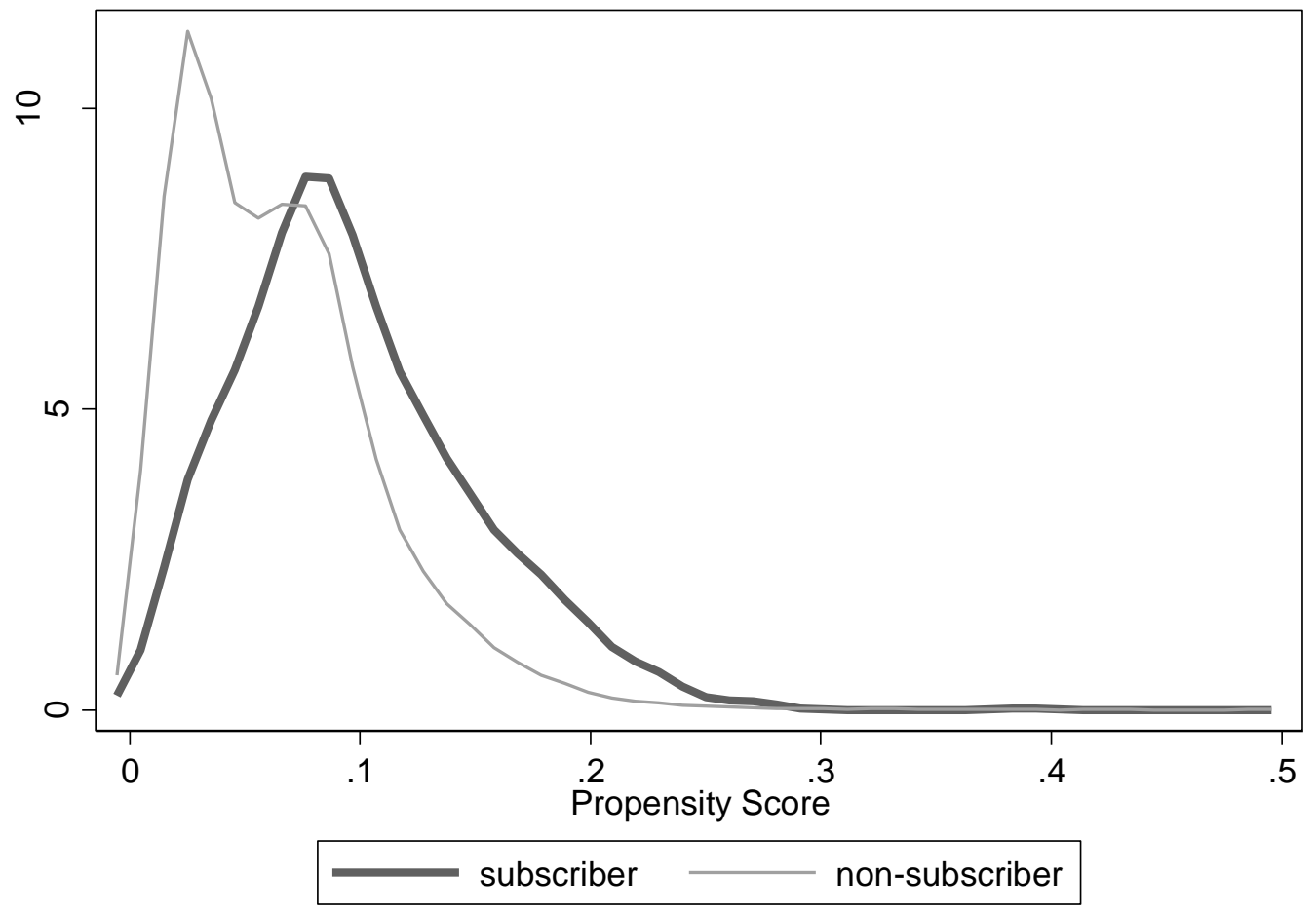




\section{Table 1: Descriptive Statistics}

This table compares subscribers and non-subscribers of the securities account report. The daily turnover is computed based on Brad M. Barber and Terrance Odean 2001. The HHI is computed in line with Dorn, Huberman, and Sengmueller 2008 assuming that a fund is comprised of 100 single stocks and alphas (1-factor and 4-factors) are using the CDAX as the market return and SMB, HML and MOM factors following Eugene F. Fama and Kenneth R. French 1993 and Carhart 1997 respectively. All factors are computed for the Geman market using CDAX companies. The unsystematic variance share is derived from a 4factor model.

\begin{tabular}{|c|c|c|c|c|c|c|c|}
\hline \multirow[b]{2}{*}{ Variables } & \multicolumn{3}{|c|}{ Non subscribers } & \multicolumn{3}{|c|}{ Subscribers } & \multirow{2}{*}{$\frac{\text { T-Test }}{\text { p-value }}$} \\
\hline & Obs. & Mean & Median & Obs. & Mean & Median & \\
\hline \multicolumn{8}{|c|}{ Portfolio Descriptives \& Performance as of July 31, 2013} \\
\hline Portfolio Value & 21,216 & 79,852 & 24,399 & 1,518 & 93,887 & 24,381 & 0.058 \\
\hline Daily Turnover (year before) & 21,216 & 0.0198 & 0.0038 & 1,518 & 0.0103 & 0.0031 & 0.000 \\
\hline Daily No. Trades (year before) & 21,216 & 0.4052 & 0.0913 & 1,518 & 0.2704 & 0.0833 & 0.000 \\
\hline HHI & 21,216 & 0.3462 & 0.2300 & 1,518 & 0.2452 & 0.1418 & 0.000 \\
\hline Fees (year before) & 21,216 & 2.0190 & 0.4683 & 1,518 & 1.4742 & 0.3958 & 0.001 \\
\hline Alpha 1-factor (year before) p.a. & 21,216 & -0.2746 & -0.0449 & 1,518 & -0.0284 & -0.0128 & 0.000 \\
\hline Alpha 4-factor (year before) p.a. & 21,216 & -0.2700 & -0.0430 & 1,518 & -0.0279 & -0.0133 & 0.000 \\
\hline Alpha 1-factor (net) (year before) p.a. & 21,216 & -0.3223 & -0.0569 & 1,518 & -0.0481 & -0.0235 & 0.000 \\
\hline Alpha 4-factor (net) (year before) p.a. & 21,216 & -0.2700 & -0.0430 & 1,518 & -0.0279 & -0.0133 & 0.000 \\
\hline Unsystematic variance share & 21,216 & 0.4656 & 0.5784 & 1,518 & 0.3491 & 0.4294 & 0.000 \\
\hline \multicolumn{8}{|l|}{ Investor Demographics } \\
\hline Age & 21,100 & 50.24 & 50.00 & 1,518 & 45.77 & 43.00 & 0.000 \\
\hline Gender $(1=$ male $)$ & 21,216 & 0.80 & 1.00 & 1,518 & 0.92 & 1.00 & 0.000 \\
\hline WPHG-Risk class & 21,216 & 5.50 & 6.00 & 1,518 & 5.57 & 6.00 & 0.001 \\
\hline
\end{tabular}

\section{Table 2: Descriptive Statistics}

This table summarizes information we collect from a survey among investors who subscribe to the securities account reports. It presents the number of investors, their mean and median values. About 200 investors do not fully complete the survey and hence we cannot calculate their risk-capacity. While for the report production we assume a risk-class of five, we do not show the averages using the imputed values here.

\begin{tabular}{lccc}
\hline & \multicolumn{3}{c}{ Subscribers } \\
\cline { 2 - 4 } Variables & Obs. & Mean & Median \\
\hline Questionnaire results & & & \\
Main Account & 1,518 & 0.72 & 1.00 \\
Financial Literacy (4 = highest) & 1,518 & 3.16 & 3.00 \\
Experience with (3 years and more) & & & \\
$\quad$ Stocks & 1,518 & 0.86 & 1.00 \\
Bonds & 1,518 & 0.46 & 0.00 \\
Funds & 1,518 & 0.59 & 1.00 \\
$\quad$ Options & 1,518 & 0.44 & 0.00 \\
Investment goals & & & \\
$\quad$ Short-term investor & 1,518 & 0.03 & 0.00 \\
$\quad$ Mid-term investor & 1,518 & 0.36 & 0.00 \\
$\quad$ Long-term investor & 1,518 & 0.61 & 1.00 \\
Risk-capacity (Survey Assessment) & 1,390 & 6.92 & 7.00 \\
\hline
\end{tabular}




\section{Table 3: Logit-Regression on subscribing for a Securities Account Report}

This table presents coefficient estimates of logit regressions on a dummy variable set to one if an investor subscribes to the securities account report (the treatment group) and zero otherwise. To ensure that the variables are unaffected by the reports, all independent variables are measured at the end of July 2013, the month before the first securities account report was circulated. Robust z-statistics are reported in parentheses; ***, **, and * denote significance at the $1 \%, 5 \%$, and $10 \%$ levels, respectively.

\begin{tabular}{|c|c|c|c|c|c|c|}
\hline & (1) & (2) & (3) & (4) & (5) & (6) \\
\hline Variables & $\begin{array}{c}\text { Report } \\
\text { Subscriber }\end{array}$ & $\begin{array}{c}\text { Report } \\
\text { Subscriber }\end{array}$ & $\begin{array}{c}\text { Report } \\
\text { Subscriber }\end{array}$ & $\begin{array}{c}\text { Report } \\
\text { Subscriber }\end{array}$ & $\begin{array}{c}\text { Report } \\
\text { Subscriber }\end{array}$ & $\begin{array}{c}\text { Report } \\
\text { Subscriber }\end{array}$ \\
\hline Age & $\begin{array}{r}-0.082716^{* * * *} \\
(0.000)\end{array}$ & $\begin{array}{r}-0.082872 * * * \\
(0.000)\end{array}$ & $\begin{array}{r}-0.080579 * * * \\
(0.000)\end{array}$ & $\begin{array}{r}-0.080102^{* * * *} \\
(0.000)\end{array}$ & $\begin{array}{r}-0.082688^{* * * *} \\
(0.000)\end{array}$ & $\begin{array}{r}-0.093748 * * * \\
(0.000)\end{array}$ \\
\hline $\mathrm{Age}^{\wedge} 2$ & $\begin{array}{r}0.000657^{* * * *} \\
(0.000)\end{array}$ & $\begin{array}{r}0.000631 * * * * \\
(0.000)\end{array}$ & $\begin{array}{r}0.000615^{* * * *} \\
(0.000)\end{array}$ & $\begin{array}{r}0.000608 * * * \\
(0.000)\end{array}$ & $\begin{array}{r}0.000624 * * * \\
(0.000)\end{array}$ & $\begin{array}{r}0.000722 * * * \\
(0.000)\end{array}$ \\
\hline Gender & $\begin{array}{r}1.027057 * * * \\
(0.000)\end{array}$ & $\begin{array}{r}1.071620 * * * \\
(0.000)\end{array}$ & $\begin{array}{r}1.077893^{* * * *} \\
(0.000)\end{array}$ & $\begin{array}{r}1.075877^{* * * *} \\
(0.000)\end{array}$ & $\begin{array}{r}1.088689^{* * * *} \\
(0.000)\end{array}$ & $\begin{array}{r}1.033435^{* * * *} \\
(0.000)\end{array}$ \\
\hline Risk-class (WpHG) & $\begin{array}{r}0.081364 * * \\
(0.023)\end{array}$ & $\begin{array}{r}0.049263 \\
(0.181)\end{array}$ & $\begin{array}{r}0.068825^{*} \\
(0.065)\end{array}$ & $\begin{array}{r}0.095753^{* *} \\
(0.014)\end{array}$ & $\begin{array}{r}0.087627 * * \\
(0.024)\end{array}$ & $\begin{array}{r}0.078766^{* * *} \\
(0.041)\end{array}$ \\
\hline Portfolio value (July 2013) & & $\begin{array}{r}0.000000^{* * * *} \\
(0.009)\end{array}$ & $\begin{array}{r}0.000000^{*} \\
(0.051)\end{array}$ & $\begin{array}{r}0.000000 \\
(0.104)\end{array}$ & $\begin{array}{r}0.000000 \\
(0.209)\end{array}$ & $\begin{array}{r}0.000000 \\
(0.196)\end{array}$ \\
\hline HHI (July 2013) & & $\begin{array}{r}-1.248208 * * * \\
(0.000)\end{array}$ & $\begin{array}{r}-1.512997 * * * * \\
(0.000)\end{array}$ & $\begin{array}{r}-1.412007 * * * \\
(0.000)\end{array}$ & $\begin{array}{r}-1.399954^{* * * *} \\
(0.000)\end{array}$ & $\begin{array}{r}-1.406062^{* * * *} \\
(0.000)\end{array}$ \\
\hline Change of HHI (June 2012 - July 2013) & & & $\begin{array}{r}0.658134^{* * * *} \\
(0.000)\end{array}$ & $\begin{array}{r}0.641049^{* * * *} \\
(0.000)\end{array}$ & $\begin{array}{r}0.631827^{* * * *} \\
(0.000)\end{array}$ & $\begin{array}{r}0.630365^{* * * *} \\
(0.000)\end{array}$ \\
\hline Risky share (July 2013) & & & $\begin{array}{r}1.370422 * * * \\
(0.000)\end{array}$ & $\begin{array}{r}1.111492 * * * \\
(0.000)\end{array}$ & $\begin{array}{r}1.125528 * * * \\
(0.000)\end{array}$ & $\begin{array}{r}1.121559 * * * * \\
(0.000)\end{array}$ \\
\hline Average Turnover (June 2012 - July 2013) & & & $\begin{array}{r}-5.444565^{* * * *} \\
(0.001)\end{array}$ & $\begin{array}{r}-4.194012^{* * * *} \\
(0.006)\end{array}$ & $\begin{array}{r}-3.962250^{* * * *} \\
(0.009)\end{array}$ & $\begin{array}{r}-3.945295^{* * * *} \\
(0.009)\end{array}$ \\
\hline Change of Turnover (June 2012 - July 2013) & & & $\begin{array}{r}2.574516 \\
(0.151)\end{array}$ & $\begin{array}{r}2.231377 \\
(0.213)\end{array}$ & $\begin{array}{r}2.154345 \\
(0.226)\end{array}$ & $\begin{array}{r}2.172056 \\
(0.224)\end{array}$ \\
\hline Alpha (1-factor, June 2012 - July 2013) & & & & $\begin{array}{r}59.762155^{* * * *} \\
(0.000)\end{array}$ & $\begin{array}{r}59.604541^{* * * *} \\
(0.000)\end{array}$ & $\begin{array}{r}59.637605 * * * \\
(0.000)\end{array}$ \\
\hline $\begin{array}{l}\text { Change of 1-factor Alpha (June } 2012 \text { - July } \\
\text { 2013) }\end{array}$ & & & & $\begin{array}{r}-17.433421 \\
(0.112)\end{array}$ & $\begin{array}{r}-16.745174 \\
(0.126)\end{array}$ & $\begin{array}{r}-17.224044 \\
(0.116)\end{array}$ \\
\hline Unystematic variance share (1-factor, June & & & & $-0.284250 * *$ & $-0.277200^{* *}$ & $-0.260844 * *$ \\
\hline 2012 - July 2013) & & & & $(0.016)$ & $(0.019)$ & $(0.027)$ \\
\hline Change of unsystematic variance share (June & & & & $0.367104^{*}$ & $0.394108 * *$ & $0.384470^{*}$ \\
\hline 2012 - July 2013) & & & & $(0.062)$ & $(0.045)$ & $(0.050)$ \\
\hline Number of portfolios & & & & & $\begin{array}{r}0.100981^{* * *} \\
(0.000)\end{array}$ & $\begin{array}{r}0.102594 * * * \\
(0.000)\end{array}$ \\
\hline Job dummy 1 & & & & & & $\begin{array}{r}0.511253^{* * * *} \\
(0.001)\end{array}$ \\
\hline Job dummy 2 & & & & & & $\begin{array}{r}0.522857 * * * \\
(0.003)\end{array}$ \\
\hline Job dummy3 & & & & & & $\begin{array}{r}0.511675^{* * * *} \\
(0.000)\end{array}$ \\
\hline Job dummy4 & & & & & & $\begin{array}{r}0.543667 * * * \\
(0.000)\end{array}$ \\
\hline Constant & $\begin{array}{r}-1.666620^{* * * *} \\
(0.000) \\
\end{array}$ & $\begin{array}{r}-1.109795 * * * \\
(0.000) \\
\end{array}$ & $\begin{array}{r}-2.484856^{* * * *} \\
(0.000) \\
\end{array}$ & $\begin{array}{r}-2.224528 * * * \\
(0.000) \\
\end{array}$ & $\begin{array}{r}-2.275234 * * * \\
(0.000) \\
\end{array}$ & $\begin{array}{r}-2.391767 * * * \\
(0.000) \\
\end{array}$ \\
\hline $\begin{array}{l}\text { Observations } \\
\text { Pseudo R-squared }\end{array}$ & $\begin{array}{l}22,617 \\
0.0285\end{array}$ & $\begin{array}{l}22,617 \\
0.0457\end{array}$ & $\begin{array}{l}22,617 \\
0.0570\end{array}$ & $\begin{array}{l}22,617 \\
0.0601\end{array}$ & $\begin{array}{l}22,617 \\
0.0613\end{array}$ & $\begin{array}{l}22,617 \\
0.0630\end{array}$ \\
\hline
\end{tabular}


Table 4: Individual Characteristics of matched Non-subscribers and Subscribers

This table presents two sample t-tests of mean differences between subscribers and non-subscribers of securities account reports.

\begin{tabular}{|c|c|c|c|c|c|c|c|}
\hline \multirow[b]{2}{*}{ Variables } & \multicolumn{3}{|c|}{ Non subscribers } & \multicolumn{3}{|c|}{ Subscribers } & \multirow{2}{*}{$\frac{\text { T-Test }}{p \text {-value }}$} \\
\hline & Obs. & Mean & Median & Obs. & Mean & Median & \\
\hline \multicolumn{8}{|l|}{ Portfolio Descriptives \& Performance as of July 31, 2013} \\
\hline Age & 1,516 & 45.586 & 45.000 & 1,516 & 45.783 & 43.000 & 0.719 \\
\hline $\operatorname{Age}^{\wedge} 2$ & 1,516 & $2,296.693$ & $2,025.000$ & 1,516 & $2,328.022$ & $1,849.000$ & 0.559 \\
\hline Gender & 1,516 & 0.925 & 1.000 & 1,516 & 0.925 & 1.000 & 1.000 \\
\hline Risk-class (WpHG) & 1,516 & 5.577 & 6.000 & 1,516 & 5.571 & 6.000 & 0.823 \\
\hline Change of HHI (June 2012 - July 2013) & 1,516 & 0.008 & - & 1,516 & 0.004 & 0.000 & 0.580 \\
\hline Risky share (July 2013) & 1,516 & 0.990 & 1.000 & 1,516 & 0.988 & 1.000 & 0.600 \\
\hline Portfolio Value (July 2013) & 1,516 & $97,035.7$ & $28,676.3$ & 1,516 & $93,954.1$ & $24,380.7$ & 0.767 \\
\hline HHI (July 2013) & 1,516 & 0.247 & 0.156 & 1,516 & 0.245 & 0.142 & 0.913 \\
\hline Average Turnover (June 2012 - July 2013) & 1,516 & 0.010 & 0.003 & 1,516 & 0.010 & 0.003 & 0.572 \\
\hline Change of Turnover (June 2012 - July 2013) & 1,516 & 0.001 & 0.000 & 1,516 & 0.002 & 0.000 & 0.057 \\
\hline Alpha (1-factor, June 2012 - July 2013) & 1,516 & 0.000 & 0.000 & 1,516 & 0.000 & 0.000 & 0.954 \\
\hline Change of 1-factor Alpha (June 2012 - July 2013) & 1,516 & 0.000 & 0.000 & 1,516 & 0.000 & 0.000 & 0.627 \\
\hline Unystematic variance share (1-factor, June 2012 - July 2013) & 1,516 & 0.683 & 0.723 & 1,516 & 0.687 & 0.721 & 0.718 \\
\hline Change of unsystematic variance share (June 2012 - July 2013) & 1,516 & 0.070 & 0.054 & 1,516 & 0.071 & 0.057 & 0.839 \\
\hline Number of portfolios & 1,516 & 1.527 & 1.000 & 1,516 & 1.466 & 1.000 & 0.104 \\
\hline
\end{tabular}


Table 5: Placebo-Test for Effectiveness of Matching

This table displays the results for the difference-in-differences analysis using the period before reports were distributed. The columns (1) to (5) measure changes in portfolio performance, columns (6) and (7) changes in diversification, and columns (8) and (9) measure changes in trading behavior. The $p$-values from using clustered standard errors are displayed in parentheses, with $* * *, * *$, and $*$ denoting significance at the $1 \%, 5 \%$, and $10 \%$ levels, respectively.

\begin{tabular}{|c|c|c|c|c|c|c|c|c|c|c|}
\hline \multirow[b]{3}{*}{ Variables } & \multicolumn{5}{|c|}{ Return / Performance } & \multicolumn{2}{|c|}{ Diversification } & \multicolumn{2}{|c|}{ Trading } & \multirow{2}{*}{$\begin{array}{c}\text { Investment } \\
(10)\end{array}$} \\
\hline & $(1)$ & (2) & (3) & (4) & $(5)$ & $(6)$ & (7) & $(8)$ & (9) & \\
\hline & Return & Net- Return & $\begin{array}{c}\text { Alpha (gross) } \\
\text { (1-factor) }\end{array}$ & $\begin{array}{c}\text { Alpha (gross) } \\
\text { (4-factor) }\end{array}$ & Sharpe Ratio & $\begin{array}{c}\text { Unsys. var. } \\
\text { (4-factor) }\end{array}$ & HHI & Fees & Turnover & Size of portfolio \\
\hline Report & $\begin{array}{r}-0.000091 \\
(0.149)\end{array}$ & $\begin{array}{r}-0.000094 \\
(0.150)\end{array}$ & $\begin{array}{r}-0.000045 \\
(0.577)\end{array}$ & $\begin{array}{r}-0.000050 \\
(0.525)\end{array}$ & $\begin{array}{r}-0.009118 \\
(0.407)\end{array}$ & $\begin{array}{r}-0.017700 \\
(0.197)\end{array}$ & $\begin{array}{r}-0.003776 \\
(0.618)\end{array}$ & $\begin{array}{r}0.150952 * * \\
(0.036)\end{array}$ & $\begin{array}{r}0.000994 * \\
(0.068)\end{array}$ & $\begin{array}{r}0.020659 \\
(0.612)\end{array}$ \\
\hline Age & $\begin{array}{r}0.000016 \\
(0.221)\end{array}$ & $\begin{array}{r}0.000017 \\
(0.198)\end{array}$ & $\begin{array}{r}0.000015 \\
(0.353)\end{array}$ & $\begin{array}{r}0.000012 \\
(0.434)\end{array}$ & $\begin{array}{r}0.001121 \\
(0.561)\end{array}$ & $\begin{array}{r}0.006587 * * \\
(0.049)\end{array}$ & $\begin{array}{r}0.002929 * \\
(0.051)\end{array}$ & $\begin{array}{r}-0.003593 \\
(0.783)\end{array}$ & $\begin{array}{r}-0.000049 \\
(0.618)\end{array}$ & $\begin{array}{r}0.000370 \\
(0.962)\end{array}$ \\
\hline $\operatorname{Age}^{\wedge} 2$ & $\begin{array}{r}-0.000000 \\
(0.142)\end{array}$ & $\begin{array}{r}-0.000000 \\
(0.129)\end{array}$ & $\begin{array}{r}-0.000000 \\
(0.329)\end{array}$ & $\begin{array}{r}-0.000000 \\
(0.379)\end{array}$ & $\begin{array}{r}-0.000009 \\
(0.680)\end{array}$ & $\begin{array}{r}-0.000057^{*} \\
(0.087)\end{array}$ & $\begin{array}{r}-0.000027^{*} \\
(0.072)\end{array}$ & $\begin{array}{r}0.000087 \\
(0.535)\end{array}$ & $\begin{array}{r}0.000001 \\
(0.396)\end{array}$ & $\begin{array}{r}0.000004 \\
(0.965)\end{array}$ \\
\hline Gender & $\begin{array}{r}-0.000035 \\
(0.637)\end{array}$ & $\begin{array}{r}-0.000045 \\
(0.557)\end{array}$ & $\begin{array}{r}0.000075 \\
\quad(0.375)\end{array}$ & $\begin{array}{r}0.000075 \\
(0.348)\end{array}$ & $\begin{array}{r}0.011937 \\
(0.233)\end{array}$ & $\begin{array}{r}0.009774 \\
(0.695)\end{array}$ & $\begin{array}{r}-0.002894 \\
(0.842)\end{array}$ & $\begin{array}{r}0.109579 \\
(0.217)\end{array}$ & $\begin{array}{r}-0.000334 \\
(0.772)\end{array}$ & $\begin{array}{r}0.012944 \\
(0.858)\end{array}$ \\
\hline Risk-class (WpHG) & $\begin{array}{r}0.000029 \\
(0.351)\end{array}$ & $\begin{array}{r}0.000028 \\
(0.375)\end{array}$ & $\begin{array}{r}0.000116^{* * * *} \\
(0.004)\end{array}$ & $\begin{array}{r}0.000111^{* * *} \\
(0.004)\end{array}$ & $\begin{array}{r}0.015098^{* * * *} \\
(0.005)\end{array}$ & $\begin{array}{r}0.002688 \\
(0.784)\end{array}$ & $\begin{array}{r}-0.008834 \\
(0.152)\end{array}$ & $\begin{array}{r}-0.044741 \\
(0.497)\end{array}$ & $\begin{array}{r}-0.000695 \\
(0.221)\end{array}$ & $\begin{array}{r}0.065958 * * \\
(0.019)\end{array}$ \\
\hline Number of portfolios & $\begin{array}{r}-0.000050^{* *} * \\
(0.038)\end{array}$ & $\begin{array}{r}-0.000047^{*} \\
(0.054)\end{array}$ & $\begin{array}{r}-0.000093 * * * \\
(0.002)\end{array}$ & $\begin{array}{r}-0.000090 * * * \\
(0.002)\end{array}$ & $\begin{array}{r}-0.012288 * * * \\
(0.002)\end{array}$ & $\begin{array}{r}-0.001304 \\
(0.860)\end{array}$ & $\begin{array}{r}-0.000914 \\
(0.749)\end{array}$ & $\begin{array}{r}0.014298 \\
(0.629)\end{array}$ & $\begin{array}{r}-0.000247 \\
(0.235)\end{array}$ & $\begin{array}{r}-0.000986 \\
(0.960)\end{array}$ \\
\hline Portfolio size (July 2013) & $\begin{array}{r}-0.000000 \\
(0.986)\end{array}$ & $\begin{array}{r}0.000000 \\
(0.883)\end{array}$ & $\begin{array}{r}-0.000000 * \\
(0.067)\end{array}$ & $\begin{array}{r}-0.000000 * \\
(0.058)\end{array}$ & $\begin{array}{r}-0.000000 \\
(0.264)\end{array}$ & $\begin{array}{r}-0.000000 \\
(0.940)\end{array}$ & $\begin{array}{r}-0.000000^{* * * *} \\
(0.001)\end{array}$ & $\begin{array}{r}0.000001^{*} \\
(0.067)\end{array}$ & $\begin{array}{r}-0.000000^{* * * *} \\
(0.010)\end{array}$ & $\begin{array}{r}0.000000 * * * \\
(0.000)\end{array}$ \\
\hline Job dummy1 & $\begin{array}{r}-0.000120 \\
(0.272)\end{array}$ & $\begin{array}{r}-0.000131 \\
(0.238)\end{array}$ & $\begin{array}{r}-0.000101 \\
(0.425)\end{array}$ & $\begin{array}{r}-0.000090 \\
(0.459)\end{array}$ & $\begin{array}{r}-0.019152 \\
(0.214)\end{array}$ & $\begin{array}{r}-0.012463 \\
(0.718)\end{array}$ & $\begin{array}{r}-0.027852 \\
(0.119)\end{array}$ & $\begin{array}{r}0.123977 \\
(0.366)\end{array}$ & $\begin{array}{r}0.000990 \\
(0.441)\end{array}$ & $\begin{array}{r}-0.002251 \\
(0.980)\end{array}$ \\
\hline Job dummy2 & $\begin{array}{r}-0.000187 \\
(0.294)\end{array}$ & $\begin{array}{r}-0.000181 \\
(0.308)\end{array}$ & $\begin{array}{r}-0.000161 \\
(0.380)\end{array}$ & $\begin{array}{r}-0.000189 \\
(0.331)\end{array}$ & $\begin{array}{r}-0.019092 \\
(0.380)\end{array}$ & $\begin{array}{r}-0.054621 \\
(0.165)\end{array}$ & $\begin{array}{r}-0.025126 \\
(0.214)\end{array}$ & $\begin{array}{r}0.043031 \\
(0.730)\end{array}$ & $\begin{array}{r}0.002275 \\
(0.156)\end{array}$ & $\begin{array}{r}-0.160195^{*} \\
(0.094)\end{array}$ \\
\hline Job dummy3 & $\begin{array}{r}-0.000015 \\
(0.863)\end{array}$ & $\begin{array}{r}-0.000025 \\
(0.774)\end{array}$ & $\begin{array}{r}0.000010 \\
(0.918)\end{array}$ & $\begin{array}{r}0.000023 \\
(0.820)\end{array}$ & $\begin{array}{r}0.005359 \\
(0.646)\end{array}$ & $\begin{array}{r}-0.015339 \\
(0.629)\end{array}$ & $\begin{array}{r}-0.017058 \\
(0.280)\end{array}$ & $\begin{array}{r}0.097737 \\
(0.358)\end{array}$ & $\begin{array}{r}0.000943 \\
(0.380)\end{array}$ & $\begin{array}{r}0.003866 \\
(0.961)\end{array}$ \\
\hline Job dummy4 & $\begin{array}{r}0.000059 \\
(0.587)\end{array}$ & $\begin{array}{r}0.000043 \\
(0.705)\end{array}$ & $\begin{array}{r}0.000251^{*} \\
(0.058)\end{array}$ & $\begin{array}{r}0.000230^{*} \\
(0.073)\end{array}$ & $\begin{array}{r}0.037042 * * \\
(0.032)\end{array}$ & $\begin{array}{r}-0.005423 \\
(0.870)\end{array}$ & $\begin{array}{r}-0.025138 \\
(0.132)\end{array}$ & $\begin{array}{r}0.276041^{* *} \\
(0.025)\end{array}$ & $\begin{array}{r}0.001351 \\
(0.267)\end{array}$ & $\begin{array}{r}-0.014401 \\
(0.866)\end{array}$ \\
\hline Constant & $\begin{array}{r}0.000019 \\
(0.945) \\
\end{array}$ & $\begin{array}{r}0.000006 \\
(0.982) \\
\end{array}$ & $\begin{array}{r}-0.000631 * \\
(0.088) \\
\end{array}$ & $\begin{array}{r}-0.000530 \\
(0.135)\end{array}$ & $\begin{array}{r}-0.075626^{*} \\
(0.086) \\
\end{array}$ & $\begin{array}{r}-0.248625^{* *} \\
(0.018)\end{array}$ & $\begin{array}{r}0.012788 \\
(0.782) \\
\end{array}$ & $\begin{array}{r}0.106342 \\
(0.837) \\
\end{array}$ & $\begin{array}{r}0.004957 \\
(0.229) \\
\end{array}$ & $\begin{array}{r}0.074326 \\
(0.753) \\
\end{array}$ \\
\hline Observations & 3,032 & 3,032 & 3,032 & 3,032 & 3,032 & 3,032 & 3,032 & 3,032 & 3,032 & 3,032 \\
\hline R-squared & 0.006 & 0.005 & 0.007 & 0.007 & 0.007 & 0.005 & 0.004 & 0.012 & 0.006 & 0.014 \\
\hline
\end{tabular}


Table 6: Effect of Securities Account Reports (18 months after first distribution)

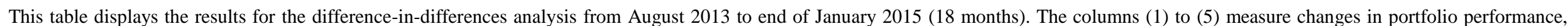
columns (6) and (7) changes in diversification, and columns (8) and (9) measure changes in trading behavior. The $p$-values from using clustered standard errors are displayed in parentheses, with ***, $* *$, and $*$ denoting significance at the $1 \%, 5 \%$, and $10 \%$ levels, respectively.

\begin{tabular}{|c|c|c|c|c|c|c|c|c|c|c|}
\hline \multirow[b]{3}{*}{ Variables } & \multicolumn{5}{|c|}{ Return / Performance } & \multicolumn{2}{|c|}{ Diversification } & \multicolumn{2}{|c|}{ Trading } & \multirow{2}{*}{$\begin{array}{c}\text { Investment } \\
(10)\end{array}$} \\
\hline & (1) & (2) & (3) & (4) & (5) & (6) & (7) & $(8)$ & (9) & \\
\hline & Return & Net- Return & $\begin{array}{c}\text { Alpha (gross) } \\
\text { (1-factor) }\end{array}$ & $\begin{array}{c}\text { Alpha (gross) } \\
\text { (4-factor) }\end{array}$ & Sharpe Ratio & $\begin{array}{l}\text { Unsys. var. } \\
\text { (4-factor) }\end{array}$ & HHI & Fees & Turnover & Size of portfolio \\
\hline \multirow[t]{2}{*}{ Report } & $0.000431 * * *$ & $0.000455^{* * *}$ & $0.000344 * *$ & $0.000363^{* *}$ & $0.065338 * *$ & $-0.020915^{* * *}$ & $-0.020756^{* * *}$ & -0.095084 & $-0.002700 * * *$ & 0.053097 \\
\hline & $(0.009)$ & $(0.007)$ & $(0.023)$ & $(0.016)$ & $(0.018)$ & $(0.004)$ & $(0.020)$ & $(0.480)$ & $(0.001)$ & $(0.337)$ \\
\hline \multirow[t]{2}{*}{ Age } & -0.000019 & -0.000020 & -0.000022 & -0.000019 & -0.003764 & -0.001683 & -0.000325 & -0.000373 & -0.000012 & $0.022048 * *$ \\
\hline & $(0.415)$ & $(0.399)$ & $(0.365)$ & $(0.437)$ & $(0.417)$ & $(0.230)$ & $(0.844)$ & $(0.989)$ & $(0.936)$ & $(0.045)$ \\
\hline \multirow[t]{2}{*}{$\mathrm{Age}^{\wedge} 2$} & 0.000000 & 0.000000 & 0.000000 & 0.000000 & 0.000036 & 0.000008 & -0.000007 & -0.000026 & -0.000000 & $-0.000222^{*}$ \\
\hline & $(0.259)$ & $(0.252)$ & $(0.299)$ & $(0.357)$ & $(0.396)$ & $(0.558)$ & $(0.652)$ & (0.916) & $(0.855)$ & $(0.051)$ \\
\hline \multirow[t]{2}{*}{ Gender } & -0.000032 & -0.000015 & -0.000041 & -0.000054 & -0.013254 & $-0.023934 *$ & -0.011221 & -0.566227 & -0.000818 & -0.028081 \\
\hline & $(0.785)$ & $(0.900)$ & $(0.729)$ & $(0.636)$ & $(0.443)$ & $(0.053)$ & $(0.500)$ & $(0.262)$ & $(0.780)$ & $(0.764)$ \\
\hline \multirow[t]{2}{*}{ Risk-class (WpHG) } & $-0.000186^{* * *}$ & $-0.000192 * * *$ & $-0.000251^{* * *}$ & $-0.000220^{* * *}$ & $-0.035716^{* * *}$ & $0.009055^{*}$ & -0.000335 & 0.056796 & -0.000029 & 0.040844 \\
\hline & $(0.003)$ & $(0.002)$ & $(0.000)$ & $(0.001)$ & $(0.003)$ & $(0.063)$ & $(0.957)$ & $(0.456)$ & $(0.959)$ & $(0.227)$ \\
\hline \multirow[t]{2}{*}{ Number of portfolios } & $0.000133^{* *}$ & $0.000137 * *$ & $0.000127 * *$ & $0.000123^{* *}$ & $0.026421 * * *$ & 0.000830 & -0.001793 & -0.091696 & -0.000326 & 0.006815 \\
\hline & $(0.013)$ & $(0.012)$ & $(0.010)$ & $(0.012)$ & $(0.003)$ & $(0.830)$ & $(0.647)$ & $(0.130)$ & $(0.367)$ & $(0.789)$ \\
\hline \multirow[t]{2}{*}{ Portfolio size (July 2013) } & 0.000000 & 0.000000 & 0.000000 & 0.000000 & 0.000000 & $0.000000^{* * *}$ & $0.000000^{* *}$ & 0.000000 & 0.000000 & 0.000000 \\
\hline & $(0.375)$ & $(0.373)$ & $(0.432)$ & $(0.586)$ & $(0.218)$ & $(0.001)$ & $(0.048)$ & $(0.535)$ & $(0.752)$ & $(0.792)$ \\
\hline \multirow[t]{2}{*}{ Job dummy1 } & -0.000278 & -0.000275 & -0.000101 & -0.000217 & -0.015677 & 0.008231 & 0.028718 & -0.203614 & -0.002585 & 0.093390 \\
\hline & $(0.469)$ & $(0.485)$ & $(0.703)$ & $(0.399)$ & $(0.641)$ & $(0.595)$ & (0.195) & $(0.478)$ & $(0.301)$ & $(0.490)$ \\
\hline \multirow[t]{2}{*}{ Job dummy 2} & -0.000007 & -0.000015 & -0.000037 & -0.000123 & -0.000124 & 0.025818 & 0.016712 & 0.828863 & -0.000601 & -0.154708 \\
\hline & (0.976) & $(0.947)$ & (0.866) & $(0.535)$ & $(0.997)$ & $(0.166)$ & $(0.510)$ & (0.166) & (0.876) & $(0.307)$ \\
\hline \multirow[t]{2}{*}{ Job dummy3 } & 0.000040 & 0.000045 & 0.000061 & -0.000028 & 0.005930 & 0.014796 & 0.017566 & -0.298475 & $-0.004093 *$ & -0.001217 \\
\hline & (0.832) & $(0.816)$ & $(0.740)$ & $(0.862)$ & (0.809) & $(0.287)$ & $(0.390)$ & $(0.280)$ & $(0.093)$ & (0.992) \\
\hline \multirow[t]{2}{*}{ Job dummy 4} & -0.000373 & -0.000373 & -0.000415 & $-0.000459^{*}$ & $-0.090885^{*}$ & 0.013802 & 0.020190 & -0.225500 & -0.002998 & -0.031425 \\
\hline & (0.133) & $(0.141)$ & $(0.137)$ & $(0.075)$ & $(0.071)$ & $(0.364)$ & $(0.346)$ & $(0.400)$ & $(0.227)$ & $(0.815)$ \\
\hline \multirow[t]{2}{*}{ Constant } & 0.000586 & 0.000606 & $0.001582 * *$ & $0.001506^{* *}$ & 0.172341 & -0.021363 & 0.047537 & 0.854356 & $0.008054 *$ & -0.273787 \\
\hline & $(0.327)$ & $(0.321)$ & $(0.020)$ & $(0.024)$ & $(0.199)$ & $(0.605)$ & $(0.320)$ & $(0.245)$ & $(0.062)$ & $(0.361)$ \\
\hline Observations & 3,032 & 3,032 & 3,032 & 3,032 & 3,032 & 3,032 & 3,032 & 3,032 & 3,032 & 3,032 \\
\hline R-squared & 0.006 & 0.007 & 0.007 & 0.006 & 0.007 & 0.011 & 0.007 & 0.010 & 0.008 & 0.004 \\
\hline
\end{tabular}




\section{Table 7: Effect of Securities Account Reports (18 months after first distribution, quantile regression on median)}

This table displays the results for the difference-in-differences analysis from August 2013 to end of January 2015 (18 months). The columns (1) to (5) measure changes in portfolio performance, columns (6) and (7) changes in diversification, and columns (8) and (9) measure changes in trading behavior. The $p$-values from using clustered standard errors are displayed in parentheses, with ***, $* *$, and $*$ denoting significance at the $1 \%, 5 \%$, and $10 \%$ levels, respectively.

\begin{tabular}{|c|c|c|c|c|c|c|c|c|c|c|}
\hline \multirow[b]{3}{*}{ Variables } & \multicolumn{5}{|c|}{ Return / Performance } & \multicolumn{2}{|c|}{ Diversification } & \multicolumn{2}{|c|}{ Trading } & \multirow{2}{*}{$\begin{array}{c}\text { Investment } \\
(10)\end{array}$} \\
\hline & (1) & (2) & (3) & (4) & (5) & (6) & (7) & $(8)$ & (9) & \\
\hline & Return & Net- Return & $\begin{array}{c}\text { Alpha (gross) } \\
\text { (1-factor) }\end{array}$ & $\begin{array}{c}\text { Alpha (gross) } \\
\text { (4-factor) }\end{array}$ & Sharpe Ratio & $\begin{array}{l}\text { Unsys. var. } \\
\text { (4-factor) }\end{array}$ & HHI & Fees & Turnover & Size of portfolio \\
\hline \multirow[t]{2}{*}{ Report } & $0.000118^{* * *}$ & $0.000120^{* * *}$ & $0.000071^{* *}$ & $0.000113 * * *$ & $0.013119 * *$ & $-0.012913^{* *}$ & $-0.001301 * * *$ & $-0.023880 * *$ & $-0.000169 * * *$ & $0.059184^{*}$ \\
\hline & $(0.002)$ & $(0.006)$ & $(0.027)$ & $(0.001)$ & $(0.018)$ & $(0.022)$ & $(0.008)$ & $(0.045)$ & $(0.010)$ & $(0.088)$ \\
\hline \multirow[t]{2}{*}{ Age } & 0.000001 & 0.000002 & -0.000004 & -0.000005 & 0.000182 & -0.001756 & 0.000014 & -0.000418 & -0.000011 & -0.002902 \\
\hline & $(0.913)$ & $(0.822)$ & $(0.547)$ & $(0.471)$ & $(0.866)$ & $(0.110)$ & $(0.881)$ & $(0.857)$ & $(0.368)$ & $(0.665)$ \\
\hline \multirow[t]{2}{*}{$\mathrm{Age}^{\wedge} 2$} & -0.000000 & -0.000000 & 0.000000 & 0.000000 & -0.000003 & 0.000009 & -0.000001 & 0.000019 & 0.000000 & 0.000028 \\
\hline & $(0.847)$ & $(0.789)$ & $(0.594)$ & $(0.535)$ & $(0.789)$ & $(0.418)$ & $(0.447)$ & $(0.428)$ & $(0.131)$ & $(0.679)$ \\
\hline \multirow[t]{2}{*}{ Gender } & -0.000016 & -0.000006 & -0.000008 & -0.000018 & 0.004109 & $-0.017878^{*}$ & $0.002349 * *$ & 0.004224 & -0.000038 & 0.041252 \\
\hline & $(0.829)$ & $(0.946)$ & $(0.900)$ & $(0.779)$ & $(0.701)$ & $(0.100)$ & $(0.013)$ & $(0.854)$ & $(0.762)$ & $(0.539)$ \\
\hline \multirow[t]{2}{*}{ Risk-class (WpHG) } & 0.000002 & 0.000005 & -0.000025 & -0.000012 & 0.001225 & $0.011122 * * *$ & -0.000352 & 0.008527 & 0.000002 & 0.038696 \\
\hline & $(0.939)$ & $(0.871)$ & $(0.262)$ & $(0.612)$ & $(0.749)$ & $(0.004)$ & $(0.297)$ & $(0.302)$ & $(0.960)$ & $(0.108)$ \\
\hline \multirow[t]{2}{*}{ Number of portfolios } & 0.000008 & 0.000008 & -0.000004 & -0.000007 & 0.002809 & 0.001495 & 0.000016 & $-0.015708 * * *$ & -0.000019 & -0.020638 \\
\hline & $(0.658)$ & $(0.722)$ & $(0.822)$ & $(0.681)$ & $(0.303)$ & $(0.591)$ & $(0.946)$ & $(0.008)$ & $(0.562)$ & $(0.232)$ \\
\hline \multirow[t]{2}{*}{ Portfolio size (July 2013) } & -0.000000 & -0.000000 & -0.000000 & -0.000000 & -0.000000 & $0.000000^{* *}$ & 0.000000 & $-0.000000 * * *$ & $-0.000000 * * *$ & 0.000000 \\
\hline & $(0.473)$ & $(0.492)$ & $(0.434)$ & $(0.194)$ & $(0.879)$ & $(0.013)$ & $(0.305)$ & $(0.000)$ & $(0.002)$ & $(0.519)$ \\
\hline \multirow[t]{2}{*}{ Job dummy1 } & -0.000050 & -0.000045 & -0.000001 & -0.000048 & -0.006160 & -0.005016 & $0.001993 *$ & 0.001649 & -0.000004 & 0.004906 \\
\hline & $(0.593)$ & $(0.664)$ & $(0.988)$ & $(0.557)$ & $(0.646)$ & $(0.713)$ & $(0.091)$ & $(0.954)$ & $(0.980)$ & $(0.953)$ \\
\hline \multirow[t]{2}{*}{ Job dummy2 } & $-0.000238^{* *}$ & $-0.000248^{* *}$ & -0.000147 & $-0.000173^{*}$ & -0.020586 & -0.007300 & $0.003646^{* * *}$ & 0.025550 & $0.000326^{*}$ & -0.092393 \\
\hline & $(0.028)$ & $(0.041)$ & $(0.102)$ & $(0.071)$ & $(0.185)$ & $(0.645)$ & $(0.008)$ & $(0.446)$ & $(0.076)$ & $(0.344)$ \\
\hline \multirow[t]{2}{*}{ Job dummy3 } & -0.000104 & -0.000117 & -0.000039 & -0.000067 & -0.010791 & -0.003935 & 0.001363 & -0.006118 & -0.000174 & -0.001818 \\
\hline & $(0.222)$ & $(0.219)$ & $(0.578)$ & $(0.373)$ & $(0.377)$ & $(0.752)$ & $(0.205)$ & $(0.816)$ & $(0.228)$ & $(0.981)$ \\
\hline \multirow[t]{2}{*}{ Job dummy4 } & $-0.000193^{* *}$ & $-0.000212 * *$ & -0.000120 & -0.000130 & $-0.023090^{*}$ & -0.008296 & 0.001110 & -0.027772 & -0.000229 & -0.023138 \\
\hline & $(0.031)$ & $(0.035)$ & $(0.106)$ & $(0.101)$ & $(0.072)$ & $(0.526)$ & $(0.326)$ & $(0.315)$ & $(0.131)$ & $(0.774)$ \\
\hline \multirow[t]{2}{*}{ Constant } & -0.000141 & -0.000185 & $0.000466^{* *}$ & $0.000509 * *$ & -0.040698 & -0.010413 & -0.000562 & 0.005917 & 0.000380 & 0.126690 \\
\hline & $(0.536)$ & $(0.469)$ & $(0.014)$ & $(0.012)$ & $(0.213)$ & $(0.755)$ & $(0.845)$ & $(0.933)$ & $(0.327)$ & $(0.533)$ \\
\hline Observations & 3,032 & 3,032 & 3,032 & 3,032 & 3,032 & 3,032 & 3,032 & 3,032 & 3,032 & 3,032 \\
\hline R-squared & 0.006 & 0.007 & 0.007 & 0.006 & 0.007 & 0.011 & 0.007 & 0.010 & 0.008 & 0.004 \\
\hline
\end{tabular}


Table 8: Effect of Securities Account Reports (12 months after first distribution)

This table displays the results for the difference-in-differences analysis from August 2013 to end of July 2014 (12 months). The columns (1) to (5) measure changes in portfolio performance, columns (6) and (7) changes in diversification, and columns (8) and (9) measure changes in trading behavior. The $p$-values from using clustered standard errors are displayed in parentheses, with $* * *, * *$, and $*$ denoting significance at the $1 \%, 5 \%$, and $10 \%$ levels, respectively.

\begin{tabular}{|c|c|c|c|c|c|c|c|c|c|c|}
\hline \multirow[b]{3}{*}{ Variables } & \multicolumn{5}{|c|}{ Return / Performance } & \multicolumn{2}{|c|}{ Diversification } & \multicolumn{2}{|c|}{ Trading } & \multirow{2}{*}{$\begin{array}{c}\text { Investment } \\
(10)\end{array}$} \\
\hline & (1) & (2) & (3) & (4) & $(5)$ & (6) & (7) & $(8)$ & (9) & \\
\hline & Return & Net- Return & $\begin{array}{c}\text { Alpha (gross) } \\
\text { (1-factor) }\end{array}$ & $\begin{array}{c}\text { Alpha (gross) } \\
\text { (4-factor) }\end{array}$ & Sharpe Ratio & $\begin{array}{l}\text { Unsys. var. } \\
\text { (4-factor) }\end{array}$ & HHI & Fees & Turnover & Size of portfolio \\
\hline \multirow[t]{2}{*}{ Report } & 0.000238 & 0.000255 & 0.000165 & $0.000184 *$ & $0.035064 * *$ & $-0.025891 * * *$ & -0.005594 & -0.003289 & $-0.001435^{*}$ & 0.045943 \\
\hline & $(0.116)$ & $(0.101)$ & $(0.115)$ & $(0.093)$ & $(0.040)$ & $(0.000)$ & $(0.498)$ & $(0.978)$ & $(0.075)$ & $(0.317)$ \\
\hline \multirow[t]{2}{*}{ Age } & -0.000017 & -0.000018 & -0.000013 & -0.000016 & -0.001598 & $-0.002547 * *$ & 0.000170 & 0.003731 & 0.000074 & 0.023409 \\
\hline & $(0.372)$ & $(0.359)$ & $(0.432)$ & $(0.320)$ & $(0.535)$ & $(0.039)$ & $(0.916)$ & $(0.872)$ & $(0.589)$ & $(0.260)$ \\
\hline \multirow[t]{2}{*}{$\operatorname{Age}^{\wedge} 2$} & 0.000000 & 0.000000 & 0.000000 & 0.000000 & 0.000012 & 0.000020 & -0.000003 & -0.000038 & -0.000001 & -0.000229 \\
\hline & $(0.310)$ & $(0.303)$ & $(0.469)$ & $(0.327)$ & $(0.641)$ & $(0.112)$ & $(0.835)$ & $(0.864)$ & $(0.497)$ & $(0.253)$ \\
\hline \multirow[t]{2}{*}{ Gender } & 0.000043 & 0.000059 & 0.000011 & 0.000012 & -0.002580 & $-0.023335^{* *}$ & 0.004484 & -0.721662 & -0.001125 & 0.107420 \\
\hline & $(0.658)$ & $(0.551)$ & $(0.911)$ & $(0.907)$ & $(0.850)$ & $(0.039)$ & $(0.761)$ & $(0.148)$ & $(0.687)$ & $(0.402)$ \\
\hline \multirow[t]{2}{*}{ Risk-class (WpHG) } & -0.000062 & -0.000063 & $-0.000127 * *$ & $-0.000138 * * *$ & $-0.016337 * *$ & -0.002299 & 0.005716 & 0.004465 & -0.000393 & -0.038301 \\
\hline & $(0.266)$ & $(0.269)$ & $(0.010)$ & $(0.005)$ & $(0.035)$ & $(0.593)$ & $(0.310)$ & $(0.951)$ & $(0.438)$ & $(0.141)$ \\
\hline \multirow[t]{2}{*}{ Number of portfolios } & $0.000088^{*}$ & $0.000090^{*}$ & $0.000082 * *$ & $0.000093^{* *}$ & $0.016889 * * *$ & -0.000874 & -0.001539 & $-0.097463 *$ & -0.000273 & 0.006275 \\
\hline & $(0.071)$ & $(0.069)$ & $(0.019)$ & $(0.010)$ & $(0.003)$ & $(0.804)$ & $(0.651)$ & $(0.070)$ & $(0.478)$ & $(0.670)$ \\
\hline \multirow[t]{2}{*}{ Portfolio size (July 2013) } & -0.000000 & -0.000000 & -0.000000 & -0.000000 & -0.000000 & $0.000000^{* * *}$ & $0.000000^{*}$ & 0.000000 & 0.000000 & $-0.000000 * *$ \\
\hline & $(0.719)$ & $(0.723)$ & $(0.461)$ & $(0.686)$ & $(0.946)$ & $(0.020)$ & $(0.061)$ & $(0.437)$ & $(0.674)$ & $(0.026)$ \\
\hline \multirow[t]{2}{*}{ Job dummy 1} & -0.000427 & -0.000423 & -0.000163 & -0.000151 & -0.023428 & 0.003322 & 0.001533 & -0.217304 & -0.002779 & 0.056489 \\
\hline & $(0.244)$ & $(0.260)$ & $(0.427)$ & $(0.487)$ & $(0.463)$ & $(0.817)$ & $(0.934)$ & $(0.451)$ & $(0.299)$ & $(0.656)$ \\
\hline \multirow[t]{2}{*}{ Job dummy2 } & -0.000014 & -0.000003 & 0.000001 & 0.000041 & 0.003762 & 0.025837 & -0.016170 & 0.634513 & -0.000690 & 0.075557 \\
\hline & $(0.939)$ & $(0.989)$ & $(0.995)$ & (0.807) & $(0.876)$ & $(0.143)$ & $(0.481)$ & $(0.266)$ & $(0.860)$ & $(0.596)$ \\
\hline \multirow[t]{2}{*}{ Job dummy3 } & -0.000080 & -0.000076 & -0.000050 & -0.000028 & -0.001269 & 0.014674 & -0.002664 & -0.258205 & -0.003787 & 0.049421 \\
\hline & $(0.533)$ & $(0.571)$ & $(0.697)$ & $(0.830)$ & $(0.946)$ & $(0.261)$ & $(0.875)$ & $(0.345)$ & (0.146) & $(0.691)$ \\
\hline \multirow[t]{2}{*}{ Job dummy4 } & -0.000127 & -0.000127 & -0.000167 & -0.000141 & -0.031619 & 0.006301 & 0.004402 & -0.088851 & -0.002015 & -0.048676 \\
\hline & $(0.408)$ & $(0.424)$ & $(0.291)$ & $(0.375)$ & $(0.218)$ & $(0.653)$ & $(0.812)$ & $(0.748)$ & $(0.444)$ & $(0.718)$ \\
\hline \multirow[t]{2}{*}{ Constant } & 0.000522 & 0.000519 & $0.001076^{* *}$ & $0.001074 * *$ & 0.105182 & $0.084760^{* *}$ & -0.027616 & $1.072367 *$ & $0.007111 *$ & -0.411006 \\
\hline & $(0.338)$ & $(0.352)$ & $(0.021)$ & $(0.023)$ & $(0.163)$ & $(0.021)$ & $(0.557)$ & $(0.082)$ & $(0.070)$ & $(0.545)$ \\
\hline Observations & 3,032 & 3,032 & 3,032 & 3,032 & 3,032 & 3,032 & 3,032 & 3,032 & 3,032 & 3,032 \\
\hline R-squared & 0.003 & 0.003 & 0.003 & 0.004 & 0.004 & 0.012 & 0.002 & 0.010 & 0.005 & 0.011 \\
\hline
\end{tabular}


Table 9: Effect of Securities Account Reports (18 months after first distribution, investors that trade within 5 days)

This table displays the results for the difference-in-differences analysis from August 2013 to end of January 2015 (18 months) for investors who trade within five days after the distribution of the reports. The columns (1) to (5) measure changes in portfolio performance, columns (6) and (7) changes in diversification, and columns (8) and (9) measure changes in trading behavior. The $p$-values from using clustered standard errors are displayed in parentheses, with ***,**, and * denoting significance at the $1 \%, 5 \%$, and $10 \%$ levels, respectively.

\begin{tabular}{|c|c|c|c|c|c|c|c|c|c|c|}
\hline \multirow[b]{3}{*}{ Variables } & \multicolumn{5}{|c|}{ Return / Performance } & \multicolumn{2}{|c|}{ Diversification } & \multicolumn{2}{|c|}{ Trading } & \multirow{2}{*}{$\begin{array}{c}\text { Investment } \\
(10)\end{array}$} \\
\hline & (1) & $(2)$ & (3) & (4) & $(5)$ & (6) & (7) & $(8)$ & (9) & \\
\hline & Return & Net- Return & $\begin{array}{c}\text { Alpha (gross) } \\
\text { (1-factor) }\end{array}$ & $\begin{array}{c}\text { Alpha (gross) } \\
\text { (4-factor) }\end{array}$ & Sharpe Ratio & $\begin{array}{c}\text { Unsys. var. } \\
\text { (4-factor) }\end{array}$ & HHI & Fees & Turnover & Size of portfolio \\
\hline \multirow[t]{2}{*}{ Report } & $0.000587 * * *$ & $0.000616^{* * *}$ & $0.000467 * *$ & $0.000488^{* * * *}$ & $0.093428 * * *$ & $-0.022655^{* * *}$ & $-0.030917 * * *$ & -0.118263 & $-0.002849 * * *$ & $0.132479 * *$ \\
\hline & $(0.004)$ & $(0.004)$ & $(0.013)$ & $(0.009)$ & $(0.008)$ & $(0.006)$ & $(0.003)$ & $(0.494)$ & $(0.007)$ & $(0.041)$ \\
\hline \multirow[t]{2}{*}{ Age } & -0.000039 & -0.000040 & -0.000044 & -0.000040 & -0.007818 & -0.000462 & -0.000196 & -0.003407 & -0.000079 & $0.022202 *$ \\
\hline & $(0.163)$ & $(0.163)$ & $(0.140)$ & $(0.175)$ & $(0.180)$ & $(0.773)$ & $(0.925)$ & $(0.925)$ & $(0.679)$ & $(0.085)$ \\
\hline \multirow[t]{2}{*}{$\operatorname{Age}^{\wedge} 2$} & 0.000000 & 0.000000 & 0.000000 & 0.000000 & 0.000070 & -0.000003 & -0.000007 & -0.000014 & 0.000000 & -0.000212 \\
\hline & $(0.114)$ & $(0.118)$ & $(0.133)$ & (0.164) & $(0.200)$ & $(0.830)$ & $(0.740)$ & $(0.966)$ & $(0.833)$ & $(0.110)$ \\
\hline \multirow{2}{*}{ Gender } & 0.000009 & 0.000033 & -0.000023 & -0.000039 & -0.013615 & $-0.031262 * *$ & -0.015209 & -0.757286 & -0.001986 & 0.007976 \\
\hline & $(0.951)$ & $(0.828)$ & $(0.875)$ & $(0.787)$ & $(0.543)$ & $(0.025)$ & $(0.449)$ & $(0.248)$ & $(0.603)$ & $(0.945)$ \\
\hline \multirow[t]{2}{*}{ Risk-class (WpHG) } & $-0.000179 * *$ & $-0.000187 * *$ & $-0.000253^{* * *}$ & $-0.000219 * * *$ & $-0.038137 * *$ & $0.009642 *$ & -0.004066 & 0.061475 & 0.000085 & 0.061620 \\
\hline & $(0.012)$ & $(0.010)$ & $(0.002)$ & $(0.006)$ & $(0.015)$ & $(0.076)$ & $(0.593)$ & $(0.546)$ & $(0.907)$ & $(0.127)$ \\
\hline \multirow[t]{2}{*}{ Number of portfolios } & $0.000153 * *$ & $0.000158 * *$ & $0.000156^{* *}$ & $0.000151^{* *}$ & $0.033062 * * *$ & 0.000738 & -0.005084 & -0.117120 & -0.000396 & 0.013486 \\
\hline & $(0.018)$ & $(0.018)$ & $(0.013)$ & $(0.014)$ & $(0.004)$ & $(0.867)$ & $(0.269)$ & $(0.122)$ & $(0.398)$ & $(0.648)$ \\
\hline \multirow[t]{2}{*}{ Portfolio size (July 2013) } & 0.000000 & 0.000000 & 0.000000 & 0.000000 & 0.000000 & $0.000000^{* * *}$ & $0.000000 * *$ & 0.000001 & 0.000000 & 0.000000 \\
\hline & $(0.591)$ & $(0.586)$ & $(0.652)$ & $(0.810)$ & $(0.342)$ & $(0.001)$ & $(0.021)$ & $(0.138)$ & $(0.440)$ & $(0.903)$ \\
\hline \multirow[t]{2}{*}{ Job dummy1 } & -0.000124 & -0.000122 & 0.000050 & -0.000103 & 0.009033 & 0.009591 & 0.031314 & -0.327894 & -0.004569 & 0.052600 \\
\hline & $(0.801)$ & $(0.809)$ & $(0.881)$ & $(0.749)$ & $(0.833)$ & $(0.591)$ & $(0.259)$ & $(0.362)$ & $(0.143)$ & $(0.753)$ \\
\hline \multirow[t]{2}{*}{ Job dummy 2} & 0.000111 & 0.000104 & 0.000021 & -0.000088 & 0.012283 & 0.029681 & 0.025366 & 0.680454 & -0.003755 & -0.177523 \\
\hline & $(0.690)$ & $(0.715)$ & (0.937) & $(0.714)$ & $(0.736)$ & $(0.180)$ & $(0.420)$ & $(0.370)$ & $(0.439)$ & (0.334) \\
\hline \multirow[t]{2}{*}{ Job dummy3 } & 0.000225 & 0.000236 & 0.000186 & 0.000068 & 0.027758 & 0.013680 & 0.019125 & -0.464324 & $-0.006601 * *$ & -0.061152 \\
\hline & $(0.334)$ & $(0.327)$ & $(0.414)$ & $(0.722)$ & $(0.367)$ & $(0.398)$ & $(0.462)$ & $(0.187)$ & $(0.031)$ & $(0.698)$ \\
\hline \multirow[t]{2}{*}{ Job dummy4 } & -0.000171 & -0.000167 & -0.000305 & -0.000373 & -0.073577 & 0.017952 & 0.019766 & -0.413387 & $-0.005208^{*}$ & -0.128529 \\
\hline & $(0.533)$ & $(0.553)$ & $(0.344)$ & $(0.199)$ & $(0.211)$ & $(0.310)$ & $(0.471)$ & $(0.223)$ & $(0.093)$ & $(0.439)$ \\
\hline \multirow[t]{2}{*}{ Constant } & 0.000719 & 0.000737 & $0.001929 * *$ & $0.001851^{* *}$ & 0.248021 & -0.046064 & 0.074837 & 1.323398 & $0.012667 * *$ & -0.450942 \\
\hline & $(0.340)$ & $(0.340)$ & $(0.032)$ & $(0.037)$ & $(0.177)$ & $(0.331)$ & $(0.220)$ & (0.199) & $(0.032)$ & $(0.197)$ \\
\hline Observations & 2,322 & 2,322 & 2,322 & 2,322 & 2,322 & 2,322 & 2,322 & 2,322 & 2,322 & 2,322 \\
\hline R-squared & 0.007 & 0.007 & 0.008 & 0.007 & 0.009 & 0.013 & 0.010 & 0.016 & 0.010 & 0.007 \\
\hline
\end{tabular}


Table 10: Effect of Securities Account Reports (18 months after first distribution, high fees)

This table displays the results for the difference-in-differences analysis from August 2013 to end of January 2015 (18 months) for investors who have above median fees for the twelve months prior to 31 July 2013. The columns (1) to (5) measure changes in portfolio performance, columns (6) and (7) changes in diversification, and columns (8) and (9) measure changes in trading behavior. The $p$-values from using clustered standard errors are displayed in parentheses, with $* * *, * *$, and $*$ denoting significance at the $1 \%, 5 \%$, and $10 \%$ levels, respectively.

\begin{tabular}{|c|c|c|c|c|c|c|c|c|c|c|}
\hline \multirow[b]{3}{*}{ Variables } & \multicolumn{5}{|c|}{ Return / Performance } & \multicolumn{2}{|c|}{ Diversification } & \multicolumn{2}{|c|}{ Trading } & \multirow{2}{*}{$\begin{array}{c}\text { Investment } \\
(10)\end{array}$} \\
\hline & (1) & (2) & (3) & (4) & (5) & (6) & (7) & $(8)$ & (9) & \\
\hline & Return & Net- Return & $\begin{array}{l}\text { Alpha (gross) } \\
\text { (1-factor) }\end{array}$ & $\begin{array}{c}\text { Alpha (gross) } \\
\text { (4-factor) }\end{array}$ & Sharpe Ratio & $\begin{array}{l}\text { Unsys. var. } \\
\text { (4-factor) }\end{array}$ & HHI & Fees & Turnover & Size of portfolio \\
\hline \multirow[t]{2}{*}{ Report } & $0.000485^{* *}$ & $0.000528 * *$ & 0.000364 & $0.000401^{*}$ & $0.074671 *$ & -0.014733 & $-0.026252 * *$ & -0.246390 & $-0.005853 * * *$ & 0.093430 \\
\hline & $(0.047)$ & $(0.035)$ & $(0.121)$ & $(0.085)$ & $(0.093)$ & $(0.113)$ & $(0.025)$ & $(0.255)$ & $(0.000)$ & $(0.212)$ \\
\hline \multirow[t]{2}{*}{ Age } & -0.000023 & -0.000025 & -0.000026 & -0.000022 & -0.004958 & -0.001619 & -0.001857 & -0.008351 & -0.000025 & $0.049439 * * *$ \\
\hline & $(0.532)$ & $(0.493)$ & $(0.501)$ & $(0.559)$ & $(0.516)$ & $(0.352)$ & $(0.376)$ & $(0.852)$ & $(0.907)$ & $(0.000)$ \\
\hline \multirow[t]{2}{*}{$\mathrm{Age}^{\wedge} 2$} & 0.000000 & 0.000000 & 0.000000 & 0.000000 & 0.000053 & 0.000009 & 0.000007 & 0.000023 & -0.000000 & $-0.000482 * * *$ \\
\hline & (0.307) & $(0.290)$ & $(0.372)$ & $(0.417)$ & $(0.439)$ & $(0.617)$ & $(0.717)$ & $(0.953)$ & $(0.977)$ & $(0.001)$ \\
\hline \multirow[t]{2}{*}{ Gender } & -0.000070 & -0.000042 & -0.000073 & -0.000088 & -0.031628 & $-0.033793^{*}$ & -0.017731 & -1.066928 & -0.002420 & 0.121624 \\
\hline & $(0.718)$ & $(0.833)$ & $(0.705)$ & $(0.633)$ & $(0.284)$ & $(0.054)$ & $(0.458)$ & $(0.218)$ & $(0.630)$ & $(0.337)$ \\
\hline \multirow[t]{2}{*}{ Risk-class (WpHG) } & $-0.000317 * * *$ & $-0.000325^{* * *}$ & $-0.000435^{* * *}$ & $-0.000393^{* * *}$ & $-0.064975^{* * *}$ & $0.017368 * * *$ & -0.001706 & -0.031060 & -0.000423 & 0.043380 \\
\hline & $(0.001)$ & $(0.001)$ & $(0.000)$ & $(0.000)$ & $(0.002)$ & $(0.010)$ & $(0.861)$ & $(0.828)$ & $(0.692)$ & $(0.378)$ \\
\hline \multirow[t]{2}{*}{ Number of portfolios } & $0.000163^{* *}$ & $0.000166^{* *}$ & $0.000166^{* *}$ & $0.000159^{* *}$ & $0.034730 * * *$ & -0.000014 & -0.001648 & -0.088096 & -0.000423 & 0.006384 \\
\hline & $(0.028)$ & $(0.028)$ & $(0.020)$ & $(0.025)$ & $(0.008)$ & $(0.998)$ & $(0.704)$ & $(0.311)$ & $(0.350)$ & $(0.819)$ \\
\hline \multirow[t]{2}{*}{ Portfolio size (July 2013) } & 0.000000 & 0.000000 & 0.000000 & 0.000000 & 0.000000 & $0.000000 * * *$ & $0.000000^{* *}$ & 0.000001 & 0.000000 & -0.000000 \\
\hline & $(0.349)$ & $(0.370)$ & $(0.311)$ & $(0.429)$ & $(0.154)$ & $(0.001)$ & $(0.035)$ & $(0.547)$ & $(0.162)$ & $(0.790)$ \\
\hline \multirow[t]{2}{*}{ Job dummy1 } & -0.000391 & -0.000373 & -0.000143 & -0.000310 & -0.019631 & 0.013682 & 0.044010 & -0.282822 & -0.001986 & -0.014342 \\
\hline & $(0.545)$ & $(0.574)$ & $(0.750)$ & $(0.470)$ & $(0.738)$ & $(0.524)$ & $(0.158)$ & $(0.578)$ & $(0.582)$ & $(0.943)$ \\
\hline \multirow[t]{2}{*}{ Job dummy 2} & 0.000160 & 0.000157 & 0.000134 & 0.000005 & 0.026574 & $0.044723^{*}$ & 0.032635 & 1.280852 & 0.000379 & -0.219393 \\
\hline & (0.661) & $(0.677)$ & $(0.712)$ & (0.988) & $(0.597)$ & $(0.083)$ & $(0.382)$ & (0.208) & $(0.951)$ & $(0.332)$ \\
\hline \multirow[t]{2}{*}{ Job dummy3 } & 0.000217 & 0.000232 & 0.000182 & 0.000059 & 0.025243 & 0.014621 & 0.032063 & -0.380007 & -0.004407 & -0.088127 \\
\hline & (0.496) & $(0.482)$ & $(0.566)$ & $(0.823)$ & $(0.572)$ & $(0.455)$ & $(0.278)$ & $(0.446)$ & (0.213) & $(0.648)$ \\
\hline \multirow[t]{2}{*}{ Job dummy4 } & -0.000292 & -0.000288 & -0.000494 & -0.000569 & -0.121770 & 0.011939 & 0.035988 & -0.212165 & -0.002203 & -0.076899 \\
\hline & (0.453) & $(0.470)$ & $(0.252)$ & $(0.141)$ & $(0.111)$ & $(0.565)$ & $(0.240)$ & $(0.655)$ & $(0.545)$ & $(0.693)$ \\
\hline \multirow[t]{2}{*}{ Constant } & 0.001074 & 0.001144 & $0.002478^{* *}$ & $0.002364 * *$ & 0.337772 & -0.068461 & 0.084189 & 2.072300 & 0.011553 & $-1.019233^{* * *}$ \\
\hline & $(0.243)$ & $(0.224)$ & $(0.029)$ & $(0.034)$ & $(0.150)$ & $(0.190)$ & $(0.205)$ & $(0.119)$ & $(0.105)$ & $(0.006)$ \\
\hline Observations & 1,803 & 1,803 & 1,803 & 1,803 & 1,803 & 1,803 & 1,803 & 1,803 & 1,803 & 1,803 \\
\hline R-squared & 0.008 & 0.008 & 0.009 & 0.008 & 0.009 & 0.016 & 0.011 & 0.014 & 0.017 & 0.011 \\
\hline
\end{tabular}


Table 11: Effect of Securities Account Reports (18 months after first distribution, information overload)

This table displays the results for the difference-in-differences analysis from August 2013 to end of January 2015 (18 months) for investors who have a financial literacy score above 3 . The columns (1) to (5) measure changes in portfolio performance, columns (6) and (7) changes in diversification, and columns (8) and (9) measure changes in trading behavior. The $p$-values from using clustered standard errors are displayed in parentheses, with $* * *, * *$, and $*$ denoting significance at the $1 \%, 5 \%$, and $10 \%$ levels, respectively.

\begin{tabular}{|c|c|c|c|c|c|c|c|c|c|c|}
\hline \multirow[b]{3}{*}{ Variables } & \multicolumn{5}{|c|}{ Return / Performance } & \multicolumn{2}{|c|}{ Diversification } & \multicolumn{2}{|c|}{ Trading } & \multirow{2}{*}{$\begin{array}{c}\text { Investment } \\
(10)\end{array}$} \\
\hline & (1) & (2) & (3) & (4) & $(5)$ & (6) & (7) & $(8)$ & (9) & \\
\hline & Return & Net- Return & $\begin{array}{c}\text { Alpha (gross) } \\
\text { (1-factor) }\end{array}$ & $\begin{array}{c}\text { Alpha (gross) } \\
\text { (4-factor) }\end{array}$ & Sharpe Ratio & $\begin{array}{l}\text { Unsys. var. } \\
\text { (4-factor) }\end{array}$ & HHI & Fees & Turnover & Size of portfolio \\
\hline \multirow[t]{2}{*}{ Report } & $0.000511 * * *$ & $0.000536^{* * * *}$ & $0.000381 * * *$ & $0.000400 * * *$ & $0.065708^{* * *}$ & $-0.021046^{* * *}$ & $-0.020448 * *$ & 0.070292 & $-0.001842 * *$ & 0.057195 \\
\hline & $(0.004)$ & $(0.004)$ & $(0.003)$ & $(0.003)$ & $(0.001)$ & $(0.006)$ & $(0.032)$ & $(0.594)$ & $(0.025)$ & $(0.340)$ \\
\hline \multirow[t]{2}{*}{ Age } & -0.000028 & -0.000029 & -0.000027 & -0.000025 & -0.003664 & -0.001753 & -0.000737 & -0.016309 & -0.000034 & $0.020469 *$ \\
\hline & $(0.235)$ & $(0.215)$ & $(0.161)$ & $(0.212)$ & $(0.267)$ & $(0.226)$ & $(0.674)$ & $(0.559)$ & $(0.810)$ & $(0.094)$ \\
\hline \multirow[t]{2}{*}{$\mathrm{Age}^{\wedge} 2$} & 0.000000 & 0.000000 & 0.000000 & 0.000000 & 0.000032 & 0.000010 & -0.000003 & 0.000142 & -0.000000 & -0.000207 \\
\hline & $(0.227)$ & $(0.207)$ & $(0.202)$ & $(0.256)$ & $(0.352)$ & $(0.486)$ & $(0.855)$ & $(0.585)$ & $(0.979)$ & $(0.107)$ \\
\hline \multirow[t]{2}{*}{ Gender } & -0.000138 & -0.000127 & -0.000140 & -0.000144 & -0.018520 & $-0.030710^{* *}$ & -0.022034 & -0.025208 & 0.003353 & -0.016417 \\
\hline & $(0.273)$ & $(0.334)$ & $(0.252)$ & $(0.226)$ & $(0.289)$ & $(0.025)$ & $(0.243)$ & $(0.918)$ & $(0.156)$ & $(0.874)$ \\
\hline \multirow[t]{2}{*}{ Risk-class (WpHG) } & $-0.000169 * * *$ & $-0.000175^{* * *}$ & $-0.000191 * * *$ & $-0.000162 * * *$ & $-0.024663 * * *$ & $0.011373 * *$ & 0.004383 & 0.029981 & -0.000210 & 0.047891 \\
\hline & $(0.006)$ & $(0.006)$ & $(0.000)$ & $(0.003)$ & $(0.004)$ & $(0.032)$ & $(0.509)$ & $(0.678)$ & $(0.720)$ & $(0.202)$ \\
\hline \multirow[t]{2}{*}{ Number of portfolios } & $0.000152 * * *$ & $0.000155^{* * *}$ & $0.000125^{* * *}$ & $0.000125^{* * *}$ & $0.023657 * * *$ & 0.002671 & -0.000080 & -0.074491 & -0.000309 & -0.007469 \\
\hline & $(0.008)$ & $(0.008)$ & $(0.004)$ & $(0.005)$ & $(0.000)$ & $(0.509)$ & $(0.984)$ & $(0.190)$ & $(0.385)$ & $(0.779)$ \\
\hline \multirow[t]{2}{*}{ Portfolio size (July 2013) } & 0.000000 & 0.000000 & 0.000000 & 0.000000 & 0.000000 & $0.000000 * * *$ & $0.000000 *$ & 0.000001 & 0.000000 & 0.000000 \\
\hline & $(0.229)$ & $(0.225)$ & $(0.406)$ & $(0.538)$ & $(0.218)$ & $(0.002)$ & $(0.089)$ & $(0.450)$ & $(0.677)$ & $(0.803)$ \\
\hline \multirow[t]{2}{*}{ Job dummy1 } & -0.000309 & -0.000306 & -0.000096 & -0.000240 & -0.025120 & 0.012081 & $0.049438 * *$ & -0.277461 & -0.001987 & -0.046486 \\
\hline & $(0.484)$ & (0.499) & $(0.750)$ & $(0.410)$ & $(0.506)$ & $(0.464)$ & $(0.041)$ & $(0.366)$ & $(0.434)$ & $(0.755)$ \\
\hline \multirow[t]{2}{*}{ Job dummy2 } & 0.000041 & 0.000043 & 0.000038 & -0.000063 & 0.001348 & 0.026700 & 0.021604 & 0.246982 & -0.003927 & -0.195383 \\
\hline & $(0.873)$ & $(0.870)$ & $(0.880)$ & $(0.778)$ & $(0.967)$ & $(0.172)$ & $(0.438)$ & $(0.496)$ & $(0.235)$ & $(0.231)$ \\
\hline \multirow[t]{2}{*}{ Job dummy3 } & 0.000088 & 0.000095 & 0.000097 & -0.000018 & 0.003723 & 0.018291 & 0.027293 & -0.407074 & -0.003945 & -0.096122 \\
\hline & $(0.683)$ & $(0.668)$ & $(0.643)$ & $(0.919)$ & $(0.892)$ & $(0.212)$ & $(0.221)$ & $(0.165)$ & $(0.107)$ & $(0.494)$ \\
\hline \multirow[t]{2}{*}{ Job dummy4 } & -0.000143 & -0.000145 & -0.000042 & -0.000126 & -0.034840 & 0.020382 & 0.033624 & -0.352746 & -0.002951 & -0.132743 \\
\hline & $(0.538)$ & $(0.545)$ & $(0.856)$ & $(0.533)$ & (0.314) & $(0.210)$ & (0.149) & $(0.215)$ & $(0.243)$ & $(0.363)$ \\
\hline \multirow[t]{2}{*}{ Constant } & 0.000753 & 0.000789 & $0.001428 * * *$ & $0.001409 * * *$ & 0.121942 & -0.035040 & 0.027932 & 0.854675 & 0.005455 & -0.142603 \\
\hline & $(0.200)$ & $(0.188)$ & $(0.003)$ & $(0.005)$ & $(0.138)$ & $(0.416)$ & $(0.581)$ & $(0.290)$ & $(0.213)$ & $(0.659)$ \\
\hline Observations & 2,558 & 2,558 & 2,558 & 2,558 & 2,558 & 2,558 & 2,558 & 2,558 & 2,558 & 2,558 \\
\hline R-squared & 0.007 & 0.007 & 0.008 & 0.008 & 0.010 & 0.012 & 0.009 & 0.007 & 0.008 & 0.003 \\
\hline
\end{tabular}


Table 12: Effect of Securities Account Reports (18 months after first distribution, attrition)

This table displays the results for the difference-in-differences analysis from August 2013 to end of January 2015 (18 months) for investors who have not traded after the reception of the first report. The columns (1) to (5) measure changes in portfolio performance, columns (6) and (7) changes in diversification, and columns (8) and (9) measure changes in trading behavior. The $p$-values from using clustered standard errors are displayed in parentheses, with ***,**, and * denoting significance at the $1 \%, 5 \%$, and $10 \%$ levels, respectively.

\begin{tabular}{|c|c|c|c|c|c|c|c|c|c|c|}
\hline \multirow[b]{3}{*}{ Variables } & \multicolumn{5}{|c|}{ Return / Performance } & \multicolumn{2}{|c|}{ Diversification } & \multicolumn{2}{|c|}{ Trading } & \multirow{2}{*}{$\begin{array}{c}\text { Investment } \\
(10)\end{array}$} \\
\hline & $(1)$ & $(2)$ & (3) & (4) & $(5)$ & (6) & $(7)$ & $(8)$ & (9) & \\
\hline & Return & Net- Return & $\begin{array}{c}\text { Alpha (gross) } \\
\text { (1-factor) }\end{array}$ & $\begin{array}{c}\text { Alpha (gross) } \\
\text { (4-factor) }\end{array}$ & Sharpe Ratio & $\begin{array}{c}\text { Unsys. var. } \\
\text { (4-factor) }\end{array}$ & HHI & Fees & Turnover & Size of portfolio \\
\hline \multirow[t]{2}{*}{ Report } & $0.000436^{* * *}$ & $0.000460 * * *$ & $0.000347 * *$ & $0.000366^{* *}$ & $0.066019 * *$ & $-0.021023^{* * *}$ & $-0.019734^{* *}$ & -0.097335 & $-0.002722 * * *$ & -0.002533 \\
\hline & $(0.009)$ & $(0.007)$ & $(0.022)$ & $(0.016)$ & $(0.017)$ & $(0.003)$ & $(0.027)$ & $(0.471)$ & $(0.001)$ & $(0.583)$ \\
\hline \multirow[t]{2}{*}{ Age } & -0.000020 & -0.000021 & -0.000022 & -0.000019 & -0.003772 & -0.001674 & -0.000119 & -0.000472 & -0.000013 & 0.001034 \\
\hline & $(0.412)$ & $(0.395)$ & $(0.360)$ & $(0.430)$ & $(0.416)$ & $(0.233)$ & $(0.943)$ & $(0.986)$ & $(0.927)$ & $(0.380)$ \\
\hline \multirow{2}{*}{$\operatorname{Age}^{\wedge} 2$} & 0.000000 & 0.000000 & 0.000000 & 0.000000 & 0.000036 & 0.000008 & -0.000009 & -0.000025 & -0.000000 & -0.000013 \\
\hline & $(0.255)$ & $(0.249)$ & $(0.294)$ & $(0.351)$ & $(0.395)$ & $(0.562)$ & $(0.566)$ & $(0.919)$ & $(0.865)$ & $(0.297)$ \\
\hline \multirow{2}{*}{ Gender } & -0.000035 & -0.000018 & -0.000046 & -0.000059 & -0.013732 & $-0.023169 *$ & -0.008381 & -0.569268 & -0.000826 & -0.003643 \\
\hline & $(0.769)$ & $(0.884)$ & $(0.695)$ & $(0.601)$ & $(0.429)$ & $(0.062)$ & $(0.610)$ & $(0.262)$ & $(0.779)$ & $(0.624)$ \\
\hline \multirow[t]{2}{*}{ Risk-class (WpHG) } & $-0.000186^{* * *}$ & $-0.000191 * * *$ & $-0.000250 * * *$ & $-0.000219 * * *$ & $-0.035590 * * *$ & $0.009154 *$ & -0.000380 & 0.057252 & -0.000025 & 0.002249 \\
\hline & $(0.003)$ & $(0.002)$ & $(0.000)$ & $(0.001)$ & $(0.003)$ & $(0.060)$ & $(0.951)$ & $(0.453)$ & $(0.965)$ & $(0.510)$ \\
\hline \multirow[t]{2}{*}{ Number of portfolios } & $0.000133 * *$ & $0.000137 * *$ & $0.000127^{* *}$ & $0.000123 * *$ & $0.026479 * * *$ & 0.000793 & -0.001536 & -0.091958 & -0.000328 & 0.000044 \\
\hline & $(0.013)$ & $(0.012)$ & $(0.010)$ & $(0.012)$ & $(0.003)$ & $(0.838)$ & $(0.694)$ & $(0.129)$ & $(0.364)$ & $(0.985)$ \\
\hline \multirow[t]{2}{*}{ Portfolio size (July 2013) } & 0.000000 & 0.000000 & 0.000000 & 0.000000 & 0.000000 & $0.000000 * * *$ & $0.000000 * *$ & 0.000000 & 0.000000 & 0.000000 \\
\hline & $(0.371)$ & $(0.369)$ & $(0.429)$ & $(0.583)$ & $(0.215)$ & $(0.001)$ & $(0.046)$ & $(0.536)$ & $(0.763)$ & $(0.646)$ \\
\hline \multirow[t]{2}{*}{ Job dummy1 } & -0.000283 & -0.000280 & -0.000102 & -0.000217 & -0.016292 & 0.007662 & 0.026565 & -0.199079 & -0.002551 & 0.005530 \\
\hline & $(0.464)$ & $(0.480)$ & $(0.700)$ & $(0.400)$ & $(0.629)$ & $(0.621)$ & $(0.230)$ & $(0.489)$ & $(0.308)$ & $(0.635)$ \\
\hline \multirow[t]{2}{*}{ Job dummy 2} & -0.000006 & -0.000015 & -0.000036 & -0.000122 & -0.000092 & 0.025701 & 0.015991 & 0.829317 & -0.000598 & 0.003350 \\
\hline & (0.978) & (0.948) & $(0.869)$ & $(0.538)$ & (0.998) & $(0.168)$ & $(0.528)$ & $(0.166)$ & $(0.877)$ & $(0.787)$ \\
\hline \multirow[t]{2}{*}{ Job dummy3 } & 0.000037 & 0.000042 & 0.000059 & -0.000029 & 0.005540 & 0.014912 & 0.016357 & -0.297026 & $-0.004077^{*}$ & -0.000761 \\
\hline & $(0.846)$ & $(0.829)$ & $(0.747)$ & $(0.855)$ & $(0.822)$ & $(0.284)$ & $(0.423)$ & $(0.283)$ & $(0.095)$ & $(0.944)$ \\
\hline \multirow[t]{2}{*}{ Job dummy4 } & -0.000373 & -0.000373 & -0.000415 & $-0.000459 *$ & $-0.091034^{*}$ & 0.013754 & 0.019041 & -0.224533 & -0.002991 & 0.011522 \\
\hline & $(0.133)$ & $(0.141)$ & $(0.137)$ & $(0.076)$ & $(0.071)$ & $(0.365)$ & $(0.374)$ & $(0.402)$ & $(0.228)$ & $(0.307)$ \\
\hline \multirow[t]{2}{*}{ Constant } & 0.000585 & 0.000606 & $0.001585^{* *}$ & $0.001509 * *$ & 0.171849 & -0.022641 & 0.040216 & 0.858025 & $0.008091 *$ & -0.029146 \\
\hline & $(0.327)$ & $(0.321)$ & $(0.019)$ & $(0.024)$ & $(0.200)$ & $(0.584)$ & $(0.399)$ & $(0.244)$ & $(0.062)$ & $(0.219)$ \\
\hline Observations & 3,025 & 3,025 & 3,025 & 3,025 & 3,025 & 3,025 & 3,025 & 3,025 & 3,025 & 3,025 \\
\hline R-squared & 0.007 & 0.007 & 0.007 & 0.006 & 0.007 & 0.011 & 0.007 & 0.010 & 0.008 & 0.003 \\
\hline
\end{tabular}


Table 13: Effect of Securities Account Reports (18 months after first distribution, main account)

This table displays the results for the difference-in-differences analysis from August 2013 to end of January 2015 (18 months) for investors who report this account to be their main securities account. The columns (1) to (5) measure changes in portfolio performance, columns (6) and (7) changes in diversification, and columns (8) and (9) measure changes in trading behavior. The $p$-values from using clustered standard errors are displayed in parentheses, with ***,**, and * denoting significance at the $1 \%, 5 \%$, and $10 \%$ levels, respectively.

\begin{tabular}{|c|c|c|c|c|c|c|c|c|c|c|}
\hline \multirow[b]{3}{*}{ Variables } & \multicolumn{5}{|c|}{ Return / Performance } & \multicolumn{2}{|c|}{ Diversification } & \multicolumn{2}{|c|}{ Trading } & \multirow{2}{*}{$\begin{array}{c}\text { Investment } \\
(10)\end{array}$} \\
\hline & $(1)$ & (2) & (3) & (4) & (5) & $(6)$ & $(7)$ & $(8)$ & (9) & \\
\hline & Return & Net- Return & $\begin{array}{c}\text { Alpha (gross) } \\
\text { (1-factor) }\end{array}$ & $\begin{array}{c}\text { Alpha (gross) } \\
\text { (4-factor) }\end{array}$ & Sharpe Ratio & $\begin{array}{l}\text { Unsys. var. } \\
\text { (4-factor) }\end{array}$ & HHI & Fees & Turnover & Size of portfolio \\
\hline \multirow[t]{2}{*}{ Report } & $0.000476^{* *}$ & $0.000504 * *$ & $0.000337^{* *}$ & $0.000348 * *$ & $0.055316^{* * *}$ & $-0.026975 * * *$ & $-0.022150 * *$ & -0.026896 & $-0.002450 * * *$ & 0.065668 \\
\hline & $(0.016)$ & $(0.012)$ & $(0.019)$ & $(0.020)$ & (0.009) & $(0.001)$ & $(0.039)$ & $(0.859)$ & $(0.009)$ & $(0.317)$ \\
\hline \multirow[t]{2}{*}{ Age } & -0.000034 & -0.000035 & -0.000030 & -0.000025 & -0.003239 & $-0.002876^{*}$ & -0.000801 & -0.009508 & -0.000021 & $0.024769^{*}$ \\
\hline & $(0.212)$ & $(0.212)$ & $(0.164)$ & $(0.255)$ & $(0.377)$ & $(0.064)$ & $(0.687)$ & $(0.768)$ & $(0.898)$ & $(0.057)$ \\
\hline \multirow[t]{2}{*}{$\mathrm{Age}^{\wedge} 2$} & 0.000000 & 0.000000 & 0.000000 & 0.000000 & 0.000029 & 0.000021 & -0.000003 & 0.000068 & -0.000001 & $-0.000256^{*}$ \\
\hline & $(0.176)$ & $(0.176)$ & $(0.167)$ & $(0.250)$ & $(0.443)$ & $(0.182)$ & $(0.882)$ & $(0.818)$ & $(0.743)$ & $(0.065)$ \\
\hline \multirow[t]{2}{*}{ Gender } & -0.000023 & -0.000004 & 0.000023 & 0.000013 & 0.001149 & $-0.028720 * *$ & -0.013019 & -0.125350 & 0.001337 & -0.033314 \\
\hline & $(0.876)$ & $(0.978)$ & $(0.870)$ & $(0.922)$ & $(0.952)$ & $(0.045)$ & $(0.530)$ & $(0.606)$ & $(0.414)$ & $(0.756)$ \\
\hline \multirow[t]{2}{*}{ Risk-class (WpHG) } & $-0.000254 * * *$ & $-0.000259 * * *$ & $-0.000260 * * *$ & $-0.000232 * * *$ & $-0.035064 * * *$ & $0.013847 * *$ & 0.002109 & 0.084419 & 0.000184 & 0.051146 \\
\hline & $(0.001)$ & $(0.001)$ & $(0.000)$ & $(0.000)$ & $(0.000)$ & $(0.014)$ & $(0.782)$ & $(0.301)$ & $(0.785)$ & $(0.207)$ \\
\hline \multirow[t]{2}{*}{ Number of portfolios } & $0.000174 * *$ & $0.000175^{* *}$ & $0.000137 * * *$ & $0.000137 * * *$ & $0.024847 * * *$ & 0.005843 & -0.001220 & -0.062093 & 0.000255 & -0.002461 \\
\hline & $(0.015)$ & $(0.016)$ & $(0.008)$ & $(0.010)$ & $(0.001)$ & $(0.166)$ & $(0.799)$ & $(0.317)$ & $(0.523)$ & $(0.938)$ \\
\hline \multirow[t]{2}{*}{ Portfolio size (July 2013) } & 0.000000 & 0.000000 & 0.000000 & 0.000000 & 0.000000 & $0.000000 * * *$ & $0.000000 *$ & 0.000001 & 0.000000 & 0.000000 \\
\hline & $(0.202)$ & $(0.208)$ & $(0.338)$ & $(0.460)$ & $(0.214)$ & $(0.003)$ & $(0.054)$ & $(0.464)$ & $(0.308)$ & $(0.896)$ \\
\hline \multirow[t]{2}{*}{ Job dummy1 } & -0.000253 & -0.000247 & -0.000024 & -0.000199 & 0.000590 & 0.008510 & $0.047067 *$ & $-0.623852 *$ & -0.003362 & 0.061507 \\
\hline & $(0.630)$ & $(0.647)$ & $(0.944)$ & $(0.559)$ & (0.988) & $(0.641)$ & $(0.085)$ & $(0.080)$ & $(0.260)$ & $(0.711)$ \\
\hline \multirow[t]{2}{*}{ Job dummy2 } & 0.000071 & 0.000065 & 0.000032 & -0.000103 & 0.001351 & 0.032532 & 0.022611 & 0.231765 & -0.001600 & -0.126673 \\
\hline & (0.811) & $(0.830)$ & (0.909) & $(0.682)$ & $(0.971)$ & $(0.130)$ & $(0.470)$ & $(0.574)$ & $(0.616)$ & $(0.482)$ \\
\hline \multirow[t]{2}{*}{ Job dummy3 } & 0.000098 & 0.000107 & 0.000099 & -0.000041 & 0.003698 & 0.015153 & 0.023735 & $-0.598972 *$ & $-0.004871^{*}$ & -0.059616 \\
\hline & (0.694) & (0.679) & $(0.678)$ & $(0.839)$ & $(0.907)$ & $(0.355)$ & $(0.352)$ & $(0.087)$ & $(0.094)$ & $(0.706)$ \\
\hline \multirow[t]{2}{*}{ Job dummy4 } & -0.000281 & -0.000287 & -0.000154 & -0.000273 & -0.051512 & 0.020402 & 0.043104 & -0.536221 & -0.002973 & -0.150863 \\
\hline & $(0.311)$ & $(0.314)$ & $(0.571)$ & $(0.260)$ & $(0.209)$ & $(0.257)$ & $(0.108)$ & $(0.111)$ & $(0.318)$ & $(0.359)$ \\
\hline \multirow[t]{2}{*}{ Constant } & 0.001135 & 0.001144 & $0.001665^{* * *}$ & $0.001621 * * *$ & 0.146232 & -0.023318 & 0.035997 & 0.744382 & 0.005400 & -0.309135 \\
\hline & $(0.120)$ & $(0.127)$ & $(0.004)$ & $(0.007)$ & $(0.129)$ & $(0.614)$ & $(0.521)$ & $(0.434)$ & $(0.298)$ & $(0.361)$ \\
\hline Observations & 2,170 & 2,170 & 2,170 & 2,170 & 2,170 & 2,170 & 2,170 & 2,170 & 2,170 & 2,170 \\
\hline R-squared & 0.007 & 0.008 & 0.008 & 0.007 & 0.010 & 0.016 & 0.009 & 0.009 & 0.010 & 0.006 \\
\hline
\end{tabular}


Table 14: Effect of Securities Account Reports (18 months after first distribution, different report designs)

This table displays the results for the difference-in-differences analysis from August 2013 to end of January 2015 (18 months). The columns (1) to (5) measure changes in portfolio performance, columns (6) and (7) changes in diversification, and columns (8) and (9) measure changes in trading behavior. The $p$-values from using clustered standard errors are displayed in parentheses, with $* * *$, $* *$, and $*$ denoting significance at the $1 \%, 5 \%$, and $10 \%$ levels, respectively.

\begin{tabular}{|c|c|c|c|c|c|c|c|c|c|c|}
\hline \multirow[b]{3}{*}{ Variables } & \multicolumn{5}{|c|}{ Return / Performance } & \multicolumn{2}{|c|}{ Diversification } & \multicolumn{2}{|c|}{ Trading } & \multirow{2}{*}{$\begin{array}{c}\text { Investment } \\
(10)\end{array}$} \\
\hline & (1) & (2) & (3) & (4) & (5) & (6) & (7) & (8) & (9) & \\
\hline & Return & Net- Return & $\begin{array}{c}\text { Alpha (gross) } \\
\text { (1-factor) }\end{array}$ & $\begin{array}{c}\text { Alpha (gross) } \\
\text { (4-factor) }\end{array}$ & Sharpe Ratio & $\begin{array}{c}\text { Unsys. var. } \\
\text { (4-factor) }\end{array}$ & HHI & Fees & Turnover & Size of portfolio \\
\hline Report 1 & $\begin{array}{r}0.000289 \\
(0.112)\end{array}$ & $\begin{array}{r}0.000314^{*} \\
(0.090)\end{array}$ & $\begin{array}{r}0.000235 \\
(0.199)\end{array}$ & $\begin{array}{r}0.000239 \\
(0.199)\end{array}$ & $\begin{array}{r}0.057637^{*} \\
(0.062)\end{array}$ & $\begin{array}{r}-0.023779 * * \\
(0.035)\end{array}$ & $\begin{array}{r}-0.016818 \\
(0.193)\end{array}$ & $\begin{array}{r}-0.253594 \\
(0.117)\end{array}$ & $\begin{array}{r}-0.003474 * * * \\
(0.000)\end{array}$ & $\begin{array}{r}0.015932 \\
(0.852)\end{array}$ \\
\hline Report 2 & $\begin{array}{r}0.000481^{* *} \\
(0.011)\end{array}$ & $\begin{array}{r}0.000514^{* * * *} \\
(0.008)\end{array}$ & $\begin{array}{r}0.000395^{* *} \\
(0.022)\end{array}$ & $\begin{array}{r}0.000407 * * \\
(0.016)\end{array}$ & $\begin{array}{r}0.077341^{* *} \\
(0.010)\end{array}$ & $\begin{array}{r}-0.011868 \\
(0.283)\end{array}$ & $\begin{array}{r}-0.024548^{*} \\
(0.092)\end{array}$ & $\begin{array}{r}-0.112774 \\
(0.456)\end{array}$ & $\begin{array}{r}-0.003448^{* * * *} \\
(0.005)\end{array}$ & $\begin{array}{r}0.012456 \\
(0.888)\end{array}$ \\
\hline Report 3 & $\begin{array}{r}0.000381^{* *} \\
(0.044)\end{array}$ & $\begin{array}{r}0.000379^{* *} \\
(0.049)\end{array}$ & $\begin{array}{r}0.000326^{*} \\
(0.065)\end{array}$ & $\begin{array}{r}0.000345^{*} \\
(0.050)\end{array}$ & $\begin{array}{r}0.057854^{*} \\
(0.057)\end{array}$ & $\begin{array}{r}-0.036412 * * * \\
(0.002)\end{array}$ & $\begin{array}{r}-0.032499 * * \\
(0.026)\end{array}$ & $\begin{array}{r}0.048926 \\
(0.843)\end{array}$ & $\begin{array}{r}-0.000162 \\
(0.916)\end{array}$ & $\begin{array}{r}0.060663 \\
(0.442)\end{array}$ \\
\hline Report 4 & $\begin{array}{r}0.000588^{* *} \\
(0.022)\end{array}$ & $\begin{array}{r}0.000627^{* *} \\
(0.016)\end{array}$ & $\begin{array}{r}0.000428^{*} \\
(0.062)\end{array}$ & $\begin{array}{r}0.000471^{* *} \\
(0.036)\end{array}$ & $\begin{array}{r}0.069046^{*} \\
(0.097)\end{array}$ & $\begin{array}{r}-0.011037 \\
(0.324)\end{array}$ & $\begin{array}{r}-0.008839 \\
(0.550)\end{array}$ & $\begin{array}{r}-0.053891 \\
(0.766)\end{array}$ & $\begin{array}{r}-0.003724^{* *} \\
(0.012)\end{array}$ & $\begin{array}{r}0.128180 \\
(0.156)\end{array}$ \\
\hline Age & $\begin{array}{r}-0.000019 \\
(0.410)\end{array}$ & $\begin{array}{r}-0.000021 \\
(0.394)\end{array}$ & $\begin{array}{r}-0.000022 \\
(0.358)\end{array}$ & $\begin{array}{r}-0.000019 \\
(0.431)\end{array}$ & $\begin{array}{r}-0.003814 \\
(0.408)\end{array}$ & $\begin{array}{r}-0.001693 \\
(0.227)\end{array}$ & $\begin{array}{r}-0.000268 \\
(0.871)\end{array}$ & $\begin{array}{r}-0.000599 \\
(0.982)\end{array}$ & $\begin{array}{r}-0.000014 \\
(0.923)\end{array}$ & $\begin{array}{r}0.022306^{* *} \\
(0.043)\end{array}$ \\
\hline $\operatorname{Age}^{\wedge} 2$ & $\begin{array}{r}0.000000 \\
(0.253)\end{array}$ & $\begin{array}{r}0.000000 \\
(0.247)\end{array}$ & $\begin{array}{r}0.000000 \\
(0.292)\end{array}$ & $\begin{array}{r}0.000000 \\
(0.350)\end{array}$ & $\begin{array}{r}0.000037 \\
(0.387)\end{array}$ & $\begin{array}{r}0.000009 \\
(0.552)\end{array}$ & $\begin{array}{r}-0.000008 \\
(0.627)\end{array}$ & $\begin{array}{r}-0.000023 \\
(0.925)\end{array}$ & $\begin{array}{r}-0.000000 \\
(0.868)\end{array}$ & $\begin{array}{r}-0.000224^{* *} \\
(0.049)\end{array}$ \\
\hline Gender & $\begin{array}{r}-0.000023 \\
(0.844)\end{array}$ & $\begin{array}{r}-0.000006 \\
(0.959)\end{array}$ & $\begin{array}{r}-0.000035 \\
(0.766)\end{array}$ & $\begin{array}{r}-0.000047 \\
(0.681)\end{array}$ & $\begin{array}{r}-0.012973 \\
(0.459)\end{array}$ & $\begin{array}{r}-0.023643^{*} \\
(0.058)\end{array}$ & $\begin{array}{r}-0.011026 \\
(0.507)\end{array}$ & $\begin{array}{r}-0.559565 \\
(0.268)\end{array}$ & $\begin{array}{r}-0.000813 \\
(0.781)\end{array}$ & $\begin{array}{r}-0.024599 \\
(0.792)\end{array}$ \\
\hline Risk-class (WpHG) & $\begin{array}{r}-0.000185^{* * *} * \\
(0.003)\end{array}$ & $\begin{array}{r}-0.000190^{* * * *} \\
(0.002)\end{array}$ & $\begin{array}{r}-0.000250^{* * * *} \\
(0.000)\end{array}$ & $\begin{array}{r}-0.000219 * * * \\
(0.001)\end{array}$ & $\begin{array}{r}-0.035610^{* * * *} \\
(0.003)\end{array}$ & $\begin{array}{r}0.009130 * \\
(0.061)\end{array}$ & $\begin{array}{r}-0.000359 \\
(0.954)\end{array}$ & $\begin{array}{r}0.057557 \\
(0.449)\end{array}$ & $\begin{array}{r}-0.000030 \\
(0.957)\end{array}$ & $\begin{array}{r}0.040918 \\
(0.226)\end{array}$ \\
\hline Number of portfolios & $\begin{array}{r}0.000133^{* *} \\
(0.013)\end{array}$ & $\begin{array}{r}0.000136^{* *} \\
(0.012)\end{array}$ & $\begin{array}{r}0.000126^{* * *} \\
(0.011)\end{array}$ & $\begin{array}{r}0.000122^{* * *} \\
(0.013)\end{array}$ & $\begin{array}{r}0.026264 * * * \\
(0.003)\end{array}$ & $\begin{array}{r}0.000833 \\
(0.830)\end{array}$ & $\begin{array}{r}-0.001571 \\
(0.690)\end{array}$ & $\begin{array}{r}-0.093076 \\
(0.126)\end{array}$ & $\begin{array}{r}-0.000342 \\
(0.352)\end{array}$ & $\begin{array}{r}0.007568 \\
(0.767)\end{array}$ \\
\hline Portfolio size (July 2013) & $\begin{array}{r}0.000000 \\
(0.394)\end{array}$ & $\begin{array}{r}0.000000 \\
(0.391)\end{array}$ & $\begin{array}{r}0.000000 \\
(0.448)\end{array}$ & $\begin{array}{r}0.000000 \\
(0.608)\end{array}$ & $\begin{array}{r}0.000000 \\
(0.219)\end{array}$ & $\begin{array}{r}0.000000 * * * \\
(0.001)\end{array}$ & $\begin{array}{r}0.000000^{*} \\
(0.052)\end{array}$ & $\begin{array}{r}0.000000 \\
(0.540)\end{array}$ & $\begin{array}{r}0.000000 \\
(0.783)\end{array}$ & $\begin{array}{r}0.000000 \\
(0.808)\end{array}$ \\
\hline Job dummy1 & $\begin{array}{r}-0.000285 \\
(0.458)\end{array}$ & $\begin{array}{r}-0.000282 \\
(0.475)\end{array}$ & $\begin{array}{r}-0.000105 \\
(0.691)\end{array}$ & $\begin{array}{r}-0.000223 \\
(0.386)\end{array}$ & $\begin{array}{r}-0.015272 \\
(0.650)\end{array}$ & $\begin{array}{r}0.008654 \\
(0.577)\end{array}$ & $\begin{array}{r}0.028540 \\
(0.199)\end{array}$ & $\begin{array}{r}-0.216207 \\
(0.454)\end{array}$ & $\begin{array}{r}-0.002686 \\
(0.284)\end{array}$ & $\begin{array}{r}0.086740 \\
(0.521)\end{array}$ \\
\hline Job dummy 2 & $\begin{array}{r}-0.000014 \\
(0.951)\end{array}$ & $\begin{array}{r}-0.000023 \\
(0.921)\end{array}$ & $\begin{array}{r}-0.000039 \\
(0.858)\end{array}$ & $\begin{array}{r}-0.000127 \\
(0.521)\end{array}$ & $\begin{array}{r}0.000402 \\
(0.989)\end{array}$ & $\begin{array}{r}0.025703 \\
(0.170)\end{array}$ & $\begin{array}{r}0.015622 \\
(0.538)\end{array}$ & $\begin{array}{r}0.825745 \\
(0.169)\end{array}$ & $\begin{array}{r}-0.000572 \\
(0.881)\end{array}$ & $\begin{array}{r}-0.162275 \\
(0.286)\end{array}$ \\
\hline Job dummy3 & $\begin{array}{r}0.000032 \\
(0.866)\end{array}$ & $\begin{array}{r}0.000037 \\
(0.849)\end{array}$ & $\begin{array}{r}0.000057 \\
(0.755)\end{array}$ & $\begin{array}{r}-0.000033 \\
(0.833)\end{array}$ & $\begin{array}{r}0.006324 \\
(0.797)\end{array}$ & $\begin{array}{r}0.014872 \\
(0.287)\end{array}$ & $\begin{array}{r}0.016910 \\
(0.407)\end{array}$ & $\begin{array}{r}-0.306398 \\
(0.269)\end{array}$ & $\begin{array}{r}-0.004121^{*} \\
(0.090)\end{array}$ & $\begin{array}{r}-0.008389 \\
(0.948)\end{array}$ \\
\hline Job dummy4 & $\begin{array}{r}-0.000375 \\
(0.127)\end{array}$ & $\begin{array}{r}-0.000375 \\
(0.135)\end{array}$ & $\begin{array}{r}-0.000416 \\
(0.134)\end{array}$ & $\begin{array}{r}-0.000460^{*} \\
(0.072)\end{array}$ & $\begin{array}{r}-0.090405^{*} \\
(0.070)\end{array}$ & $\begin{array}{r}0.014012 \\
(0.357)\end{array}$ & $\begin{array}{r}0.019720 \\
(0.355)\end{array}$ & $\begin{array}{r}-0.229090 \\
(0.393)\end{array}$ & $\begin{array}{r}-0.003020 \\
(0.222)\end{array}$ & $\begin{array}{r}-0.035912 \\
(0.789)\end{array}$ \\
\hline Constant & $\begin{array}{r}0.000579 \\
(0.332) \\
\end{array}$ & $\begin{array}{r}0.000598 \\
(0.328) \\
\end{array}$ & $\begin{array}{r}0.001580^{* * *} \\
(0.020) \\
\end{array}$ & $\begin{array}{r}0.001502 * * \\
(0.025) \\
\end{array}$ & $\begin{array}{r}0.172354 \\
(0.198) \\
\end{array}$ & $\begin{array}{r}-0.022041 \\
(0.593) \\
\end{array}$ & $\begin{array}{r}0.046420 \\
(0.333) \\
\end{array}$ & $\begin{array}{r}0.857456 \\
(0.243) \\
\end{array}$ & $\begin{array}{r}0.008168^{*} \\
(0.058) \\
\end{array}$ & $\begin{array}{r}-0.278317 \\
(0.354) \\
\end{array}$ \\
\hline Observations & 3,032 & 3,032 & 3,032 & 3,032 & 3,032 & 3,032 & 3,032 & 3,032 & 3,032 & 3,032 \\
\hline R-squared & 0.007 & 0.007 & 0.007 & 0.007 & 0.007 & 0.013 & 0.008 & 0.010 & 0.010 & 0.005 \\
\hline
\end{tabular}




\section{Table 15: Effect of reports, by expectation of subscribing (18 months after first distribution)}

This table displays the results for the difference-in-differences analysis from August 2013 to end of January 2015 (18 months). Panel A focusses on those investors who were expected to subscribe, and panel B uses investors who were not expected to do so. The columns (1) to (5) measure changes in portfolio performance, columns (6) and (7) changes in diversification, and columns (8) and (9)

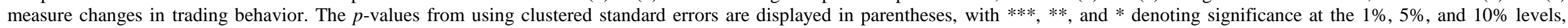
respectively. The line $\mathrm{p}$-value of difference reports a test for differences in coefficient estimates using seemingly unrelated regressions.

\begin{tabular}{|c|c|c|c|c|c|c|c|c|c|c|}
\hline \multirow[b]{3}{*}{ Variables } & \multicolumn{5}{|c|}{ Return / Performance } & \multicolumn{2}{|c|}{ Diversification } & \multicolumn{2}{|c|}{ Trading } & \multirow{2}{*}{$\begin{array}{c}\text { Investment } \\
(10) \\
\end{array}$} \\
\hline & $(1)$ & $(2)$ & (3) & (4) & $(5)$ & $(6)$ & $(7)$ & $(8)$ & (9) & \\
\hline & Return & Net- Return & $\begin{array}{c}\text { Alpha (gross) } \\
\text { (1-factor) }\end{array}$ & $\begin{array}{c}\text { Alpha (gross) } \\
\text { (4-factor) }\end{array}$ & Sharpe Ratio & $\begin{array}{c}\text { Unsys. var. } \\
\text { (4-factor) }\end{array}$ & HHI & Fees & Turnover & Size of portfolio \\
\hline \multicolumn{11}{|c|}{ PANEL A: EXPECTED TO SUBSCRIBE } \\
\hline Report & $\begin{array}{r}0.000535^{* * * *} \\
(0.001)\end{array}$ & $\begin{array}{r}0.000566^{* * * *} \\
(0.001)\end{array}$ & $\begin{array}{r}0.000442 * * \\
(0.017)\end{array}$ & $\begin{array}{r}0.000441^{* *} \\
(0.018)\end{array}$ & $\begin{array}{r}0.065759 * * \\
(0.012)\end{array}$ & $\begin{array}{r}-0.045996^{* * * *} \\
(0.002)\end{array}$ & $\begin{array}{r}0.000528 \\
(0.971)\end{array}$ & $\begin{array}{r}-0.423664 \\
(0.150)\end{array}$ & $\begin{array}{r}-0.002496 \text { **** } \\
(0.005)\end{array}$ & $\begin{array}{r}-0.009542 \\
(0.923)\end{array}$ \\
\hline \multicolumn{11}{|c|}{ PANEL B: NOT EXPECTED TO SUBSCRIBE } \\
\hline Report & $\begin{array}{r}0.000416^{* *} \\
(0.049) \\
\end{array}$ & $\begin{array}{r}0.000437 * * \\
(0.044) \\
\end{array}$ & $\begin{array}{r}0.000318^{*} \\
(0.094) \\
\end{array}$ & $\begin{array}{r}0.000345^{*} \\
(0.069) \\
\end{array}$ & $\begin{array}{r}0.066446 * \\
(0.060) \\
\end{array}$ & $\begin{array}{r}-0.014749^{*} \\
(0.071) \\
\end{array}$ & $\begin{array}{r}-0.028897 * * * \\
(0.008) \\
\end{array}$ & $\begin{array}{r}-0.016583 \\
(0.915) \\
\end{array}$ & $\begin{array}{r}-0.002937 * * * \\
(0.005) \\
\end{array}$ & $\begin{array}{r}0.083659 \\
(0.206) \\
\end{array}$ \\
\hline P-value of difference & 0.655 & 0.636 & 0.640 & 0.714 & 0.987 & 0.067 & 0.100 & 0.218 & 0.747 & 0.431 \\
\hline
\end{tabular}




\section{Table 16: Effect of reports for users with subscription dummy (18 months after first distribution)}

This table displays the results for the difference-in-differences analysis from August 2013 to end of January 2015 (18 months). In this table, we only use investors who subscribe to the reporting service. We include a dummy variable subscription expected which is set to one if this investors was expected to subscribe based on the estimates from table 3 . The columns (1) to (5) measure changes in portfolio performance, columns (6) and (7) changes in diversification, and columns (8) and (9) measure changes in trading behavior. The $p$-values from using clustered standard errors are displayed in parentheses, with $* * *, * *$, and $*$ denoting significance at the $1 \%, 5 \%$, and $10 \%$ levels, respectively.

\begin{tabular}{|c|c|c|c|c|c|c|c|c|c|c|}
\hline \multirow[b]{3}{*}{ Variables } & \multicolumn{5}{|c|}{ Return / Performance } & \multicolumn{2}{|c|}{ Diversification } & \multicolumn{2}{|c|}{ Trading } & \multirow{2}{*}{$\begin{array}{c}\text { Investment } \\
(10) \\
\end{array}$} \\
\hline & $(1)$ & (2) & (3) & (4) & $(5)$ & (6) & (7) & (8) & (9) & \\
\hline & Return & Net- Return & $\begin{array}{c}\text { Alpha (gross) } \\
\text { (1-factor) }\end{array}$ & $\begin{array}{c}\text { Alpha (gross) } \\
\text { (4-factor) }\end{array}$ & Sharpe Ratio & $\begin{array}{l}\text { Unsys. var. } \\
\text { (4-factor) }\end{array}$ & HHI & Fees & Turnover & Size of portfolio \\
\hline Subscription expected & $\begin{array}{r}0.000190 \\
(0.559)\end{array}$ & $\begin{array}{r}0.000185 \\
(0.570)\end{array}$ & $\begin{array}{r}-0.000084 \\
(0.809)\end{array}$ & $\begin{array}{r}-0.000100 \\
(0.768)\end{array}$ & $\begin{array}{r}0.000521 \\
(0.993)\end{array}$ & $\begin{array}{r}0.013478 \\
(0.351)\end{array}$ & $\begin{array}{r}0.059313^{* * * *} \\
(0.005)\end{array}$ & $\begin{array}{r}-0.029348 \\
(0.815)\end{array}$ & $\begin{array}{r}0.000176 \\
(0.891)\end{array}$ & $\begin{array}{r}0.219909^{*} \\
(0.068)\end{array}$ \\
\hline Age & $\begin{array}{r}0.000040 \\
(0.453)\end{array}$ & $\begin{array}{r}0.000040 \\
(0.455)\end{array}$ & $\begin{array}{r}0.000012 \\
(0.829)\end{array}$ & $\begin{array}{r}0.000013 \\
(0.796)\end{array}$ & $\begin{array}{r}0.004310 \\
(0.652)\end{array}$ & $\begin{array}{r}0.001288 \\
(0.610)\end{array}$ & $\begin{array}{r}0.002518 \\
(0.482)\end{array}$ & $\begin{array}{r}-0.025439 \\
(0.412)\end{array}$ & $\begin{array}{r}-0.000312 \\
(0.241)\end{array}$ & $\begin{array}{r}0.040284 * \\
(0.057)\end{array}$ \\
\hline $\operatorname{Age}^{\wedge} 2$ & $\begin{array}{r}-0.000000 \\
(0.493)\end{array}$ & $\begin{array}{r}-0.000000 \\
(0.484)\end{array}$ & $\begin{array}{r}-0.000000 \\
(0.761)\end{array}$ & $\begin{array}{r}-0.000000 \\
(0.741)\end{array}$ & $\begin{array}{r}-0.000044 \\
(0.573)\end{array}$ & $\begin{array}{r}-0.000017 \\
(0.497)\end{array}$ & $\begin{array}{r}-0.000028 \\
(0.385)\end{array}$ & $\begin{array}{r}0.000285 \\
(0.354)\end{array}$ & $\begin{array}{r}0.000003 \\
(0.243)\end{array}$ & $\begin{array}{r}-0.000363^{*} \\
(0.075)\end{array}$ \\
\hline Gender & $\begin{array}{r}0.000104 \\
(0.551)\end{array}$ & $\begin{array}{r}0.000122 \\
(0.503)\end{array}$ & $\begin{array}{r}0.000122 \\
(0.490)\end{array}$ & $\begin{array}{r}0.000124 \\
(0.455)\end{array}$ & $\begin{array}{r}0.017518 \\
(0.485)\end{array}$ & $\begin{array}{r}-0.005654 \\
(0.733)\end{array}$ & $\begin{array}{r}-0.011800 \\
(0.593)\end{array}$ & $\begin{array}{r}-0.221382 \\
(0.466)\end{array}$ & $\begin{array}{r}0.005361 \\
(0.108)\end{array}$ & $\begin{array}{r}-0.060366 \\
(0.641)\end{array}$ \\
\hline Risk-class (WpHG) & $\begin{array}{r}-0.000062 \\
(0.456)\end{array}$ & $\begin{array}{r}-0.000057 \\
(0.493)\end{array}$ & $\begin{array}{r}-0.000107 \\
(0.173)\end{array}$ & $\begin{array}{r}-0.000081 \\
(0.289)\end{array}$ & $\begin{array}{r}-0.010334 \\
(0.409)\end{array}$ & $\begin{array}{r}0.005556 \\
(0.404)\end{array}$ & $\begin{array}{r}-0.000783 \\
(0.927)\end{array}$ & $\begin{array}{r}0.018200 \\
(0.836)\end{array}$ & $\begin{array}{r}-0.000395 \\
(0.656)\end{array}$ & $\begin{array}{r}0.004559 \\
(0.920)\end{array}$ \\
\hline Number of portfolios & $\begin{array}{r}0.000022 \\
(0.707)\end{array}$ & $\begin{array}{r}0.000022 \\
(0.708)\end{array}$ & $\begin{array}{r}0.000062 \\
(0.297)\end{array}$ & $\begin{array}{r}0.000058 \\
(0.315)\end{array}$ & $\begin{array}{r}0.010748 \\
(0.198)\end{array}$ & $\begin{array}{r}0.009328 \\
(0.145)\end{array}$ & $\begin{array}{r}-0.002804 \\
(0.726)\end{array}$ & $\begin{array}{r}-0.194980^{* *} \\
(0.014)\end{array}$ & $\begin{array}{r}0.000504 \\
(0.517)\end{array}$ & $\begin{array}{r}-0.032563 \\
(0.517)\end{array}$ \\
\hline Portfolio size (July 2013) & $\begin{array}{r}0.000000 \\
(0.805)\end{array}$ & $\begin{array}{r}0.000000 \\
(0.847)\end{array}$ & $\begin{array}{r}0.000000 \\
(0.690)\end{array}$ & $\begin{array}{r}-0.000000 \\
(0.937)\end{array}$ & $\begin{array}{r}0.000000 \\
(0.558)\end{array}$ & $\begin{array}{r}0.000000^{* * * *} \\
(0.000)\end{array}$ & $\begin{array}{r}0.000000 \\
(0.173)\end{array}$ & $\begin{array}{r}0.000002 * \\
(0.059)\end{array}$ & $\begin{array}{r}0.000000^{* *} \\
(0.039)\end{array}$ & $\begin{array}{r}0.000000 \\
(0.155)\end{array}$ \\
\hline Job dummy1 & $\begin{array}{r}-0.000098 \\
(0.594)\end{array}$ & $\begin{array}{r}-0.000109 \\
(0.555)\end{array}$ & $\begin{array}{r}-0.000094 \\
(0.589)\end{array}$ & $\begin{array}{r}-0.000120 \\
(0.496)\end{array}$ & $\begin{array}{r}-0.011094 \\
(0.632)\end{array}$ & $\begin{array}{r}-0.005787 \\
(0.788)\end{array}$ & $\begin{array}{r}0.015928 \\
(0.600)\end{array}$ & $\begin{array}{r}-0.499189 \\
(0.263)\end{array}$ & $\begin{array}{r}-0.005658 \\
(0.106)\end{array}$ & $\begin{array}{r}-0.250968 \\
(0.170)\end{array}$ \\
\hline Job dummy 2 & $\begin{array}{r}-0.000110 \\
(0.678)\end{array}$ & $\begin{array}{r}-0.000124 \\
(0.641)\end{array}$ & $\begin{array}{r}-0.000124 \\
(0.624)\end{array}$ & $\begin{array}{r}-0.000133 \\
(0.604)\end{array}$ & $\begin{array}{r}-0.026982 \\
(0.384)\end{array}$ & $\begin{array}{r}0.013317 \\
(0.612)\end{array}$ & $\begin{array}{r}0.023003 \\
(0.527)\end{array}$ & $\begin{array}{r}-0.253058 \\
(0.629)\end{array}$ & $\begin{array}{r}-0.009440 * \\
(0.055)\end{array}$ & $\begin{array}{r}-0.559864 * * * \\
(0.007)\end{array}$ \\
\hline Job dummy3 & $\begin{array}{r}-0.000110 \\
(0.539)\end{array}$ & $\begin{array}{r}-0.000132 \\
(0.464)\end{array}$ & $\begin{array}{r}-0.000070 \\
(0.684)\end{array}$ & $\begin{array}{r}-0.000087 \\
(0.615)\end{array}$ & $\begin{array}{r}-0.014761 \\
(0.528)\end{array}$ & $\begin{array}{r}0.008430 \\
(0.659)\end{array}$ & $\begin{array}{r}0.007198 \\
(0.802)\end{array}$ & $\begin{array}{r}-0.811988^{*} \\
(0.060)\end{array}$ & $\begin{array}{r}-0.007700^{* *} \\
(0.032)\end{array}$ & $\begin{array}{r}-0.252007 \\
(0.143)\end{array}$ \\
\hline Job dummy 4 & $\begin{array}{r}-0.000457 \\
(0.133)\end{array}$ & $\begin{array}{r}-0.000464 \\
(0.129)\end{array}$ & $\begin{array}{r}-0.000438 \\
(0.135)\end{array}$ & $\begin{array}{r}-0.000427 \\
(0.140)\end{array}$ & $\begin{array}{r}-0.070160 \\
(0.138)\end{array}$ & $\begin{array}{r}0.007886 \\
(0.708)\end{array}$ & $\begin{array}{r}0.018190 \\
(0.560)\end{array}$ & $\begin{array}{r}-0.645439 \\
(0.128)\end{array}$ & $\begin{array}{r}-0.007111^{* *} \\
(0.047)\end{array}$ & $\begin{array}{r}-0.371509 * * \\
(0.047)\end{array}$ \\
\hline Constant & $\begin{array}{r}-0.001000 \\
(0.398) \\
\end{array}$ & $\begin{array}{r}-0.000993 \\
(0.404) \\
\end{array}$ & $\begin{array}{r}0.000483 \\
(0.693)\end{array}$ & $\begin{array}{r}0.000406 \\
(0.735) \\
\end{array}$ & $\begin{array}{r}-0.084662 \\
(0.689)\end{array}$ & $\begin{array}{r}-0.126602 * \\
(0.088)\end{array}$ & $\begin{array}{r}-0.057538 \\
(0.560)\end{array}$ & $\begin{array}{r}1.589129 \\
(0.132) \\
\end{array}$ & $\begin{array}{r}0.010313 \\
(0.282) \\
\end{array}$ & $\begin{array}{r}-0.225841 \\
(0.690) \\
\end{array}$ \\
\hline Observations & 1,517 & 1,517 & 1,517 & 1,517 & 1,517 & 1,517 & 1,517 & 1,517 & 1,517 & 1,517 \\
\hline R-squared & 0.005 & 0.005 & 0.006 & 0.005 & 0.006 & 0.011 & 0.014 & 0.038 & 0.013 & 0.013 \\
\hline
\end{tabular}


Table 17: Effect of reports for users with subscription dummy and questionnaire responses (18 months after first distribution)

This table displays the results for the difference-in-differences analysis from August 2013 to end of January 2015 (18 months). In this table, we only use investors who subscribe to the reporting service. We include a dummy variable subscription expected which is set to one if this investors was expected to subscribe based on the estimates from table 3 . We additionally control for information obtained from the questionnaire among subscribers. The columns (1) to (5) measure changes in portfolio performance, columns (6) and (7) changes in diversification, and columns (8) and (9) measure changes in trading behavior. The $p$-values from using clustered standard errors are displayed in parentheses, with ***,**, and * denoting significance at the $1 \%, 5 \%$, and $10 \%$ levels, respectively.

\begin{tabular}{|c|c|c|c|c|c|c|c|c|c|c|}
\hline \multirow[b]{3}{*}{ Variables } & \multicolumn{5}{|c|}{ Return / Performance } & \multicolumn{2}{|c|}{ Diversification } & \multicolumn{2}{|c|}{ Trading } & \multirow{2}{*}{$\begin{array}{c}\text { Investment } \\
(10)\end{array}$} \\
\hline & (1) & (2) & (3) & (4) & (5) & (6) & (7) & (8) & (9) & \\
\hline & Return & Net- Return & $\begin{array}{c}\text { Alpha (gross) } \\
\text { (1-factor) }\end{array}$ & $\begin{array}{c}\text { Alpha (gross) } \\
\text { (4-factor) }\end{array}$ & Sharpe Ratio & $\begin{array}{l}\text { Unsys. var. } \\
\text { (4-factor) }\end{array}$ & HHI & Fees & Turnover & Size of portfolio \\
\hline Subscription expected & $\begin{array}{r}0.000166 \\
(0.610)\end{array}$ & $\begin{array}{r}0.000162 \\
(0.620)\end{array}$ & $\begin{array}{r}-0.000098 \\
(0.775)\end{array}$ & $\begin{array}{r}-0.000114 \\
(0.735)\end{array}$ & $\begin{array}{r}-0.002119 \\
(0.971)\end{array}$ & $\begin{array}{r}0.012946 \\
(0.380)\end{array}$ & $\begin{array}{r}0.060036^{* * * *} \\
(0.005)\end{array}$ & $\begin{array}{r}-0.016675 \\
(0.897)\end{array}$ & $\begin{array}{r}0.000078 \\
(0.950)\end{array}$ & $\begin{array}{r}0.172873 \\
(0.146)\end{array}$ \\
\hline Dummy avail. time & $\begin{array}{r}0.000134 \\
(0.540)\end{array}$ & $\begin{array}{r}0.000134 \\
(0.540)\end{array}$ & $\begin{array}{r}0.000021 \\
(0.923)\end{array}$ & $\begin{array}{r}0.000034 \\
(0.878)\end{array}$ & $\begin{array}{r}-0.003847 \\
(0.884)\end{array}$ & $\begin{array}{r}0.009822 \\
(0.501)\end{array}$ & $\begin{array}{r}-0.001001 \\
(0.959)\end{array}$ & $\begin{array}{r}0.026914 \\
(0.845)\end{array}$ & $\begin{array}{r}-0.001409 \\
(0.208)\end{array}$ & $\begin{array}{r}-0.120606 \\
(0.202)\end{array}$ \\
\hline Trust & $\begin{array}{r}0.000093 \\
(0.484)\end{array}$ & $\begin{array}{r}0.000096 \\
(0.483)\end{array}$ & $\begin{array}{r}0.000104 \\
(0.437)\end{array}$ & $\begin{array}{r}0.000097 \\
(0.481)\end{array}$ & $\begin{array}{r}0.021250 \\
(0.233)\end{array}$ & $\begin{array}{r}0.012140 \\
(0.259)\end{array}$ & $\begin{array}{r}-0.004419 \\
(0.747)\end{array}$ & $\begin{array}{r}-0.143108 \\
(0.321)\end{array}$ & $\begin{array}{r}-0.000974 \\
(0.408)\end{array}$ & $\begin{array}{r}-0.015477 \\
(0.846)\end{array}$ \\
\hline Financial literacy & $\begin{array}{r}0.000036 \\
(0.747)\end{array}$ & $\begin{array}{r}0.000037 \\
(0.743)\end{array}$ & $\begin{array}{r}0.000055 \\
(0.590)\end{array}$ & $\begin{array}{r}0.000047 \\
(0.636)\end{array}$ & $\begin{array}{r}0.011914 \\
(0.505)\end{array}$ & $\begin{array}{r}-0.001906 \\
(0.698)\end{array}$ & $\begin{array}{r}0.002475 \\
(0.672)\end{array}$ & $\begin{array}{r}0.147119^{*} \\
(0.090)\end{array}$ & $\begin{array}{r}0.001278^{* *} \\
(0.032)\end{array}$ & $\begin{array}{r}0.081415^{* * *} \\
(0.022)\end{array}$ \\
\hline Optimism & $\begin{array}{r}-0.000007^{*} \\
(0.065)\end{array}$ & $\begin{array}{r}-0.000007^{*} \\
(0.089)\end{array}$ & $\begin{array}{r}-0.000006 \\
(0.157)\end{array}$ & $\begin{array}{r}-0.000006 \\
(0.180)\end{array}$ & $\begin{array}{r}-0.000955^{*} \\
(0.065)\end{array}$ & $\begin{array}{r}0.000977^{* *} \\
(0.017)\end{array}$ & $\begin{array}{r}0.000457 \\
(0.451)\end{array}$ & $\begin{array}{r}0.001364 \\
(0.663)\end{array}$ & $\begin{array}{r}0.000042 \\
(0.524)\end{array}$ & $\begin{array}{r}-0.004244 \\
(0.154)\end{array}$ \\
\hline Long-term investor & $\begin{array}{r}0.000095 \\
(0.513)\end{array}$ & $\begin{array}{r}0.000091 \\
(0.535)\end{array}$ & $\begin{array}{r}-0.000031 \\
(0.827)\end{array}$ & $\begin{array}{r}-0.000015 \\
(0.917)\end{array}$ & $\begin{array}{r}-0.011683 \\
(0.608)\end{array}$ & $\begin{array}{r}0.002017 \\
(0.851)\end{array}$ & $\begin{array}{r}-0.003457 \\
(0.796)\end{array}$ & $\begin{array}{r}-0.105397 \\
(0.495)\end{array}$ & $\begin{array}{r}-0.000186 \\
(0.880)\end{array}$ & $\begin{array}{r}0.214227 * * * * \\
(0.005)\end{array}$ \\
\hline Age & $\begin{array}{r}0.000035 \\
(0.484)\end{array}$ & $\begin{array}{r}0.000035 \\
(0.487)\end{array}$ & $\begin{array}{r}0.000008 \\
(0.873)\end{array}$ & $\begin{array}{r}0.000010 \\
(0.837)\end{array}$ & $\begin{array}{r}0.003620 \\
(0.688)\end{array}$ & $\begin{array}{r}0.001186 \\
(0.644)\end{array}$ & $\begin{array}{r}0.002500 \\
(0.490)\end{array}$ & $\begin{array}{r}-0.028941 \\
(0.365)\end{array}$ & $\begin{array}{r}-0.000377 \\
(0.171)\end{array}$ & $\begin{array}{r}0.030040 \\
(0.157)\end{array}$ \\
\hline $\operatorname{Age}^{\wedge} 2$ & $\begin{array}{r}-0.000000 \\
(0.540)\end{array}$ & $\begin{array}{r}-0.000000 \\
(0.529)\end{array}$ & $\begin{array}{r}-0.000000 \\
(0.825)\end{array}$ & $\begin{array}{r}-0.000000 \\
(0.800)\end{array}$ & $\begin{array}{r}-0.000035 \\
(0.624)\end{array}$ & $\begin{array}{r}-0.000017 \\
(0.493)\end{array}$ & $\begin{array}{r}-0.000028 \\
(0.390)\end{array}$ & $\begin{array}{r}0.000330 \\
(0.292)\end{array}$ & $\begin{array}{r}0.000004 \\
(0.164)\end{array}$ & $\begin{array}{r}-0.000251 \\
(0.221)\end{array}$ \\
\hline Gender & $\begin{array}{r}0.000095 \\
(0.602)\end{array}$ & $\begin{array}{r}0.000113 \\
(0.549)\end{array}$ & $\begin{array}{r}0.000109 \\
(0.548)\end{array}$ & $\begin{array}{r}0.000113 \\
(0.509)\end{array}$ & $\begin{array}{r}0.015089 \\
(0.564)\end{array}$ & $\begin{array}{r}-0.003524 \\
(0.830)\end{array}$ & $\begin{array}{r}-0.011916 \\
(0.588)\end{array}$ & $\begin{array}{r}-0.257977 \\
(0.392)\end{array}$ & $\begin{array}{r}0.005300 \\
(0.118)\end{array}$ & $\begin{array}{r}-0.046834 \\
(0.717)\end{array}$ \\
\hline Risk-class (WpHG) & $\begin{array}{r}-0.000073 \\
(0.433)\end{array}$ & $\begin{array}{r}-0.000069 \\
(0.465)\end{array}$ & $\begin{array}{r}-0.000113 \\
(0.197)\end{array}$ & $\begin{array}{r}-0.000088 \\
(0.311)\end{array}$ & $\begin{array}{r}-0.011081 \\
(0.416)\end{array}$ & $\begin{array}{r}0.005306 \\
(0.430)\end{array}$ & $\begin{array}{r}-0.000889 \\
(0.920)\end{array}$ & $\begin{array}{r}0.003749 \\
(0.967)\end{array}$ & $\begin{array}{r}-0.000398 \\
(0.658)\end{array}$ & $\begin{array}{r}0.007723 \\
(0.866)\end{array}$ \\
\hline Number of portfolios & $\begin{array}{r}0.000011 \\
(0.855)\end{array}$ & $\begin{array}{r}0.000012 \\
(0.846)\end{array}$ & $\begin{array}{r}0.000061 \\
(0.303)\end{array}$ & $\begin{array}{r}0.000057 \\
(0.330)\end{array}$ & $\begin{array}{r}0.011149 \\
(0.182)\end{array}$ & $\begin{array}{r}0.010053 \\
(0.115)\end{array}$ & $\begin{array}{r}-0.002555 \\
(0.749)\end{array}$ & $\begin{array}{r}-0.198627 * * * \\
(0.015)\end{array}$ & $\begin{array}{r}0.000462 \\
(0.557)\end{array}$ & $\begin{array}{r}-0.053542 \\
(0.270)\end{array}$ \\
\hline Portfolio size (July 2013) & $\begin{array}{r}-0.000000 \\
(0.962)\end{array}$ & $\begin{array}{r}-0.000000 \\
(0.929)\end{array}$ & $\begin{array}{r}0.000000 \\
(0.890)\end{array}$ & $\begin{array}{r}-0.000000 \\
(0.763)\end{array}$ & $\begin{array}{r}0.000000 \\
(0.823)\end{array}$ & $\begin{array}{r}0.000000^{* * *} \\
(0.000)\end{array}$ & $\begin{array}{r}0.000000 \\
(0.168)\end{array}$ & $\begin{array}{r}0.000002^{*} \\
(0.069)\end{array}$ & $\begin{array}{r}0.000000^{*} \\
(0.076)\end{array}$ & $\begin{array}{r}0.000000 \\
(0.239)\end{array}$ \\
\hline Job dummy1 & $\begin{array}{r}-0.000106 \\
(0.570)\end{array}$ & $\begin{array}{r}-0.000114 \\
(0.540)\end{array}$ & $\begin{array}{r}-0.000101 \\
(0.571)\end{array}$ & $\begin{array}{r}-0.000126 \\
(0.483)\end{array}$ & $\begin{array}{r}-0.012375 \\
(0.605)\end{array}$ & $\begin{array}{r}-0.002917 \\
(0.892)\end{array}$ & $\begin{array}{r}0.016635 \\
(0.586)\end{array}$ & $\begin{array}{r}-0.501046 \\
(0.258)\end{array}$ & $\begin{array}{r}-0.005719 \\
(0.106)\end{array}$ & $\begin{array}{r}-0.274833 \\
(0.133)\end{array}$ \\
\hline Job dummy 2 & $\begin{array}{r}-0.000132 \\
(0.621)\end{array}$ & $\begin{array}{r}-0.000142 \\
(0.595)\end{array}$ & $\begin{array}{r}-0.000144 \\
(0.574)\end{array}$ & $\begin{array}{r}-0.000152 \\
(0.557)\end{array}$ & $\begin{array}{r}-0.030403 \\
(0.336)\end{array}$ & $\begin{array}{r}0.020142 \\
(0.449)\end{array}$ & $\begin{array}{r}0.024790 \\
(0.502)\end{array}$ & $\begin{array}{r}-0.264839 \\
(0.616)\end{array}$ & $\begin{array}{r}-0.009361^{*} \\
(0.062)\end{array}$ & $\begin{array}{r}-0.577226^{* * *} \\
(0.006)\end{array}$ \\
\hline Job dummy 3 & $\begin{array}{r}-0.000106 \\
(0.560)\end{array}$ & $\begin{array}{r}-0.000127 \\
(0.490)\end{array}$ & $\begin{array}{r}-0.000073 \\
(0.676)\end{array}$ & $\begin{array}{r}-0.000089 \\
(0.614)\end{array}$ & $\begin{array}{r}-0.015816 \\
(0.513)\end{array}$ & $\begin{array}{r}0.011632 \\
(0.547)\end{array}$ & $\begin{array}{r}0.007201 \\
(0.804)\end{array}$ & $\begin{array}{r}-0.831739^{*} \\
(0.055)\end{array}$ & $\begin{array}{r}-0.007934^{* *} \\
(0.030)\end{array}$ & $\begin{array}{r}-0.274840 \\
(0.111)\end{array}$ \\
\hline Job dummy4 & $\begin{array}{r}-0.000454 \\
(0.125)\end{array}$ & $\begin{array}{r}-0.000460 \\
(0.123)\end{array}$ & $\begin{array}{r}-0.000440 \\
(0.126)\end{array}$ & $\begin{array}{r}-0.000428 \\
(0.130)\end{array}$ & $\begin{array}{r}-0.070650 \\
(0.131)\end{array}$ & $\begin{array}{r}0.012035 \\
(0.573)\end{array}$ & $\begin{array}{r}0.019213 \\
(0.543)\end{array}$ & $\begin{array}{r}-0.638168 \\
(0.134)\end{array}$ & $\begin{array}{r}-0.007041^{*} \\
(0.056)\end{array}$ & $\begin{array}{r}-0.378235^{* *} * \\
(0.043)\end{array}$ \\
\hline Constant & $\begin{array}{r}-0.001149 \\
(0.369) \\
\end{array}$ & $\begin{array}{r}-0.001144 \\
(0.373) \\
\end{array}$ & $\begin{array}{r}0.000382 \\
(0.773) \\
\end{array}$ & $\begin{array}{r}0.000307 \\
(0.813) \\
\end{array}$ & $\begin{array}{r}-0.101230 \\
(0.658) \\
\end{array}$ & $\begin{array}{r}-0.132468^{*} \\
(0.080) \\
\end{array}$ & $\begin{array}{r}-0.059548 \\
(0.550) \\
\end{array}$ & $\begin{array}{r}1.399057 \\
(0.186) \\
\end{array}$ & $\begin{array}{r}0.009608 \\
(0.312) \\
\end{array}$ & $\begin{array}{r}-0.266247 \\
(0.639) \\
\end{array}$ \\
\hline Observation & 1,517 & 1,517 & 1,517 & 1,517 & 1,517 & 1,517 & 1,517 & 1,517 & 1,517 & 1,517 \\
\hline R-squared & 0.008 & 0.007 & 0.008 & 0.007 & 0.009 & 0.017 & 0.015 & 0.042 & 0.018 & 0.024 \\
\hline
\end{tabular}




\section{For Online Publication: Appendix}

\section{A.1 Detailed motivation for visualizations in the reports}

In non-dynamic settings Paul W. B. Atkins, Robert E. Wood, and Philip J. Rutgers (2002) and Franca Glenzer, Helmut Gründl, and Christian Wilde (2014) show that learning from tabular feedback is greater than from graphical representations. Paul W. B. Atkins, Robert E. Wood, and Philip J. Rutgers (2002), however, also show that in dynamic decision environments graphical displays lead to better performance from feedback. Gordon E. Legge, Yuanchao Gu, and Andrew Luebker (1989) show that information is best extracted from graphs. Furthermore, Ioanna Vekiri (2002) proposes the visualization of information so that it requires only a minimum of cognitive processing, limiting investors' information costs. Furthermore, a graphical display can offer access to information for less numerate readers who are not able to extract it easily from numerical information (Carmen Keller, Michael Siegrist, and Vivianne Visschers 2009). Daniel G. Goldstein, $\begin{array}{lllll}\text { Eric J. Johnson, } & \text { and } & \text { William } & \text { Sharpe }\end{array}$ DanielG.Goldstein,EricJ.Johnson,andWilliamF.Sharpe(2008) also argue that graphical representations help investors choose between alternative probability distributions. In the context of risk communication, Hannah F. Chua, J. F. Yates, and Priti Shah (2006), Christine Kaufmann, Martin Weber, and Emily Haisley (2013) and Franca Glenzer, Helmut Gründl, and Christian Wilde (2014) find that people tend towards the more risky option when confronted with graphic displays instead of numerical information. Therefore, for a reporting of performance, risk and diversification it seems advisable to combine graphical illustrations and labels containing the numerical values.

However, there is large variety of graphical representations available to choose from. Isaac M. Lipkus and J. G. Hollands (1999) propose the use of line graphs to illustrate trends, a suggestion that can be used to display return data over time. Furthermore, simple bar graphs are not suitable to illustrate proportions of change (Justin G. Hollands and Ian Spence 1992) since the significance of potential changes is difficult to assess. Creating reference points, however, might serve as a remedy in this case. For example, showing bar charts of trading costs may not be useful until the total portfolio value or the current year's return is also provided as a reference point. When it comes to estimating the importance of different components it is advisable to spare the viewer the cognitive summation and make the processing of the message as easy as possible (J. G. Hollands and Ian Spence 1998). Divided (stacked) bar graphs and/or pie charts are best for part-to-whole relations, as for example when showing a risk decomposition (Joseph K. H. Tan and Izak Benbasat 1993). 
Besides, personalizing information as much as possible supports information extraction and processing by individual investors (Jeffrey R. Kling et al. 2008). Outcome feedback, i.e. feedback on the status quo or change of a certain measure (e.g. return) has been shown to work in simple, linear environments, but less with regard to complex decisions under uncertainty (Paul J. Hoffman, Timothy C. Earle, and Paul Slovic 1981; William K. Balzer, Michael E. Doherty, and Raymond O'Connor 1989). For these situations, calibration feedback or cognitive feedback (feedback on factors that affect the outcome measure of interest) have proven to be more effective (William K. Balzer et al. 1994). In our context, calibration feedback is equivalent to providing information on factors affecting portfolio returns, i.e. information on costs and risks. Apart from that previous research has shown the effect of peers on investors decisions (Esther Duflo and Emmanuel Saez 2002; Winston R. Sieck and Hal R. Arkes 2005; Dmitry Ryvkin, Marian Krajč, and Andreas Ortmann 2012).

\section{A.2 Process of decision making on report designs}

Based on the above considerations we developed more than 50 different graphical displays for risk, return, and diversification. They were discussed in four focus groups within the faculty and then, in a second stage, with two focus groups of subjects outside the finance or academic area. In preparation of the focus groups ${ }^{12}$ the graphical displays were populated using identical underlying data from a random investor.

In each of the focus groups, participants were divided into two groups of three to five people. Within the groups participants had to discuss all graphical displays and to then select three displays, which fit on one page for their final reports. Focus group participants were asked to summarize what conclusions they drew from the resulting reports. These focus groups gave preference to straightforward graphical displays with numerical labels at relevant places. In a second step, we then gave preference to those displays from which focus group participants seemed to draw conclusions that were commensurate with normative ideas of portfolio management. Finally, participants voiced a strong preference for a short and comprehensive overview of their current investment situation. Therefore, the final format of all securities account reports is limited to one page.

\footnotetext{
${ }^{12}$ Focus groups are prevalently used in social science to discover subjects' hidden needs by bringing them together for an interactive discussion session on a predefined topic, supporting quantitative analyses with qualitative experience reports. Initially known predominantly in marketing research, finance research, as reported by Robert C. Merton (1987), has drawn on further insights gained from this technique early on. For an overview of how to conduct a focus group and major aspects to consider, see Jo-Ellen Asbury (1995).
} 


\section{A.3 Detailed description of individual report designs}

Examples of the four reports are provided in Figure A.1. The "baseline" report adapted from Ralf Gerhardt and Steffen Meyer (2013) starts with a tabular summary of the present account value, the account value 12 months ago, the development of the account value and volatility over the last 12 months in percentage points, gains or losses in Euros, and the portfolio's current risk category on a scale from one to 10. This overview is followed by further graphical presentations in Sections I to III: In the left half of Section I, a risk and return (mu-sigma) diagram displays the performance and volatility of the securities account as well as nine benchmark indices ${ }^{13}$. On the right, a bar chart displays the number of transactions by month over the last year. Below that, in Section II, a line graph shows the return development in Euros over the last 12 months. Finally, in Section III, the month-end balances of the last 13 months are displayed in a bar graph.

The first one (Report Number 2) of the newly designed reports starts with a graphical display of the change in portfolio value over the last 12 months in Section I: A waterfall graph displays how the value of additional investments or disinvestments, gains and losses, as well as the Euro amount of trading costs contribute to the securities account value at the end of the reporting period. The single stacks are labeled with the absolute Euro values they represent and are connected with dotted lines to denote the starting levels of the next stack. Section II shows a line graph displaying the indexed percentage returns of the securities account and of the MSCI All Country World Index, leading to a fan graph displaying the volatility outlook over the next three months. Calculations for the volatility outlook use the portfolio composition as of the closing date and those for the MSCI All Country World Index development during the last 12 months. Section III features a factor analysis (William F. Sharpe 1992). It is visualized using a divided bar graph, which displays the nine international indices also used before on which the current portfolio composition loads. To the right a pie chart shows the share of systematic and unsystematic risk when the portfolio is compared to the MSCI All Country World Index, and an overview of the current risk class, the risk class over the last 12 months, and the stated target risk class.

Report Number 3 is based on Report Number 2 but incorporates additional information of a reference group to contrast the information of the investors' securities account. The peer information is derived from the total sample of investors of the broker whose portfolio volatility over the

\footnotetext{
${ }^{13}$ The benchmark indices are chosen to reflect the development of the stock, bond, commodity and/or foreign exchange markets. For stock markets, we include the MSCI World, the CDAX for the German market, the MSCI USA for the US market, the MSCI Asia for Asian markets. For all equity benchmarks, we use total return indices. Bond markets are tracked using JPM GBI Global all maturities, the IBOXX Euro Corporate all maturity index. We also use total return indices for the bond indices. To track commodity markets we use the Gold Bullion LBMA, and OPEC Oil back price. For foreign exchange exposure we also include the Datastream US-\$ to Euro exchange rate.
} 
preceding twelve months was in a range of +/- two percentage points of the one of the respective investor. To facilitate differentiation between the investor's own account information and peer information we use different color schemes throughout the report. To the right of the waterfall graph displayed in Section I, as described above, a second waterfall displays the same information for the peer group. For better comparison, this peer information is indexed to the starting value of the investor's securities account value at the beginning of the observation period. Similarly, in the return graph (Section II), the indexed percentage portfolio development of the peer group with the same risk level (volatility within a band of $+/-2$ percentage points) for the last 12 months is added to the line graph. In Section III the results from the style analysis are compared to those of a peer group with the same target risk to illustrate the difference in the current risk decomposition (asset allocation). Additionally, the unsystematic risk share of the investor's portfolio is contrasted with that of the peer group. Finally, the report closes with an overview and comparison of the current risk class, the risk class over the last 12 months, as well as the stated target risk class.

Report Number 4 has an additional written summary at the top of the page, with the rest of the report remaining unchanged compared to Report Number 3. The summary is four lines long and condenses the central investment information of the graphical displays below it, namely, the exhibited and targeted risk for the last 12 months with the return achieved, the return of the peer group with the same incurred risk and return achieved; and the risk and return of the MSCI All Country World Index. 


\section{Figure A.1: Examples for the Four Different Securities Account Report Designs}

Report Design Number 1 is similar to the one in Meyer and Gerhardt (2013). Report Designs Number 2-4 build on each other with Number 2 showing information for the investors' securities account only, Number 3 showing information of a peer group with the same risk level, while Number 4 starts with a written summary at the top of the page.

Report Design Number 1

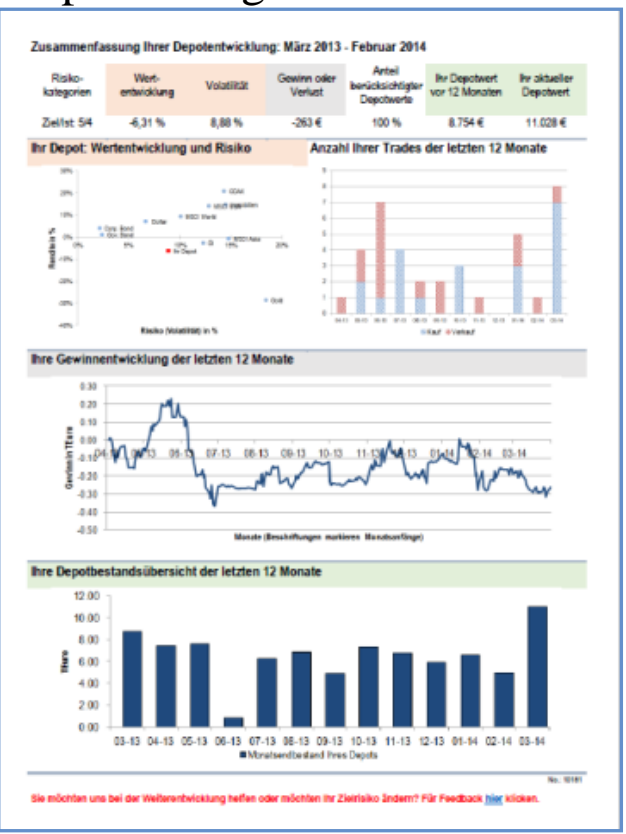

Report Design Number 3

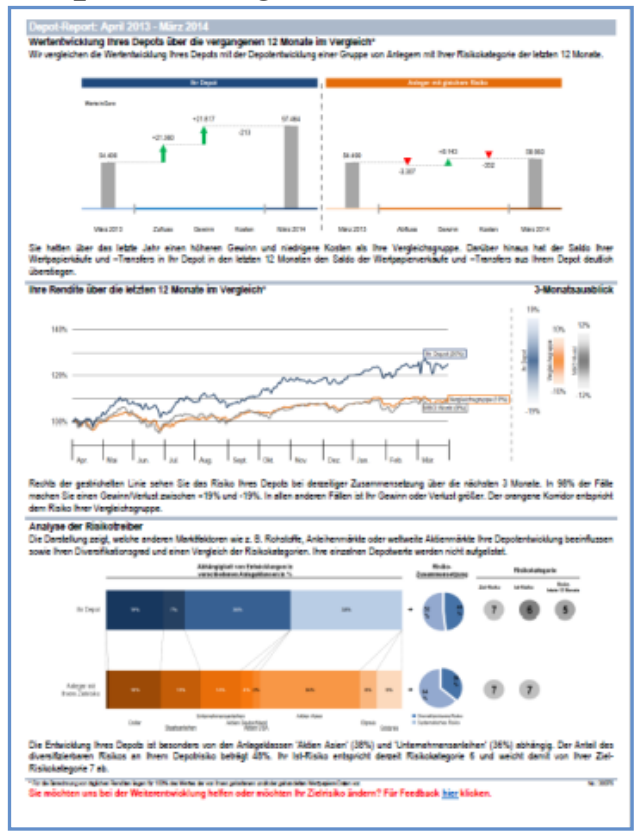

Report Design Number 2

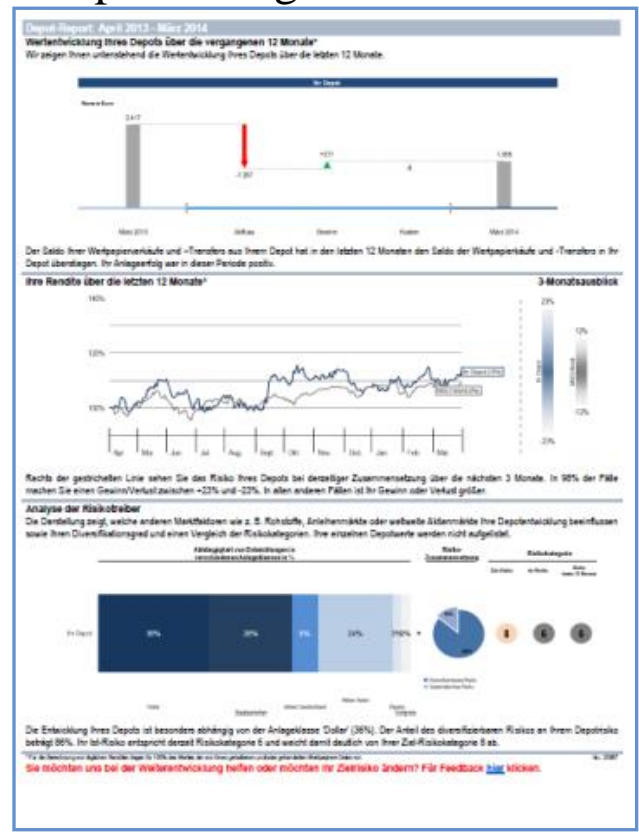

Report Design Number 4

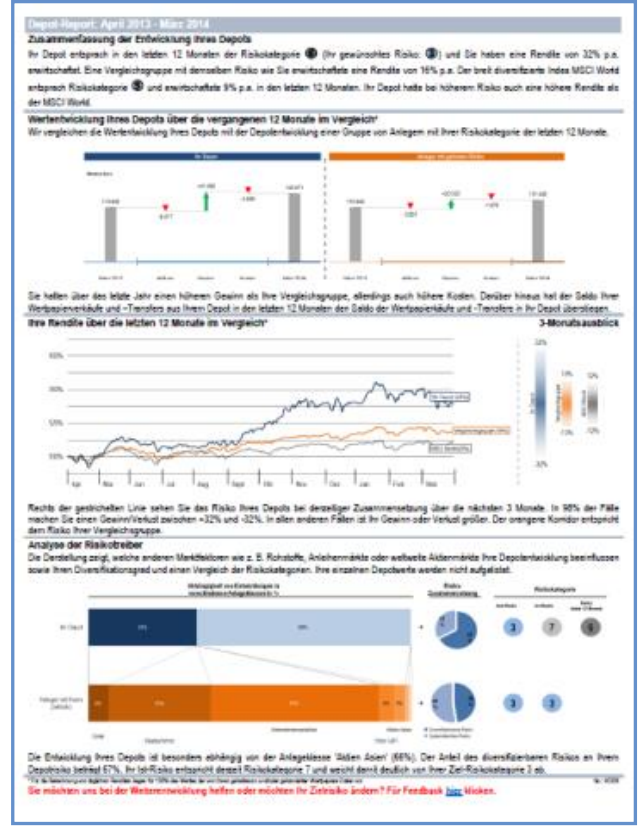




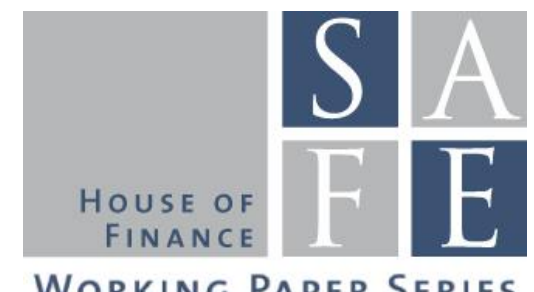

WORKING PAPER SERIES

\section{Recent Issues}

No. 156 Reint Gropp, Thomas Mosk, Steven Ongena, Carlo Wix

No. 155 Vahid Saadi

No. 154 Brigitte Haar

No. 153 Julia Hirsch, Uwe Walz

No. 152 Viral Acharya, Tim Eisert, Christian Eufinger, Christian Hirsch

No. 151 Michael Schneider, Fabrizio Lillo, Loriana Pelizzon

No. 150 Vanya Horneff, Raimond Maurer, Olivia S. Mitchell

No. 149 Massimiliano Caporin, Aleksey Kolokolov, Roberto Renò

No. 148 Sven-Thorsten Jakusch

No. 147 Andreas Hackethal, Sven-Thorsten Jakusch, Steffen Meyer

No. 146 Sven-Thorsten Jakusch, Steffen Meyer, Andreas Hackethal

No. 145 Christian Geppert, Alexander Ludwig, Raphael Abiry
Bank Response To Higher Capital

Requirements: Evidence From A QuasiNatural Experiment

Mortgage Supply and the US Housing Boom: The Role of the Community Reinvestment Act

Shareholder Wealth vs. Stakeholder interests? Evidence from Code Compliance under the German Corporate Governance Code

The Financing Dynamics of Newly Founded Firms

Whatever it Takes: The Real Effects of Unconventional Monetary Policy

How Has Sovereign Bond Markets Liquidity Changed? - An Illiquidity Spillover Analysis

Putting the Pension back in $401(\mathrm{k})$ Plans: Optimal versus Default Longevity Income Annuities

Systemic Co-Jumps

On the Applicability of Maximum Likelihood Methods: From Experimental to Financial Data

Taring all Investors with the same Brush? Evidence for Heterogeneity in Individual Preferences from a Maximum Likelihood Approach

Taming Models of Prospect Theory in the Wild? Estimation of Vlcek and Hens (2011)

Secular Stagnation? Growth, Asset Returns and Welfare in the Next Decades: First Results 